Report on

\title{
Pumpernickel Valley \\ Geothermal Project Thermal Gradient Wells
}

Humboldt County, Nevada

for

Nevada Geothermal Power Inc. Suite 900, 409 Granville Street

Vancouver, B.C., V6C 1T2

and

Inovision Solutions Inc.

Suite 304, 850 Burrard Street

Vancouver, B.C., V6Z 2J1

and

US Department of Energy

Golden Field Office

Office of Program Management

1617 Cole Blvd.

Golden, CO, 80401-3305

GRED III - Phase I

Award No. DE-FG36-04G014340

by

Z. Adam Szybinski, Ph.D.

Fairbank Engineering Ltd.

Suite 901, 409 Granville Street

Vancouver, B.C., Canada, V6C 1T2

January 2006 


\section{TABLE OF CONTENTS}

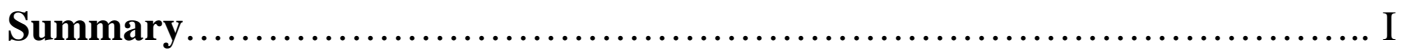

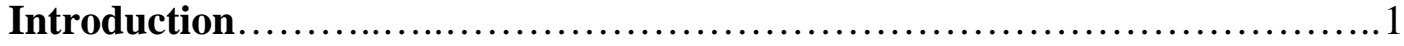

Location, access, physiography and climate..............................

Power transmission facilities......................................................

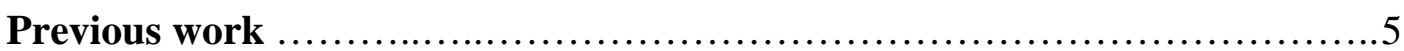

Tectonic setting of the north-central Nevada................................. 6

Geology of the Pumpernickel Valley area..................................... 8

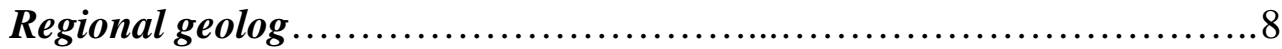

Geology of the project area.............................................

Preble Formation.................................................. 10

Pumpernickel Formation and Havallah Formation..................... 11

Edna Mountain Formation............................................ 11

Younger volcanic, intrusive, and sedimentary rocks.....................11

Quaternary deposits................................................ 11

Structure of the Pumpernickel Valley project area..............................14

Basin and Range tectonism............................................ 15

Major faults...................................................... 16

Pumpernickel Valley geothermal system..................................17

Geothermal features.............................................. 17

Temperature data................................................... 20

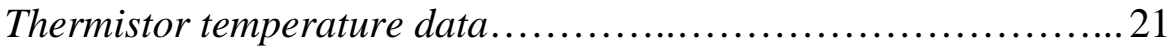

Resistivity survey ................................................... 22

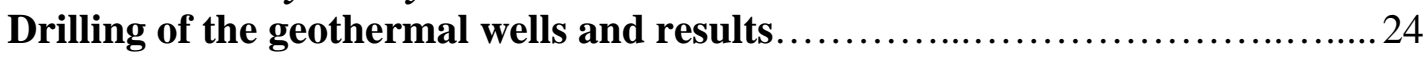

Well site locations.................................................. 24

Drilling equipment and procedures...................................2 27

Logging................................................................ 30

Geology of the drill holes............................................ 31

Temperature data and gradients....................................... 37

Geochemistry................................................. 44

Setting of the Pumpernickel Valley geothermal system........................... 47

Model for the Pumpernickel Valley geothermal field....................................... 48

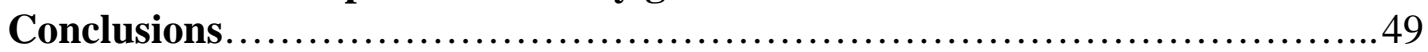

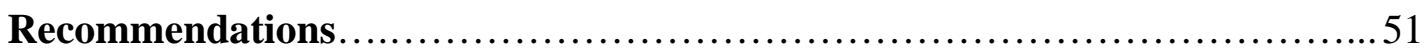

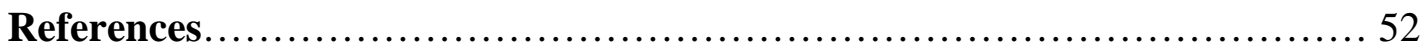




\section{LIST OF FIGURES}

Location of the Pumpernickel Valley project area in Nevada...................................... 2

Typical view of Pumpernickel Valley.............................................. 3

The Pumpernickel Valley project area.............................................4

General map of the Battle Mountain heat flow high....................................

Crustal thicknesses for Nevada................................................... 8

Regional tectonic setting of the project area........................................ 9

Geological map of the Pumpernickel Valley project area.............................. 12

Outcrop of Tertiary ash-flow tuff............................................... 13

Outcrop of boulder-rich Tertiary gravel............................................ 13

Poorly sorted Quaternary gravel.................................................. 14

E-W section of the Preble sequence and Tertiary volcanic rocks........................ 15

Panoramic view of the eastern Sonoma Range and Pumpernickel Valley area.................. 16

Distribution of the hot spring clusters ........................................... 18

Map of the hot spring and Tipton Ranch area....................................... 19

Panoramic view of the Pumpernickel Valley clusters................................. 19

Travertine buildup in the southern cluster of hot springs............................ 20

Typical hot spring in the Pumpernickel Valley project area..................................21

Resistivity map 50 to $75 \mathrm{~m}$ below surface contour .................................23

Distribution of the geothermal gradient wells..................................... 25

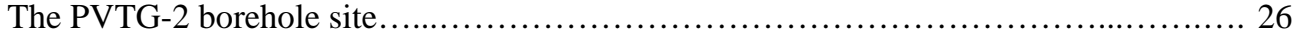

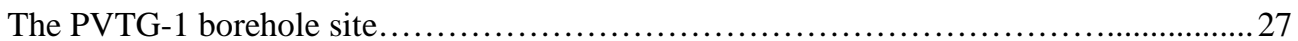

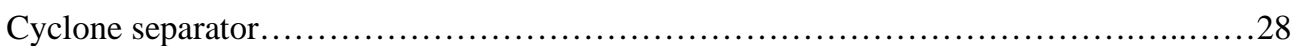

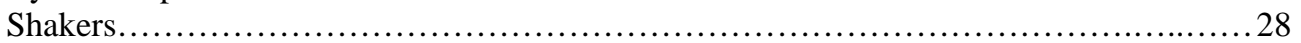

Typical Hobo thermistor setup............................................... 30

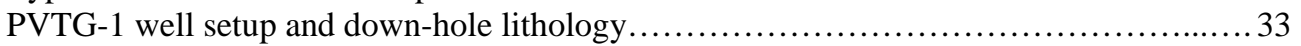

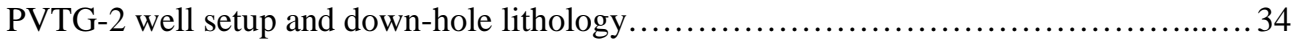

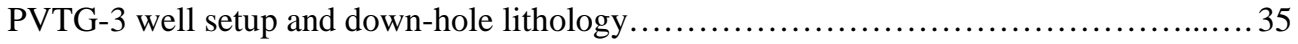

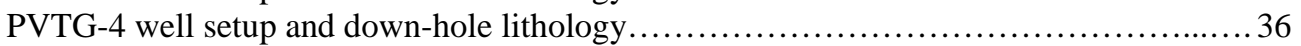

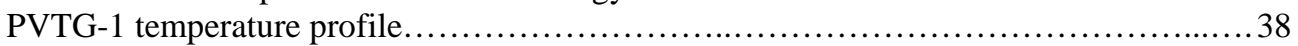

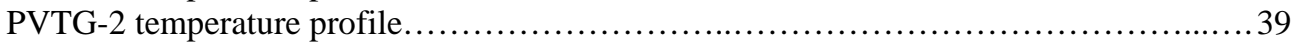

PVTG-3 temperature profile.................................................. 40

PVTG-4 temperature profile.................................................. 41

Pumpernickel Valley geothermal system - geothermal gradient map..................... 42

Temperature cross sections................................................ 43

Location of water samples.................................................. 45

Dixie Valley well locations, mapped faults, and basin depth.................................... 48 


\section{TABLES}

1 Geochemical Geothermometers (calculated by Tom Powell of Thermochem Inc.)......... 44

\section{LIST OF APPENDICES}

A: $\quad$ Statement of Qualifications

B: $\quad$ Chip logs

C: $\quad$ Geochemical data for water samples collected within and near the project area 


\section{SUMMARY}

The Pumpernickel Valley geothermal project area is located near the eastern edge of the Sonoma Range and is positioned within the structurally complex Winnemucca fold and thrust belt of north-central Nevada. A series of approximately north-northeast-striking faults related to the Basin and Range tectonics are superimposed on the earlier structures within the project area, and are responsible for the final overall geometry and distribution of the pre-existing structural features on the property. Two of these faults, the Pumpernickel Valley fault and Edna Mountain fault, are range-bounding and display numerous characteristics typical of strike-slip fault systems. These characteristics, when combined with geophysical data from Shore (2005), indicate the presence of a pull-apart basin, formed within the releasing bend of the Pumpernickel Valley - Edna Mountain fault system.

A substantial body of evidence exists, in the form of available geothermal, geological and geophysical information, to suggest that the property and the pull-apart basin host a structurally controlled, extensive geothermal field. The most evident manifestations of the geothermal activity in the valley are two areas with hot springs, seepages, and wet ground/vegetation anomalies near the Pumpernickel Valley fault, which indicate that the fault focuses the fluid up-flow.

There has not been any geothermal production from the Pumpernickel Valley area, but it was the focus of a limited exploration effort by Magma Power Company. In 1974, the company drilled one exploration/temperature gradient borehole east of the Pumpernickel Valley fault and recorded a thermal gradient of $160^{\circ} \mathrm{C} / \mathrm{km}$. The 1982 temperature data from five unrelated mineral exploration holes to the north of the Magma well indicated geothermal gradients in a range from 66 to $249^{\circ} \mathrm{C} / \mathrm{km}$ for wells west of the fault, and $\sim 283^{\circ} \mathrm{C} / \mathrm{km}$ in a well next to the fault.

In 2005, Nevada Geothermal Power Company drilled four geothermal gradient wells, PVTG-1, $-2,-3$, and -4 , and all four encountered geothermal fluids. The holes provided valuable water geochemistry, supporting the geothermometry results obtained from the hot springs and Magma well. The temperature data gathered from all the wells clearly indicates the presence of a major plume of thermal water centered on the Pumpernickel Valley fault, and suggests that the main plume is controlled, at least in part, by flow from this fault system.

The temperature data also defines the geothermal resource with gradients $>100^{\circ} \mathrm{C} / \mathrm{km}$, which covers an area a minimum of $8 \mathrm{~km}^{2}$. Structural blocks, down dropped with respect to the Pumpernickel Valley fault, may define an immediate reservoir. The geothermal system almost certainly continues beyond the recently drilled holes and might be open to the east and south, whereas the heat source responsible for the temperatures associated 
with this plume has not been intersected and must be at a depth greater than 920 meters (depth of the deepest well - Magma well).

The geological and structural setting and other characteristics of the Pumpernickel Valley geothermal project area are markedly similar to the portions of the nearby Dixie Valley geothermal field. These similarities include, among others, the numerous, unexposed en echelon faults and large-scale pull-apart structure, which in Dixie Valley may host part of the geothermal field.

The Pumpernickel Valley project area, for the majority of which Nevada Geothermal Power Company has geothermal rights, represents a geothermal site with a potential for the discovery of a relatively high temperature reservoir suitable for electric power production. Among locations not previously identified as having high geothermal potential, Pumpernickel Valley has been ranked as one of four sites with the highest potential for electrical power production in Nevada (Shevenell and Garside, 2003).

Richards and Blackwell (2002) estimated the total heat loss and the preliminary production capacity for the entire Pumpernickel Valley geothermal system to be at 35MW. A more conservative estimate, for the hot spring area only, was presented by GeothermEx Inc. (2004), which projected that power generation capacities for the Pumpernickel Valley site are 10 MW-30yrs minimum (probablility of $>90 \%$ ), and most likely 13 MW-30yrs. 


\section{PUMPERNICKEL VALLEY GEOTHERMAL PROJECT: THERMAL GRADIENT WELLS}

\section{Introduction}

This report documents the drilling operations and presents the technical results and information obtained from the thermal gradient wells in the Pumpernickel Valley geothermal project area near Winnemucca, in north-central Nevada. The report incorporates detailed geologic logs, temperature gradients, well construction, and the analyses of the fluid samples collected from the wells. This data is presented in a context of geological and geophysical information obtained prior to and during the drilling program.

The drilling has been a part of an ongoing geological and geophysical program that evaluates in detail the geothermal potential of the Pumpernickel Valley area. The area is located within the well-known Battle Mountain heat flow high and the NE-SW trending geothermal/structural belt, the Humboldt structural zone, which hosts numerous major geothermal fields, including Brady’s Hot Springs, Steamboat, Soda Lake, Dixie Valley, and Beowawe (e.g. Blewitt et al., 2003; Faulds et al., 2003).

The geothermal activity within the project area is manifested predominantly by two areas of active hot springs and a wider spread geothermal/hydrothermal alteration halo confined mainly to the hanging wall of the Pumpernickel Valley fault. There has not been any geothermal production from the Pumpernickel Valley property. However, a substantial body of evidence exists, in the form of available geothermal, geological and geophysical information, to suggest that the property hosts a structurally controlled, extensive geothermal field.

Nevada Geothermal Power Inc. and Inovision Solutions Inc., in cooperation with and with funding from the US DOE (GRED III - Phase I, Award DE-FG36-04GO 12340), drilled four thermal gradient wells on private land within the property. PTVG-1 was drilled to $305 \mathrm{~m}$ and approached temperatures of $46.4^{\circ} \mathrm{C}$; PVTG-2 was drilled also to $\sim 305 \mathrm{~m}$ and reached temperatures of $34.4^{\circ} \mathrm{C}$; PVTG-3 was drilled to $\sim 488 \mathrm{~m}$ with a temperature high of $80.8^{\circ} \mathrm{C}$; and PVTG-J was drilled to $\sim 360 \mathrm{~m}$ and intersected temperatures of $45.5^{\circ} \mathrm{C}$.

The geothermal gradient well drilling program was designed to map the near surface thermal anomaly implied by previous work and recent geophysical surveys. Following the completion of drilling, down-hole temperature readings were taken in all four wells that revealed anomalous gradients and indicated a considerable extent to the resource. 


\section{Location, access, physiography and climate}

The Pumpernickel Valley geothermal project is located in Pumpernickel Valley, 30 kilometers east of Winnemucca, in the Basin and Range geomorphic province of northern Nevada (Figure 1). The project is set in the southern portion of Pumpernickel Valley and on eastern slopes of the Sonoma Range, in the southeastern corner of Humboldt County, north-central Nevada. This portion of the valley trends approximately N-S and is flanked by the eastern Sonoma Range to the west, Buffalo Mountain to the east, and by the southern portion of Edna Mountain to the north. To the south, in Pershing County, Pumpernickel Valley is closed by the Tobin Range (Figure 2).

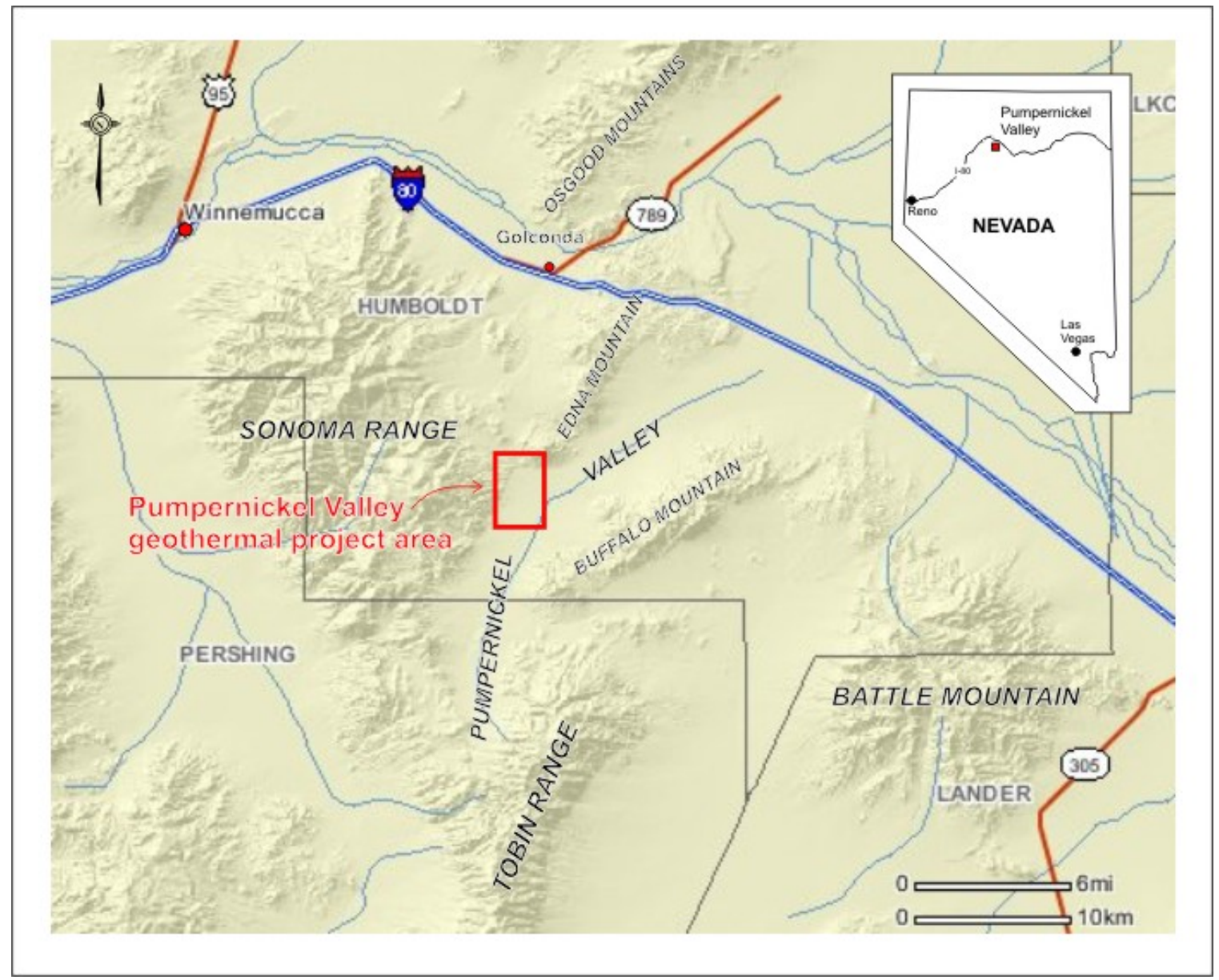

Figure 1. Location of the Pumpernickel Valley geothermal project area in north-central Nevada.

The project area is centered at $40^{\circ} 46^{\prime} \mathrm{N}$ Lat and $117^{\circ} 28^{\prime} \mathrm{W}$ Long on the west margin of Pumpernickel Valley. The project area surrounds a cluster of hot springs that occur at 1464-1481 meters elevation above sea level, on the west side of the valley and comprises five sections of private geothermal leases from Newmont USA Limited and four sections of federal lands from the BLM (lease pending), all arranged in a checkerboard manner. 
The infilling land belongs to ORMAT and the Tipton Ranch. The configuration of sections included in the project area is provided in Figure 3.

The Pumpernickel geothermal project area is accessible year round traveling from Winnemucca via Interstate Highway I-80, 24 kilometers east to Golconda.

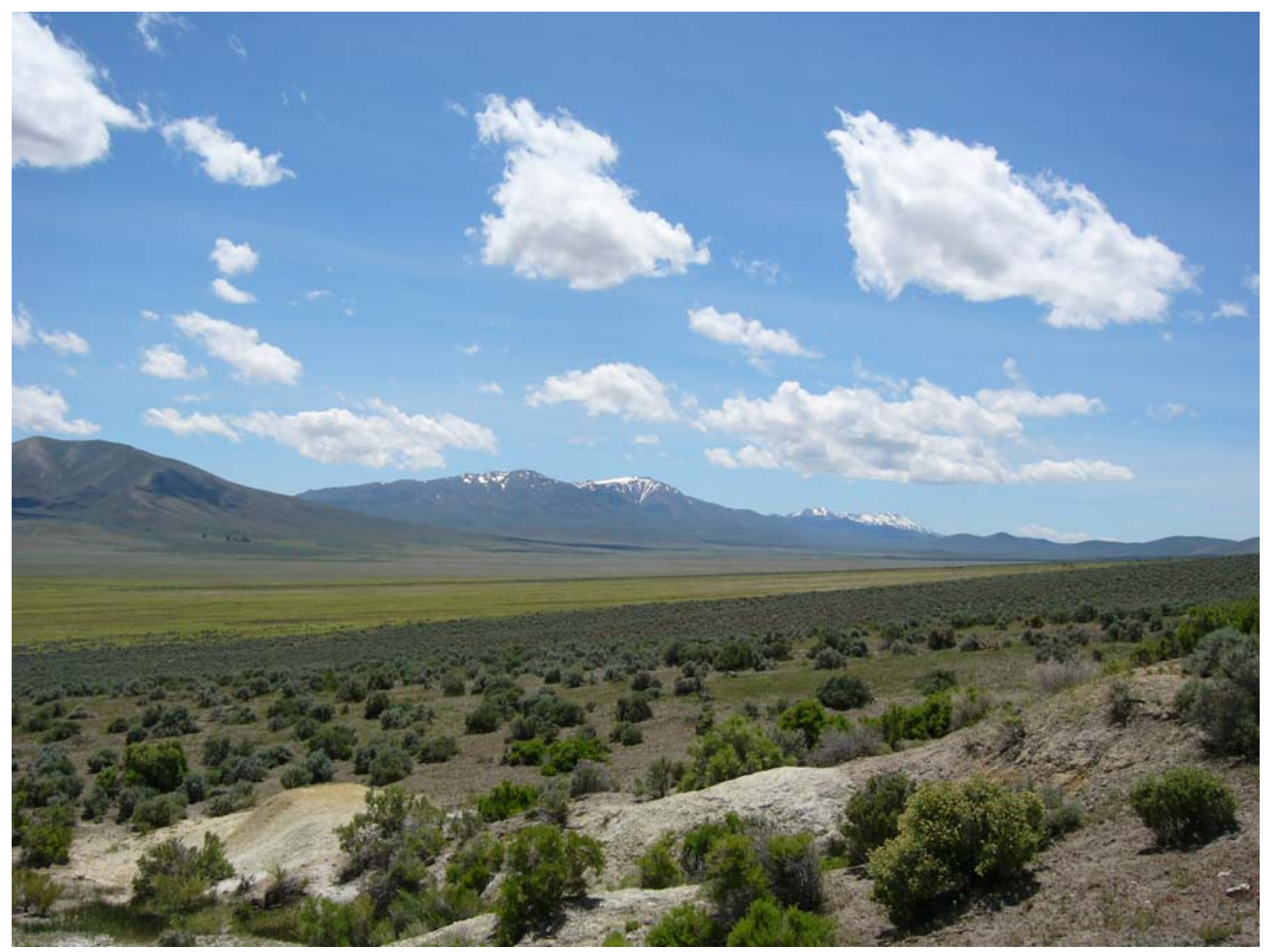

Figure 2. Pumpernickel Valley looking south from the hot springs area towards the Tobin Range. In the foreground alteration associated with the geothermal activity. Note vegetation dominated by sagebrush and desert grasses.

From Golconda 19 kilometers due south, a well-maintained county gravel road leads into Pumpernickel Valley and the project area. Variable and unimproved loose surface tracks provide further access to the western portion of the property.

Within the project area, the land surface is flat to gently sloping into Pumpernickel Valley with elevations ranging from $1,390 \mathrm{~m}$ to $1480 \mathrm{~m}$ above sea level. In the western portion, the Sonoma Range is moderately sloping up to approx. $1800 \mathrm{~m}$, and characterized by mainly moderate relief, although locally, in the westernmost portion the topography, it is steep. Vegetation consists of typical desert plants dominated by sagebrush, other shrubs, and desert grasses (Figure 2), with areas of desert hardpan without vegetation providing rangeland for cattle and goats. 


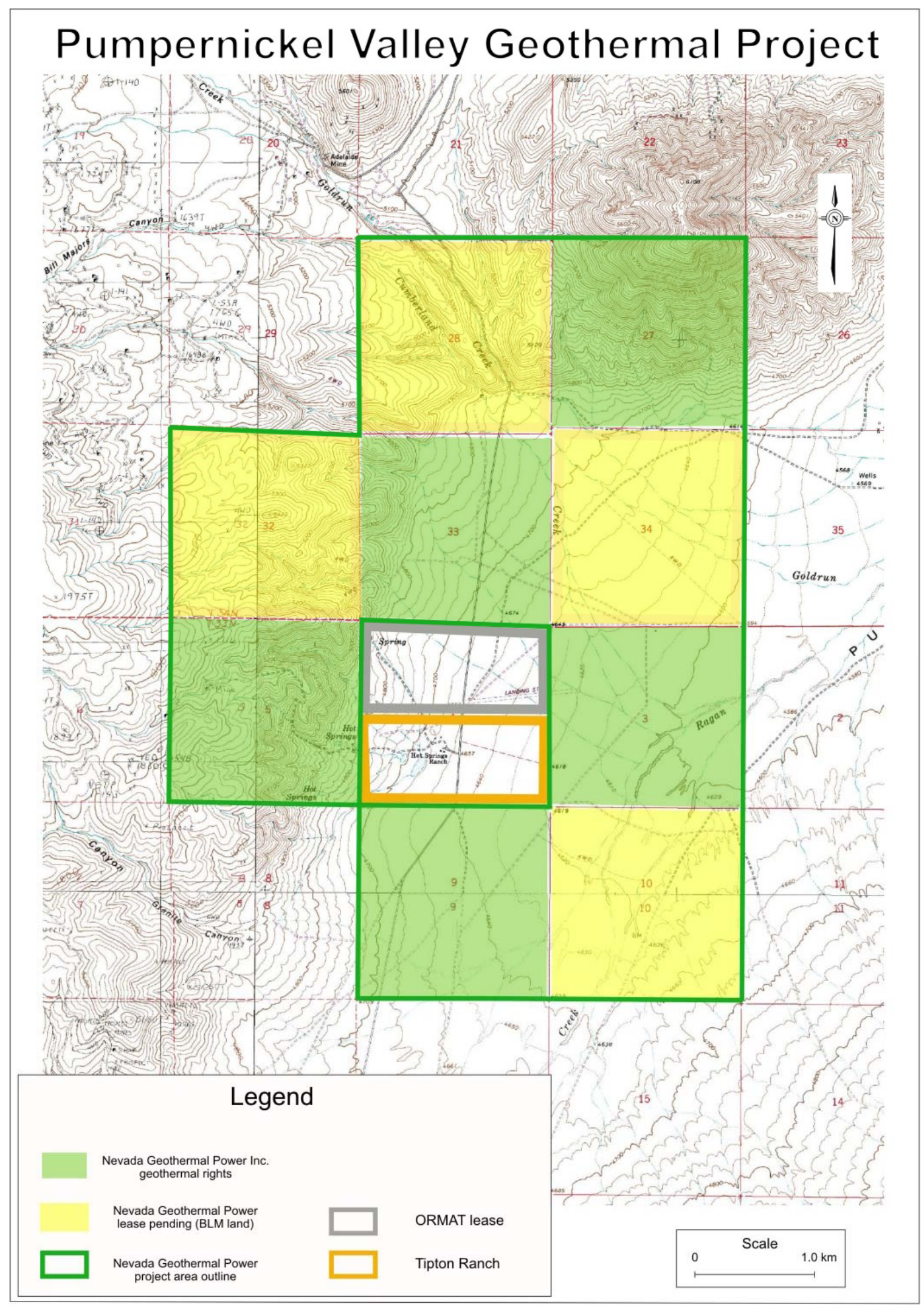

Figure 3. The Pumpernickel Valley project area and outlining geothermal rights. 
Pumpernickel Valley forms part of the Humboldt River hydrographic basin and the drainage from the valley is provided by the dry Ragan Creek to the river. The climate is arid to semi-arid. This valley is located in the high desert region and precipitation average $15 \mathrm{~cm}$ per annum with the majority of it coming from snow, occasional heavy spring rains, and sporadic summer thunderstorms. The summers are hot and winters generally mild with common overnight freezing conditions. The mean annual temperature is $10.6^{\circ} \mathrm{C}$ with highs of $40^{\circ} \mathrm{C}$.

\section{Power transmission facilities}

Several power transmission lines traverse the region and are managed by Sierra Pacific Power Company. A double $345 \mathrm{kV}$, northeasterly trending power transmission line crosses over the southernmost section of the valley. In addition, a $120 \mathrm{kV}$ transmission line crosses the region, with the Kramer Hill Substation located just south of Golconda.

\section{Previous work}

The Pumpernickel Valley area has had a prolific gold mining and mineral exploration history and has been actively explored as evidenced by numerous shafts, pits, trenches, adits, as well as at least three abandoned mines located west and northwest of the valley.

Geothermal exploration in the Pumpernickel Valley was initiated by Magma Power Co. at the Tipton Ranch (Hot Springs) in 1974. The reported temperatures of hot springs at Tipton Ranch were as high as $85^{\circ} \mathrm{C}$, whereas the "best" estimates of the thermal-aquifer temperature were $194-196^{\circ} \mathrm{C}$ (Mariner and others, 1974; in Garside and Schilling, 1979). Magma drilled a single geothermal well to a total depth of $919.6 \mathrm{~m}$ (3,071 ft - Garside and Schilling, 1979; updated 2003 by Shevenell and Garside, and references therein). The recorded bottom-hole temperature was $135^{\circ} \mathrm{C}$, with the last $91 \mathrm{~m}$ having a geothermal gradient of $160^{\circ} \mathrm{C} / \mathrm{km}\left(6.5^{\circ} \mathrm{F} / 100 \mathrm{ft}\right.$; S. Matlick, personal comm. in Shevenell and Garside, 2003).

In 1981-1982, the University of Nevada System (UNS), under contract to the U.S. Department of Energy (DE-AC08-NV10220), completed a regional assessment of the Pumpernickel Valley area (Trexler et al., 1982; Flynn and Trexler, 1982). The UNS fieldwork included geologic reconnaissance, geochemical sampling, satellite imagery, air photo interpretation, 2-meter depth temperature probe survey, gravity survey, seismic survey, soil mercury survey, and temperature gradient drilling.

The UNS work demonstrated that widespread geothermal fluids are likely channeled to the surface by range bounding faults. Temperatures of geothermal fluids were estimated to be $170^{\circ} \mathrm{C}$, based on chemical geothermometers. Mercury anomalies were recorded in soil north from the hot springs along the range front fault.

At this same time, the UNS crew gathered temperature data from seven pre-existing uncased mineral exploration holes found within the present project area. A thermistor 
probe and digital thermometer were used to record temperature versus depth. Two of these holes positioned near a fossil spring north of the Tipton Ranch had temperatures as high as $43^{\circ} \mathrm{C}$ at depth of $6 \mathrm{~m}$, and $44.6^{\circ} \mathrm{C}$ at depth of $4.6 \mathrm{~m}$. Temperatures in other wells located mainly west of the range-bounding fault were lower. The data from five of the holes (Appendix B) were used subsequently to calculate geothermal gradients in a range of 66 to $249^{\circ} \mathrm{C} / \mathrm{km}$ for wells west of the fault, and $283^{\circ} \mathrm{C} / \mathrm{km}$ for a well near the fault (Sadlier-Brown, 2004; revised by this author).

In, 1988, audio-magnetotelluric soundings; telluric and gamma-ray measurement; soilgas $\left(\mathrm{CO}_{2}, \mathrm{O}_{2}\right.$, and hydrocarbons) determinations; soil, pebble-coating, and sagebrush geochemical data were collected along two traverses across the Pumpernickel Fault, with the closest one just $300 \mathrm{~m}$ north from the Magma well and hot springs (Erdman et al., 1991). The geophysical and geochemical results from this survey indicated the presence of a buried, possibly mineralized fault east of and parallel to the Pumpernickel fault (op cit).

More recently collected magnetotelluric data and a 2-D resistivity model along a profile in the Pumpernickel Valley that included the project area indicated a $\sim 0.4 \mathrm{~km}$ thick basin fill underlain by resistive rocks characteristic of the lower Paleozoic units (Rodriguez and Williams, 2002).

In 2002, Shevenell and Garside revisited the Tipton Ranch hot springs as part of the Nevada Bureau of Mines and Geology program focused on evaluation of geothermal resources for electrical power generation and direct-use applications. The Na-K-Ca geothermometers based on new geochemical samples indicated the thermal-aquifer temperature at 175 to $192^{\circ} \mathrm{C}$, whereas a more conservative estimate based on the chalcedony geothermometer suggested a geothermal resource with a temperature of $125^{\circ} \mathrm{C}$ (Shevenell and Garside, 2003).

In February 2004, Nevada Geothermal Power Inc. acquired geothermal leases to five private sections of geothermal rights in a checkerboard pattern owned by the Newmont USA Limited and subsequently applied for four sections of BLM land (Figure 2). A preliminary geothermal evaluation was completed using the existing data augmented by new mapping and air photo analyses (Sadlier-Brown, 2004). In 2005, Inovision Solutions Inc. acquired an option to earn a 50\% joint venture interest in the project.

\section{Tectonic setting of the north-central Nevada}

The Pumpernickel Valley geothermal project is located within an extensive zone of recent deformation named the Humboldt structural zone (HSZ) (Faulds et al., 2004). The HSZ (Figure 4) includes mainly east-northeast-striking faults shown to accommodate sinistral and/or normal slip; it is thought to be related to west-northwest-oriented extension within the Basin and Range province. 
The HSZ roughly parallels a broad heat-flow anomaly, the Battle Mountain heat-flow high, which also covers much of northern Nevada and forms an east-northeast-trending zone extending from about Reno to Carlin. The HSZ trend correlates well with geothermal activity; productive moderate- and high-temperature, fluid-dominated geothermal systems such as Steamboat, Desert Peak, Brady's Hot Springs, Soda Lake, Rye Patch, Dixie Valley, and Beowawe lie within this zone.

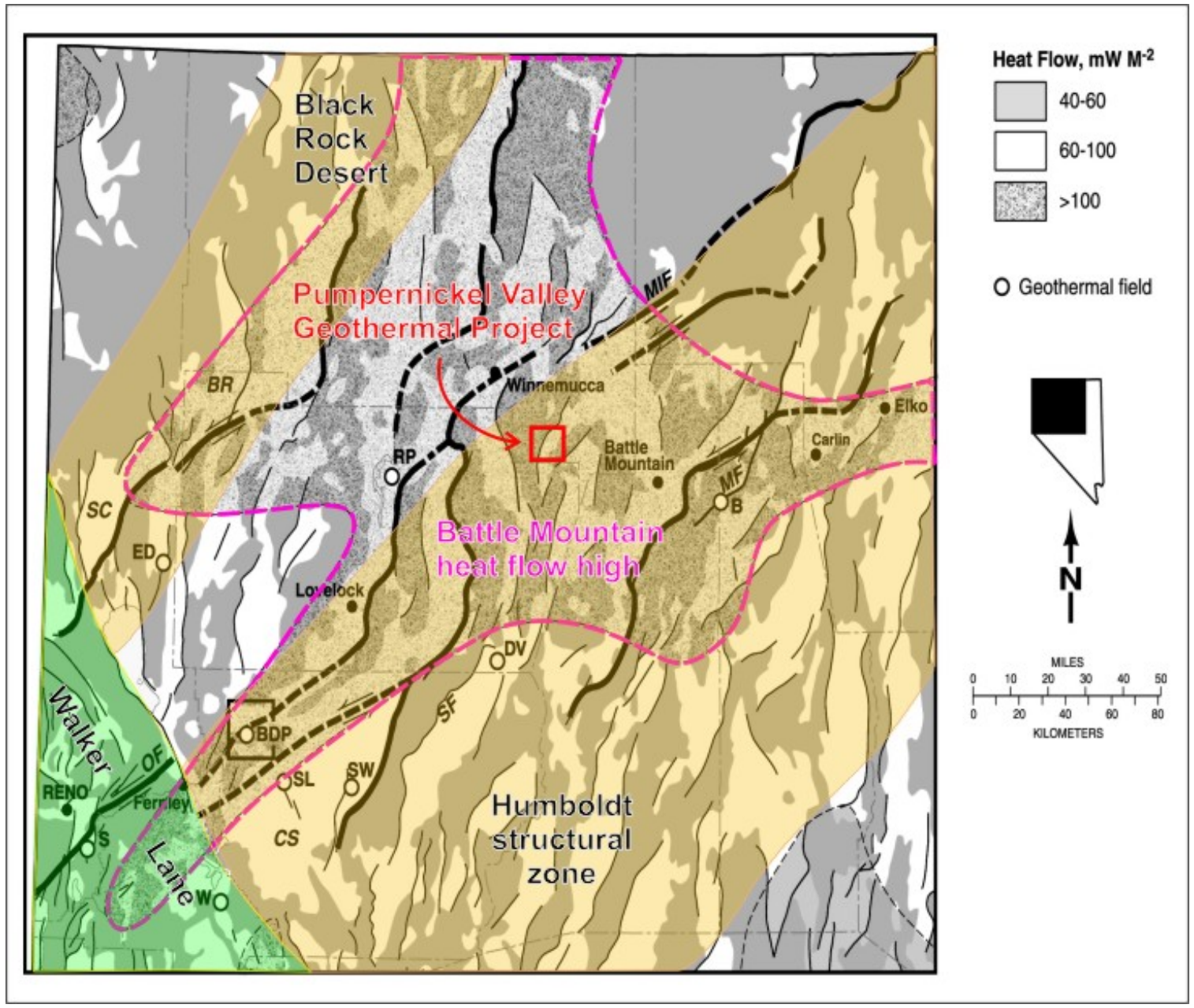

Figure 4. General map of the Battle Mountain heat flow high in northern Nevada (from Faulds et al., 2003) with the superimposed Humboldt structural zone, Black Rock Desert, and Walker Lane belts (modified after Faulds et al., 2004). Bold lines represent major northeast-striking faults. Abbreviations for the relevant geothermal fields are: BDP - Brady-Desert Peak; B - Beowawe; DV - Dixie Valley; S Steamboat; SL - Soda Lake; SW - Stillwater.

Tectonic extension and high heat flow in northwestern Nevada result most likely from the shallow depth of the Moho (e.g. Louie et al., 2003 and 2004; Lerch et al., 2004). A new crustal refraction profile which follows the HSZ indicated that the crust there is among the thinnest in the Basin and Range (Louie et al., 2003 and 2004). This refraction survey detected anomalously thin crust in the Battle Mountain area, immediately east of Pumpernickel Valley, with a Moho depth of 19-23 km over a region of approximately $150 \mathrm{~km}$ wide that is surrounded by more typical, 30-km-thick crust (Figure 5). 


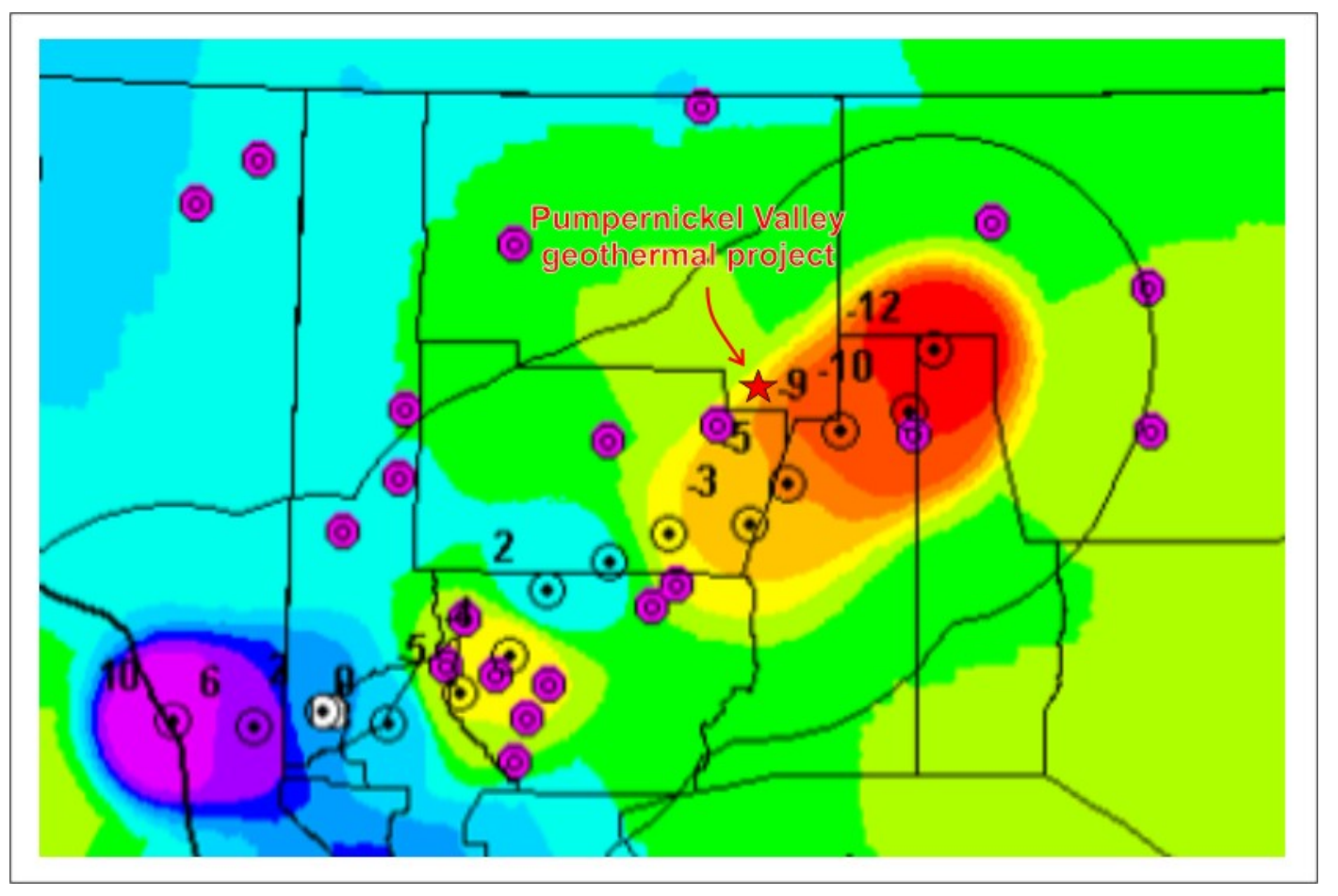

Figure 5. Crustal thicknesses for Nevada from Louie et al. (2004). Warmer colours represent thinner crust; purple circles - extensional-type geothermal systems; circles with dots - new seismic data (numbers refer to the difference between new and old data in $\mathrm{km}$ ).

\section{Geology of the Pumpernickel Valley area}

\section{Regional geology}

The Pumpernickel Valley area is located within the structurally complex Winnemucca fold and thrust belt of north-central Nevada that includes three different tectonostratigraphic units or allochthons (Figure 6). These units are regionally extensive, continue almost uninterrupted throughout numerous northeast-trending ranges, and are comprised of early Triassic Golconda, the Paleozoic Roberts Mountains, and the postTriassic Mesozoic Winnemucca allochthon (e.g. Stahl, 1989; Ludington et al., 1996; Ketner, 1998; McCollum and McCollum, 2004).

The structural development of these allochthons involves an early, easterly-directed movement of the Roberts rocks during the Antler Orogeny and subsequent eastward thrusting of the Golconda rocks during the Sonoma Orogeny on the top of the Roberts Mountains. After the Antler Orogeny, but before the emplacement of the Golconda allochthon, sedimentary and volcanic strata of Upper Paleozoic age (the overlap succession) were deposited unconformably on deformed rocks of the Roberts Mountains allochthon. 


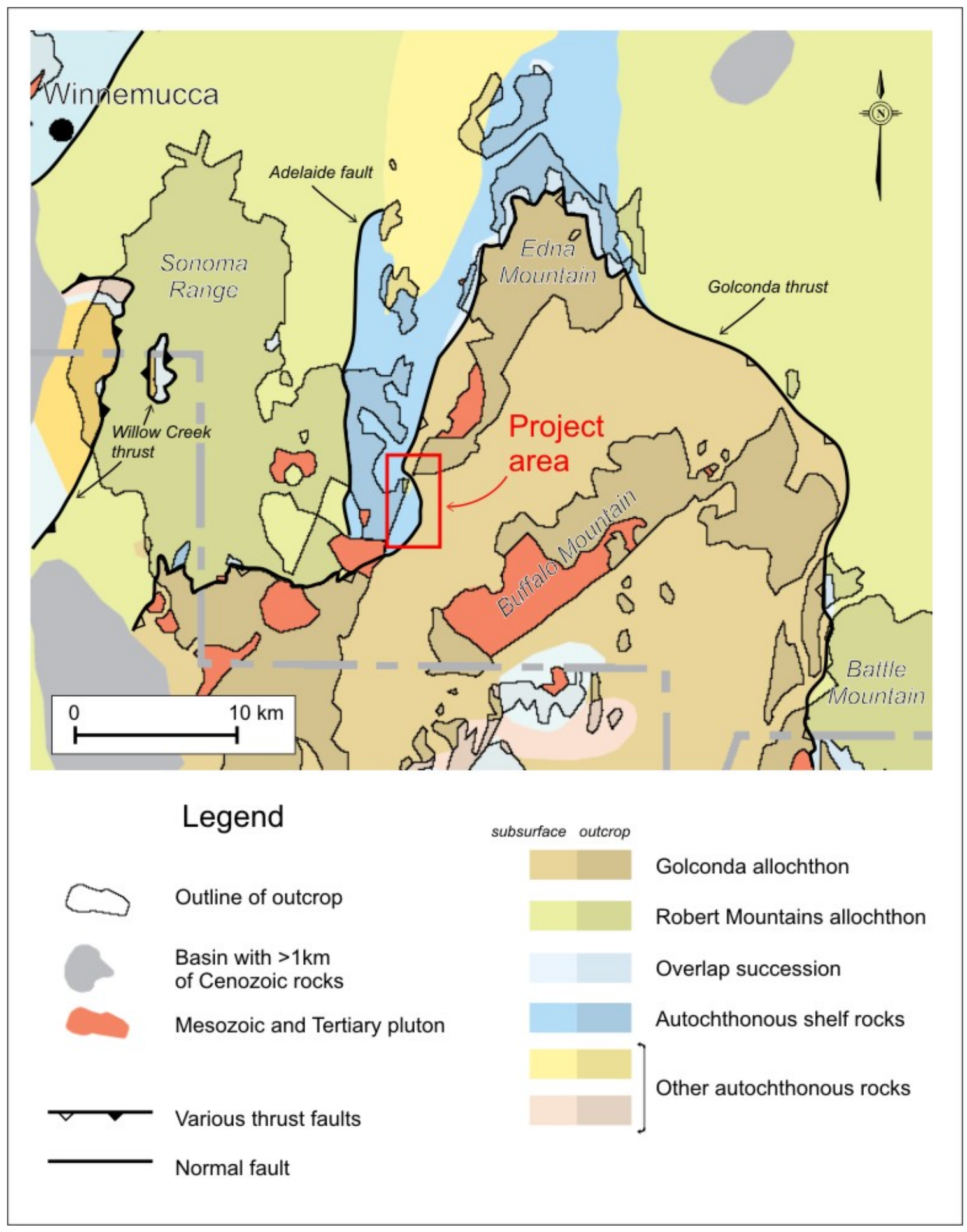

Figure 6. Regional tectonic setting of the project area modified from Ludington et al., 1996. 
The Roberts and Golconda rocks were thrust again, this time from east to west, during the Winnemucca Orogeny and incorporated into the Winnemucca allochthon. A postWinnemucca, Jurassic or Cretaceous orogenic event, characterized by N-S shortening affected the entire Winnemucca allochton.

All these allochtons are locally covered by Tertiary tuffs and other volcanic rocks, and cut by numerous high-angle faults related to the extensional Basin and Range tectonics.

\section{Geology of the project area}

The Pumpernickel Valley geothermal project area is underlain by Paleozoic strata included in three major units: the Preble Formation, the Pumpernickel Formation and Havallah Formation, and the Edna Mountain Formation (Figure 7).

Rocks in the western part of the valley and on the eastern slopes of the Sonoma Range are included in the Preble Formation (Silberling, 1975; Marsh and Erickson, 1978). The northern portion of the valley consists of rocks represented by the Havallah sequence of Upper Devonian to Permian age, comprised of dominantly siliceous sedimentary rocks. Rocks of the Edna formation outcrop in the eastern portion of the Sonoma Range, next to Pumpernickel Valley and the range-bounding fault.

Numerous lithostratigrapic repetitions in the area are attributed to tight and isoclinal folding, and the intra-formational imbrication associated with several events of thrusting. The recent overprint by high-angle normal faults related to the Basin and Range tectonism event adds further to the overall complexity.

\section{Preble Formation}

In the Pumpernickel Valley area, the Preble Formation consists mainly of strongly deformed sedimentary rocks that are weakly to strongly foliated, regionally metamorphosed to greenschist facies, and locally, near small intrusive bodies, are metamorphosed thermally. Within the project area, the Preble Formation is characterized by polyphase folding and imbricate thrusting (Szybinski, 2005), and the metasedimentary rocks occur in discontinuous, internally strained thrust panels surrounded by variably dipping brittle shear zones. This author concluded that the Preble Formation possibly represents a sequence of merely genetically linked, interleaved thrust slices (op cit).

The main body of the formation is comprised of predominantly olive-grey phyllite to quartz mica schist with some quartzite and limestone. A smaller area is underlain by grey to blue-grey, locally recrystallized dolomitic limestone with some phyllite and mudstone.

There are no fossils found locally in the Preble Formation; the Middle Cambrian to Lower Ordovician age of the unit, and the relationship, have been inferred by a correlation with similar dated rocks in the nearby Osgood Mountains (Hotz and Willden, 1964, in Silberling, 1975; Madden-McGuire and Marsh, 1991 and references therein; Boskie, 2001). 


\section{Pumpernickel Formation and Havallah Formation}

The northeastern corner of the property encompasses the southern tip of Edna Mountain, which is the type area of the Golconda thrust. The rock assemblage within the hanging wall of the Golconda thrust (chert, argillite, quartzite, minor limestone, with lesser greenstone of the Upper Carboniferous age) has been originally sub-divided into two litho-tectonic units, the Pumpernickel Formation and Havallah Formation (Marsh and Erickson, 1978).

Numerous subsidiary thrust faults and the associated west-to-northwest-striking folds imbricate and juxtapose the various units. For this reason, in the western Sonoma Range, Silberling (1975) and Stahl (1987) combined both units together as the Havallah sequence. Here, this nomenclature has been applied also to the Pumpernickel Valley area.

\section{Edna Mountain Formation}

The Edna Mountain Formation forms a part of the Antler "overlap" sequence, which is structurally overlain by the Golconda allochthon. The formation consists of a mainly brown, blocky weathering, fine- to medium grained, dark-grey calcareous quartzite, locally with black chert fragments; it grades into argillaceous, sandy siltstone. Brachiopod fauna of Late Permian age was found in these rocks along the banks of Goldrun Creek just northwest of the project area (Erickson and Marsh, 1978).

\section{Younger volcanic, intrusive, and sedimentary rocks}

Brownish-red, blocky weathering, coarsely porphyritic dykes of probable Upper Cretaceous age intrude rocks of the Preble Formation and follow some of the EWtrending ridges in the western portion of the property.

Intensely altered, grayish-green to cream-coloured quartz diorite dykes and sills intrude rocks of the Preble Formation in the south and central part. Several light-brown to cream in colour, altered quartz porphyry dykes and sills also intrude the Havallah sequence.

Tertiary volcanic rocks in the area include the Oligocene partly welded, rhyolite ashflow tuff, the Miocene vitrophyre or tuff (Figure 8), and Pliocene basaltic flows (Erickson and Marsh, 1978). A high level, poorly sorted, boulder-rich Tertiary gravel covers some ridges and valleys in the map area (Figure 9).

\section{Quaternary deposits}

Quaternary alluvium (clay, silt, sand and gravel) fills the Pumpernickel Valley and it is covered with the gravel fans and pediment veneer along the range-bounding faults (Figure 10). Using gravity data and a computer-generated gravity profile, Erickson and Marsh (1978) estimated the thickness of the gravel and alluvium in the western portion of the valley to be less than $100 \mathrm{~m}$. 


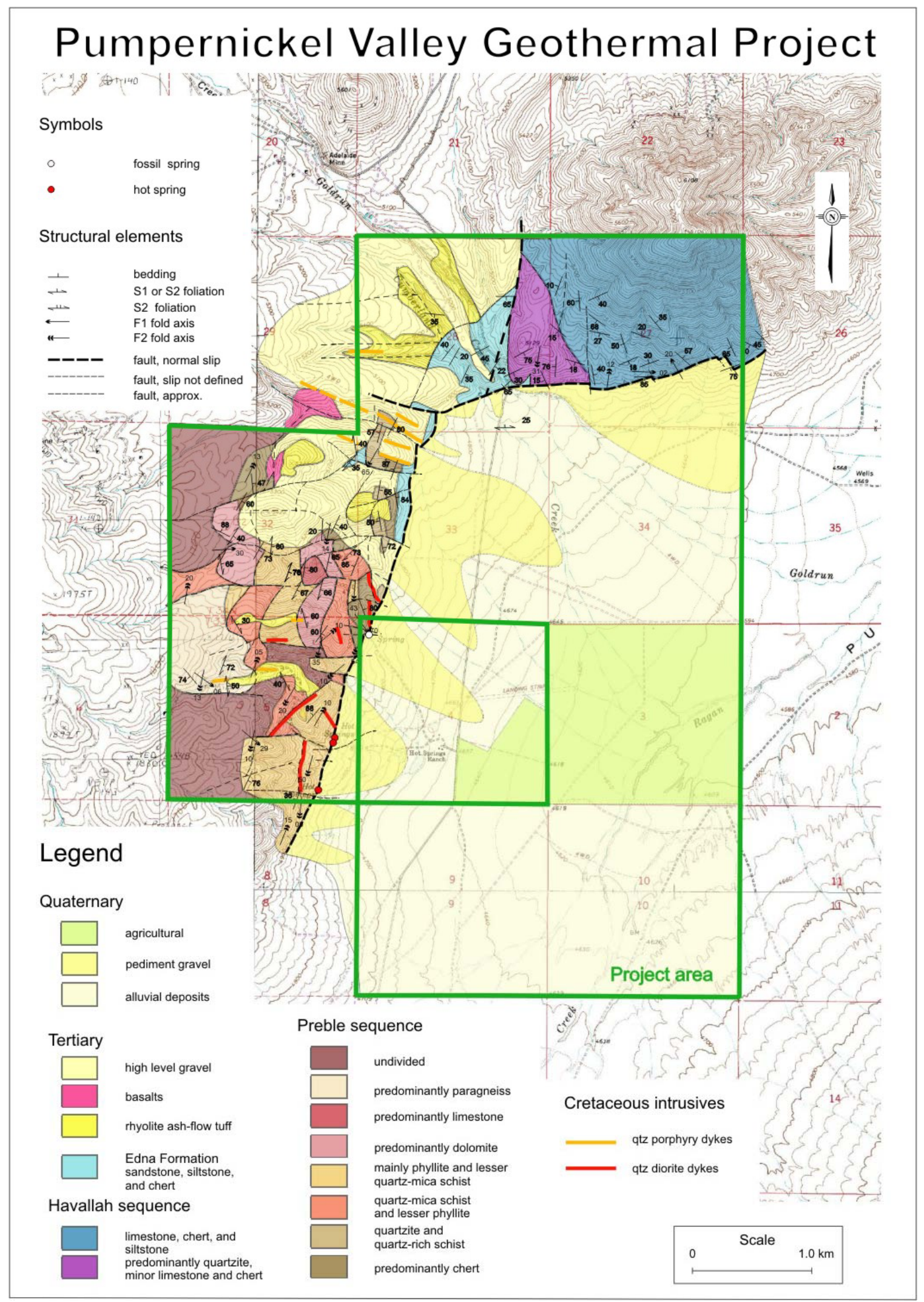

Figure 7. Preliminary geological map of the Pumpernickel Valley project area with additions from Marsh and Erickson (1978). 


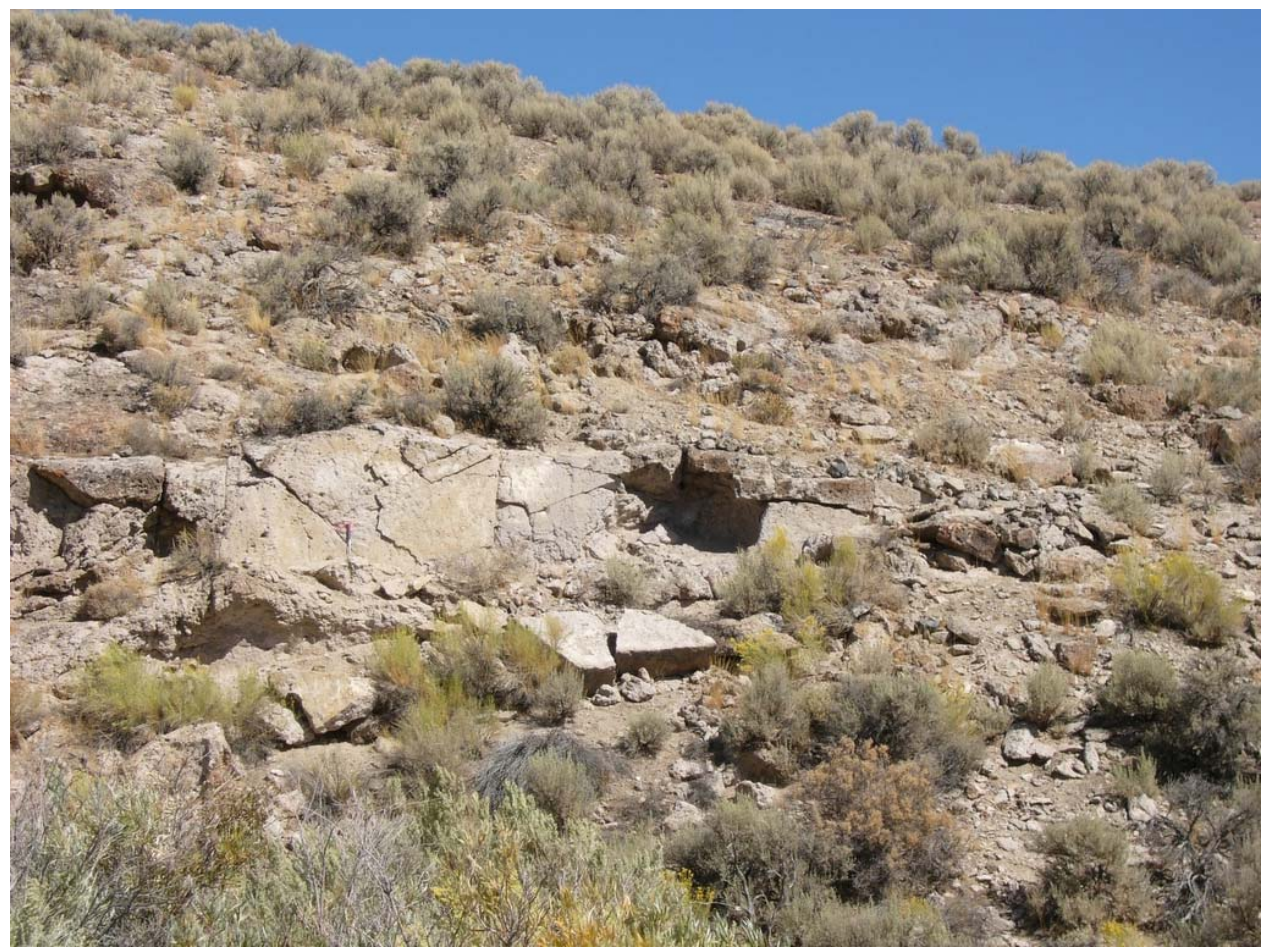

Figure 8. Outcrop of partly welded, somewhat blocky, Tertiary rhyolite ash-flow tuff on the eastern side of Cumberland Creek, section 28. A similar rock type has been drilled through in the thermal gradient hole PVTG-1.

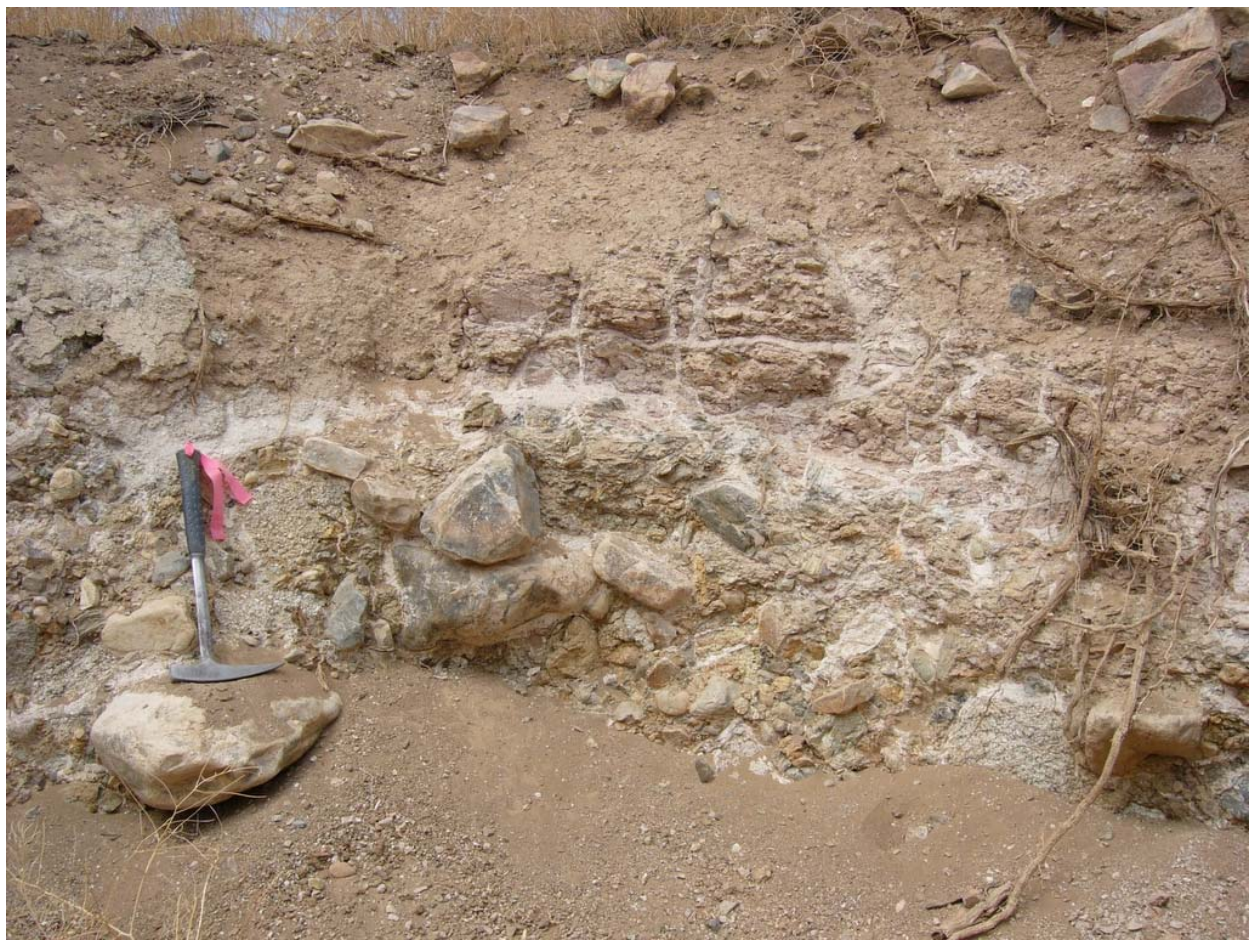

Figure 9. A typical, poorly sorted and partly consolidated, boulder-rich Tertiary gravel overlying rocks of the Preble Fm. It is exposed in a trench west of the Pumpernickel Valley fault, on the top of a hill in the section 32. A similar rock type forms lower portions of the thermal gradient holes PVTG-1and PVTG-3. 
The Magma well, located east of the hot springs on Tipton Ranch, reached basement rocks at a depth of 186 m (610 feet; Well Drillers Report \#14542, Division of Water Resources, State of Nevada, 1975). Approximately northeast of the Magma well, Santa Fe Pacific Mining drilled 213 meters of overburden and the audio-magnetotelluric traverses provided evidence of a buried fault at about 350m depth (Erdman et al., 1991). A recent 2-D resistivity model along the E-W profile within the Pumpernickel Valley project area indicated a relatively shallow, $\sim 0.4 \mathrm{~km}$, basin fill underlain by resistive rocks that are characteristic of the lower Paleozoic units (Rodriguez and Williams, 2002).

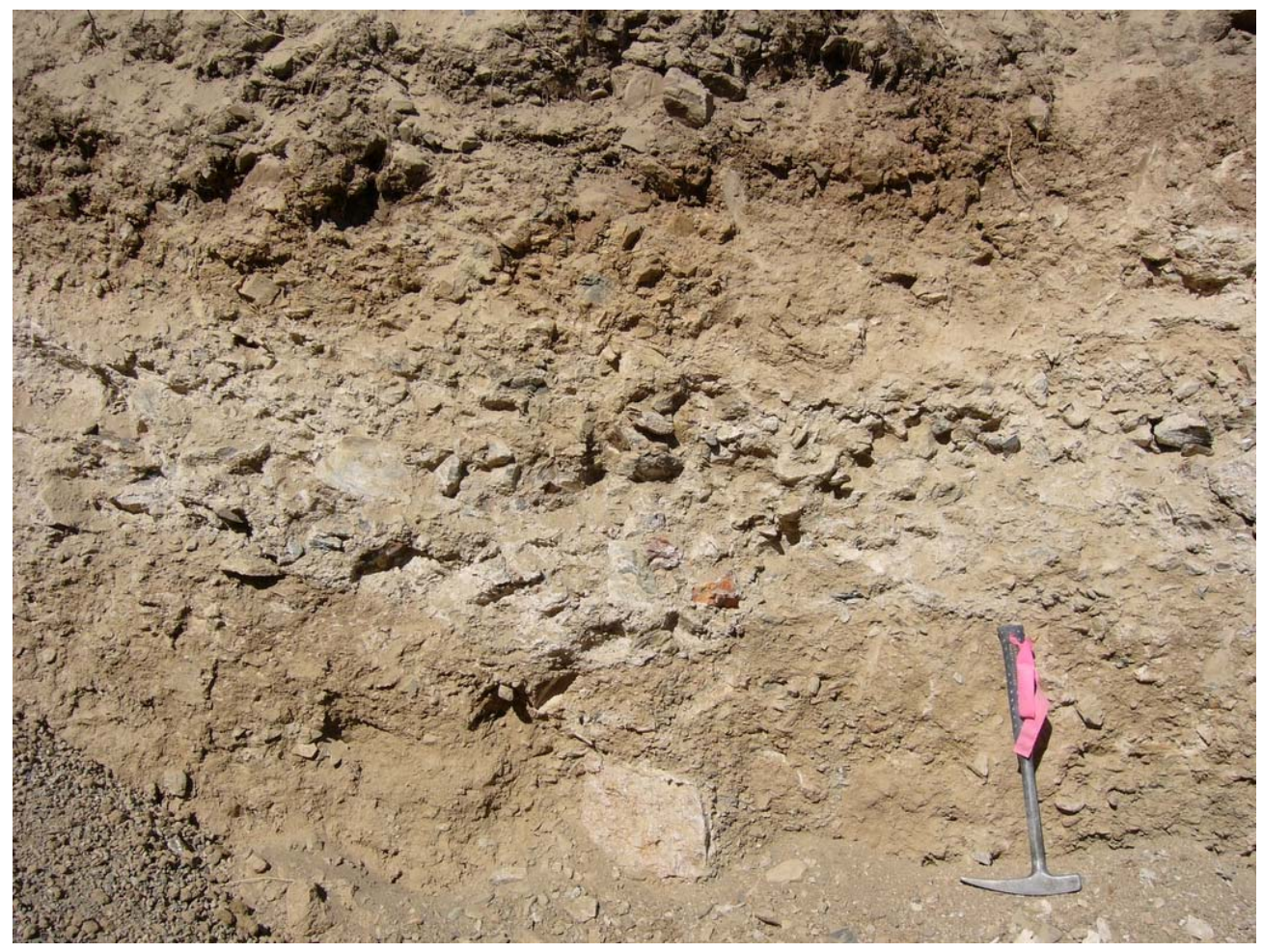

Figure 10. A poorly sorted, Quaternary gravel (a mix of a pediment gravel and alluvial deposit) on the floor of Pumpernickel Valley within the north-central portion of the project area. The section is exposed in the sump pit dug near the thermal gradient hole PVTG-3.

\section{Structure of the Pumpernickel Valley project area}

The Pumpernickel Valley area is located within a west verging, poly-deformed fold-andthrust belt, formed as a result of several regional deformation events. As a result, various lithological units occur repeated in a number of discrete, large polyphase fold panels bounded by thrust fault zones and are characterized locally by contrasting structural styles.

Folds, foliations, and minor kinematic features vary in style, orientation, as well as in abundance from panel to panel. There are at least two, and possibly up to four main fold 
generations, with younger, more open to tight folds refolding earlier tight and isoclinal folds.

Thrust faults are common, but difficult to recognize due to poor exposure and because thrusts are usually parallel or sub-parallel to the foliation fabric and/or to the locally preserved bedding. An extensive network of faults, shear zones, and fractures cut across the folded rocks and anastomoze around lenses of lower strain rocks. The majority of these faults and shear zones, and other structural elements are about parallel to or at an acute angle to the regional $\sim \mathrm{N}$ trend of lithological units in the Preble Formation.

Many of the fault-bounded blocks within the Preble Formation zone have been the focus of extensive alteration and clearly the bounding faults participated in channeling hydrothermal fluids. The alteration is mainly represented by limonitization and additional leaching and oxidization near the surface.

\section{Basin and Range tectonism}

There is a series of approximately north-northeast-striking faults in the eastern Sonoma Range and western Edna Mountain. The majority of these faults exhibit normal displacement, with locally some reverse faulting present, as well. These faults are superimposed on the earlier structures, divide the outcrop into numerous fault-bounded blocks, and are responsible for the final overall geometry and distribution of pre-existing structural features on the property (Figure 11).

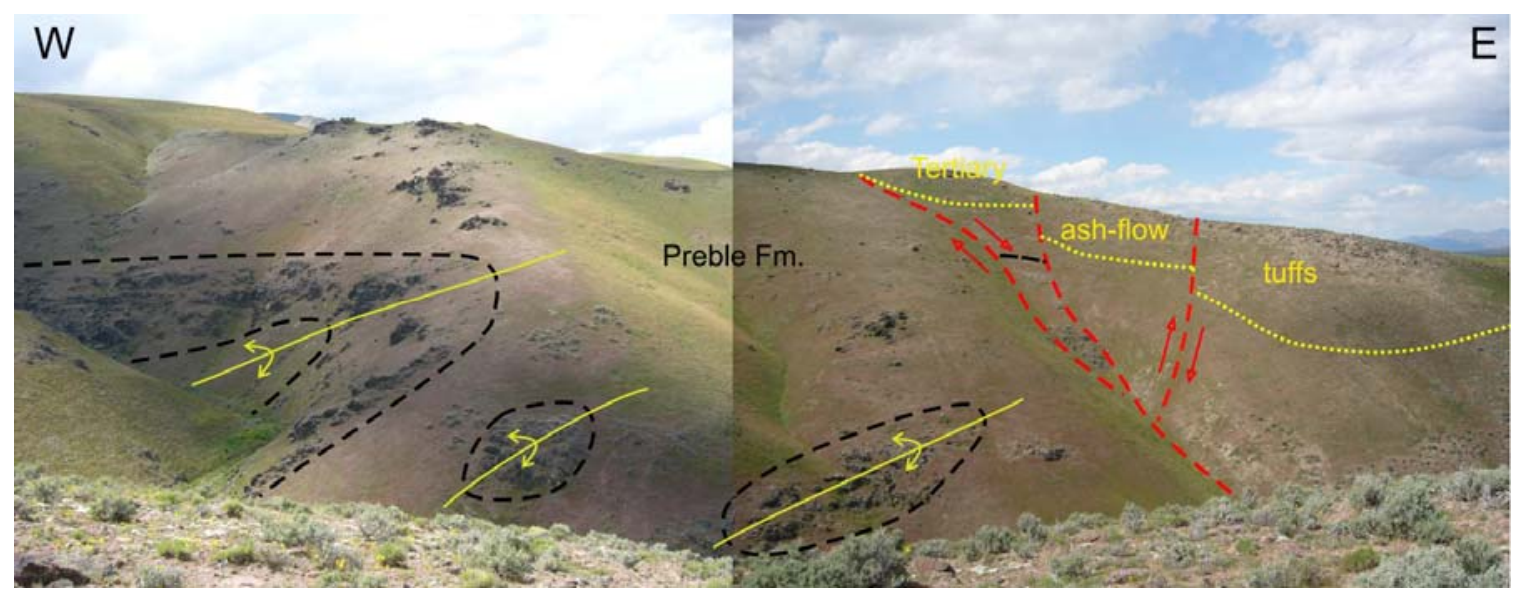

Figure 11. The $\sim \mathrm{E}-\mathrm{W}$ section of the Preble sequence and Tertiary ash-flow tuffs located west of the thermal gradient hole PVTG-2; looking north. The Preble rocks in the west and central part of the section are characterized by a series of the pre-Tertiary tight folds (antiforms outlined by the black dashed lines and axes marked by yellow symbols); red dashed lines indicate the Basin and Range faults (arrows show direction of movement); yellow dotted lines represent approximate contacts between the Preble sequence and the overlying Tertiary ash-flow tuffs.

It appears that the majority of the late brittle normal- and strike-slip deformation took place concurrently with the Basin and Range tectonics. Extension in the eastern portion of the Sonoma Range, near the range-bounding fault, has been relatively significant and is reflected by juxtaposition of the earlier structural elements and stratigraphic 
displacements of Tertiary volcanic rocks (Figure 11). In the western portion of the project area however, extensional faulting can essentially be regarded as a "noise", superimposed on the generally very well constrained dip-slip kinematic history of the thrust and fault belt.

\section{Major Faults}

There are two major faults in the project area, Pumpernickel Valley fault and Edna Mountain fault, and both are considered to represent one fault system by USGS (Anderson, 2000). Both faults are discontinuous, very steep (probably $>75^{\circ}$ ), vary in strike, as well as height and shape.

The Pumpernickel Valley fault is the prominent north-northeast trending structure and forms the structural break between the eastern Sonoma Range and western Edna Mountain, and between the Sonoma and southern Pumpernickel Valley basin. Further north, beyond the Edna Mountain fault, a probable extension of the Pumpernickel Valley fault juxtaposes Tertiary volcanic rocks against Paleozoic. The Pumpernickel Valley fault displays a very gradual geomorphic expression typical of an inactive fault front.

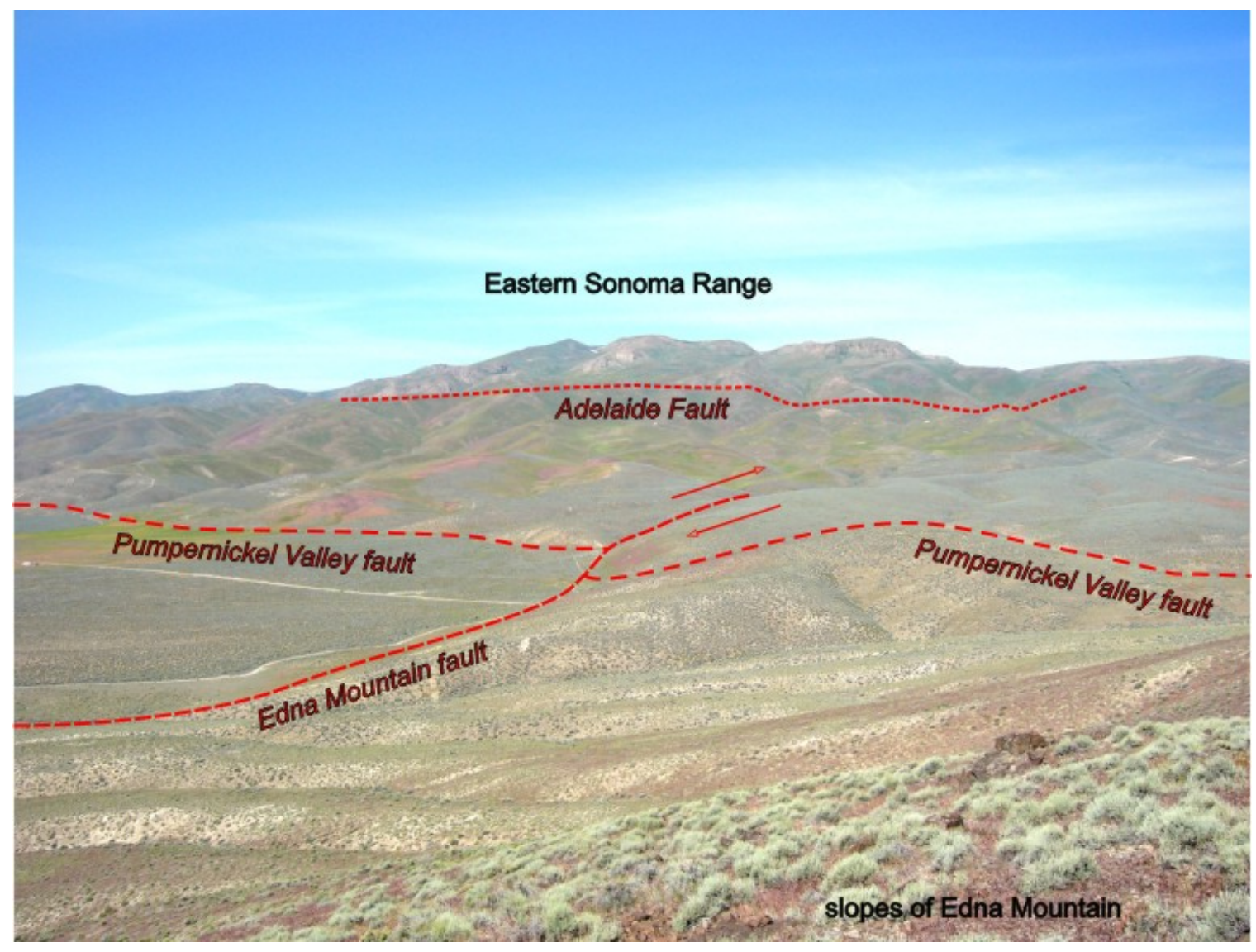

Figure 12. Panoramic view of the eastern Sonoma Range and Pumpernickel Valley area looking WSW from the slope of Edna Mountain; red dashed lines indicate faults referred to in the text; arrows show direction of movement. The Adelaide Fault juxtaposes rocks of the Preble sequence and the Roberts Mountains allochthon (see Figure 6). 
The Edna Mountain fault is a discontinuous, in general east-northeast- to northeasttrending structure, which defines the boundary between Edna Mountain and Pumpernickel Valley and juxtaposes bedrock against Quaternary alluvium. The eastnortheast-trending portion of the Edna Mountain fault shows a relatively sharp piedmontto-range break in slope, typical of the recently active major mountain fronts.

The exact sense of movement on either fault has not been established. The down-dip component of movement on both faults is clearly normal. The strike-slip component of the latest movement on the Edna Mountain fault has been dextral strike-slip, as indicated by the nearly vertical, quartz-filled gashes developed in quartzites along the fault trace.

\section{Pumpernickel Valley geothermal system}

In the Pumpernickel Valley, active and fossil thermal features were mapped using GPS and aerial photos. The mapped features included both hot and cold springs and seepages, wet soil spots and/or vegetation concentrations, accumulation of salt minerals and sinter/silcrete on the surface, and hydrothermal alteration (Figure 13 and 14). Sinter and silcrete (variably lithified sands, colluvium, roots, etc.) appear to be formed predominantly with calcium carbonate as the cementing agent.

The interpretation of some features was not simple, as the area has been extensively modified by trenching, digs, drilling, and various mining activity. This is the case particularly in the fossil spring area located north of the Tipton Ranch, and that area has not been mapped in detail.

At least two creeks flow from the west into the area occupied by the Pumpernickel Valley fault, and one flows from the northeast into the valley across the Edna Mountain fault; all provide a good seasonal source of water recharge for the geothermal system.

\section{Geothermal features}

The most obvious surface manifestation of the geothermal activity in the valley are two clusters of hot springs and wet ground with anomalous vegetation located immediately east of the Pumpernickel Valley fault and west of the Tipton Ranch. The larger of two clusters contains numerous active hot springs that follow a low lying, east-trending and elongate mound of calcareous tufa. The mound seems to be structurally controlled and bounded by a system of faults (Figure 14). Most of these springs display relatively low flow, but the combined discharge from the area has been estimated to be in excess of 400 L/min (Shevenell and Garside, 2003).

The Magma well, which is sited about 400 m east from the Pumpernickel Valley fault and this cluster of springs, spatters continuously at the surface throughout a fracture in the wellhead and the fluid deposits travertine all over the wellhead and surrounding area. The well is artesian with the estimated flow of $\sim 1136 \mathrm{~L} / \mathrm{min}$ and it marks the easternmost manifestation of the geothermal system (Well drillers report, Log No. 14542). 


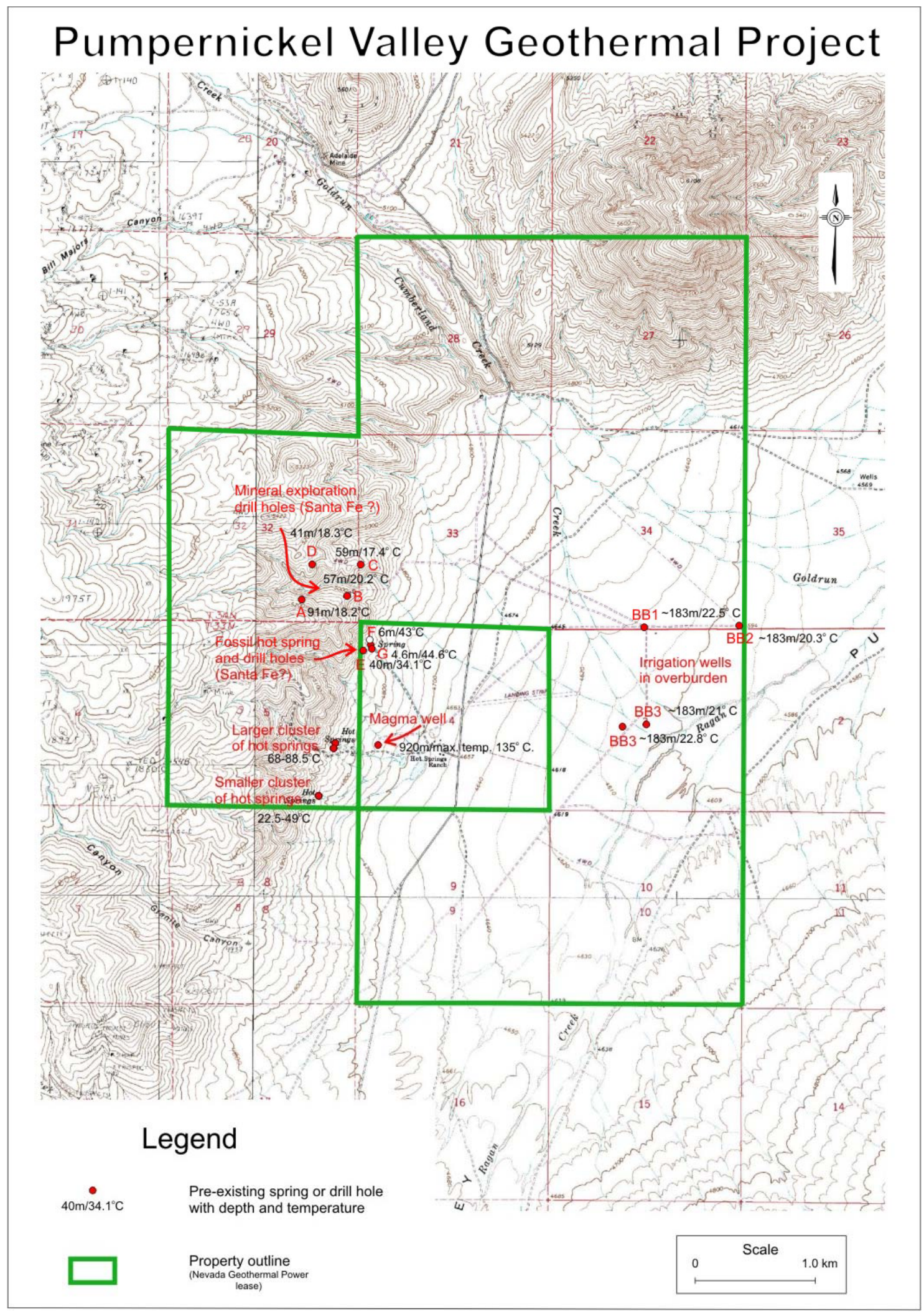

Figure 13. Distribution of the hot spring clusters, location of the Magma well, and other wells with geothermal fluids within the project area. Data from wells A-G are presented in Appendix B. 


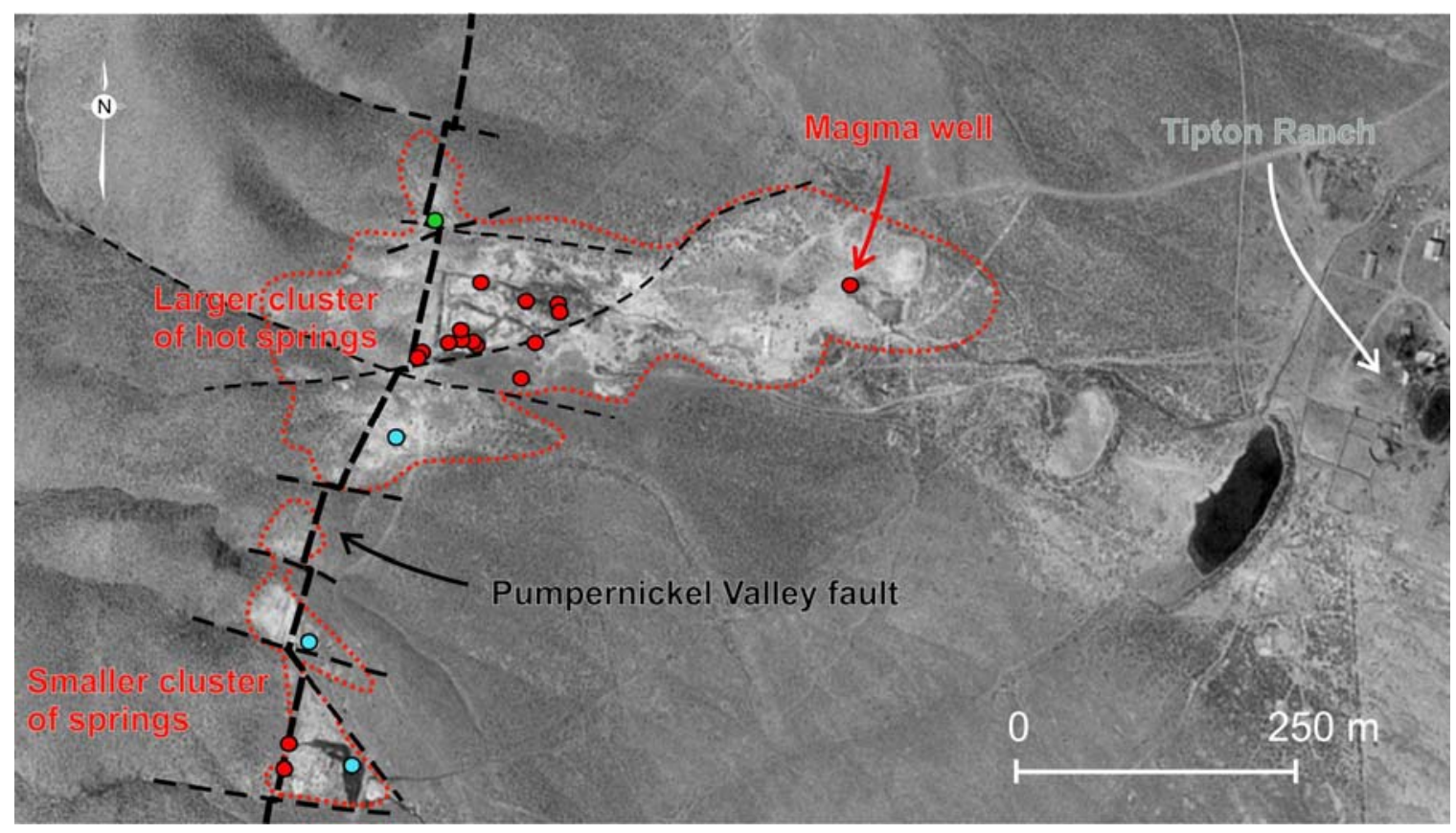

Figure 14. Map of the hot spring and Tipton Ranch area with geothermal features and faults; tufa mounds (sinter and silcrete) are delineated by dotted red lines; hot springs and seepages shown as red dots; cold spring and seepages with anomalous vegetation concentrations shown in blue, whereas the anomalous vegetation only in green. The approximate Pumpernickel Valley fault trace is drawn as a thicker dashed line, whereas probable cross-faults are sketched as thinner dashed lines.

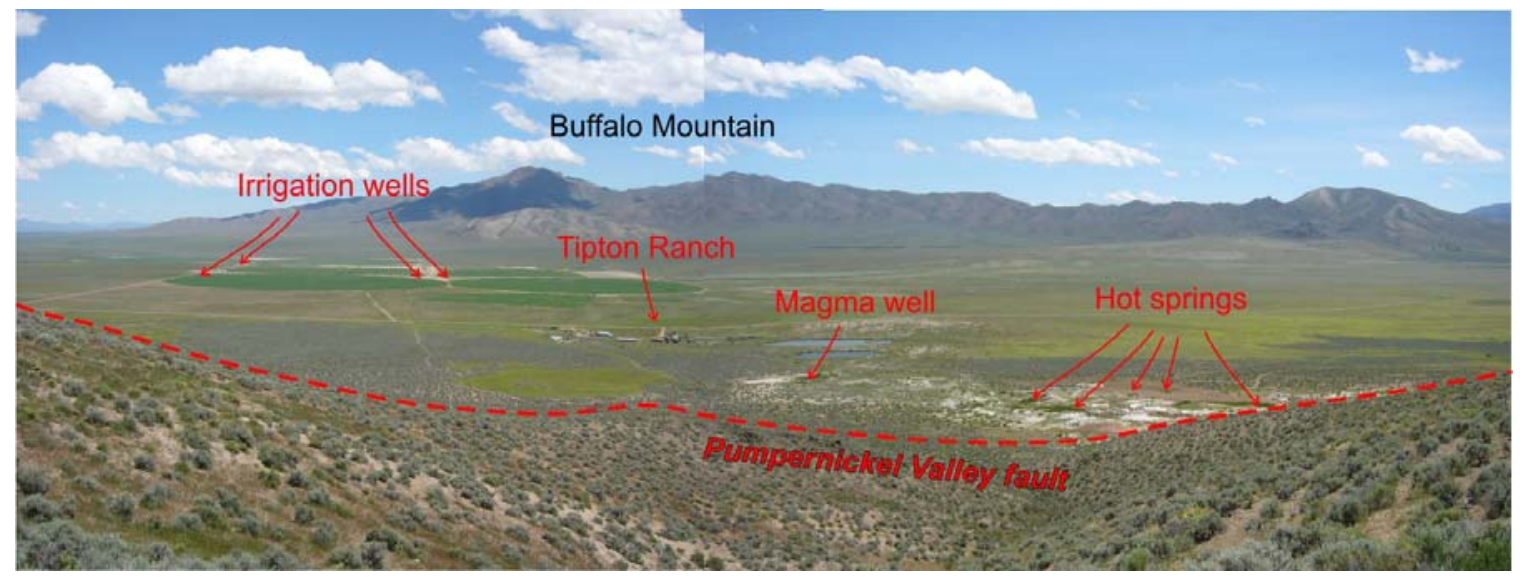

Figure 15. Panoramic view of the Pumpernickel Valley project area looking east from a slope of the eastern Sonoma Range; geothermal features and Tipton Ranch referred to in the text are indicated by red arrows; the red dashed line marks the approximate trace of the Pumpernickel Valley fault. Note the white tufa mound around the hot springs and Magma well.

A smaller cluster of springs and seepages is located along the Pumpernickel Valley fault, south of the main cluster and it represents the southernmost expression of the geothermal system. This area includes a hot spring and creek that flows from it, and a hot seepage. 
A mound of travertine deposit (Figure 16) is present between and near both outflows and indicates that the geothermal activity in this area was more prominent in the past and has been diminished by the recent mining exploration (there are several trenches in this area).

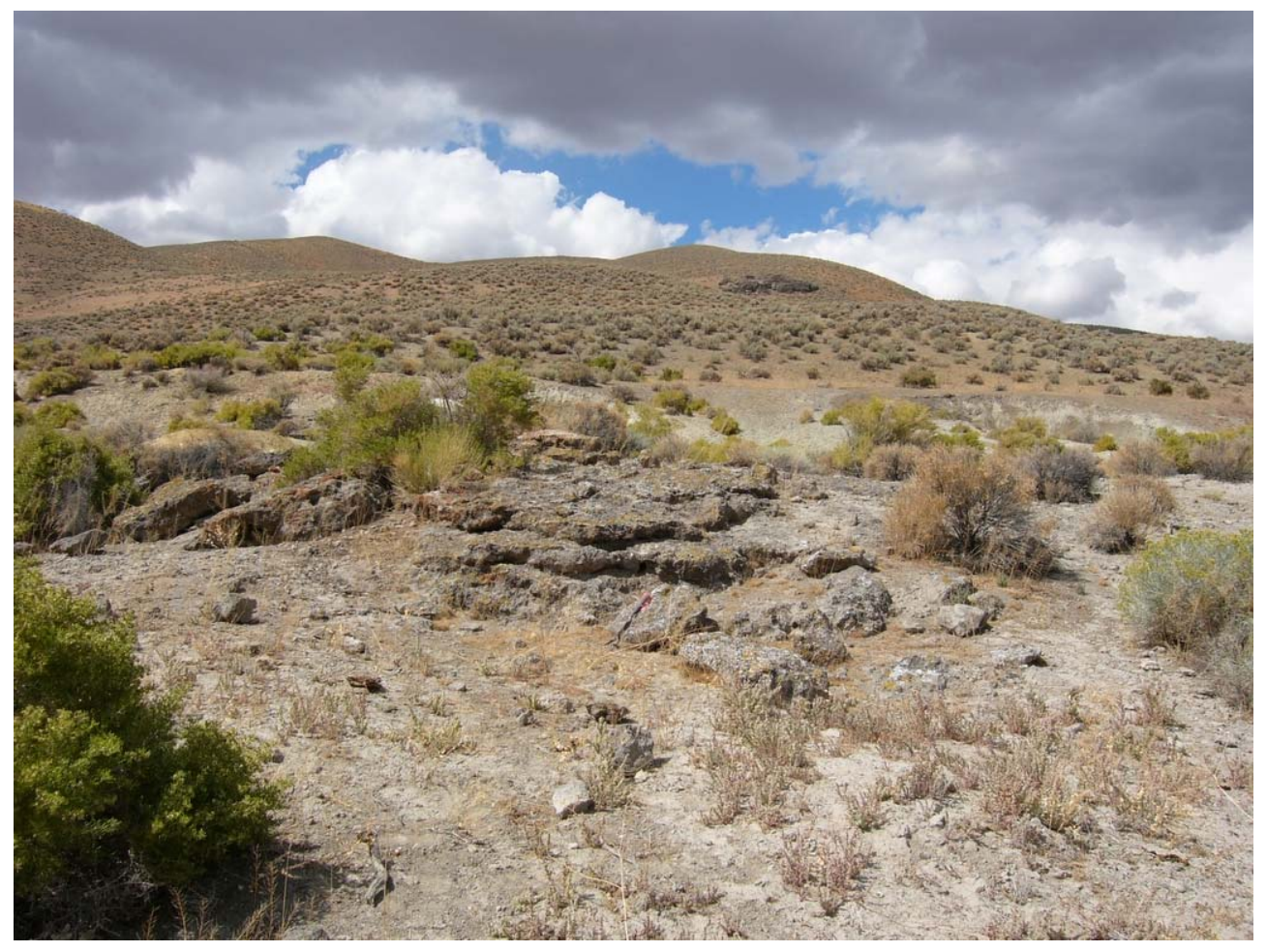

Figure 16. Travertine buildup in the southern cluster of hot springs, on and immediately east of the Pumpernickel Valley fault, indicates a pronounced prior geothermal activity associated with the fault. Looking west.

This area is linked with the larger cluster of springs to the north by a patchy zone of tufa. The spring sinter is mainly calcium carbonate, with some travertine, effloresce, and flower of sulfur. At least one cold spring and two seepages are located in the same area indicating that both geothermal and surface waters utilize the same fault/fracture system associated with the Pumpernickel Valley fault.

Another area located north of the active hot springs and along the trace of the Pumpernickel Valley fault (the northwest corner of section 4) is characterized by an evident halo of strong hydrothermal alteration associated with a fossil spring most likely linked to the currently active geothermal reservoir.

\section{Temperature data}

Almost all hot springs within the main cluster exhibit characteristic banded red-and-green algal mats adjacent to the bare spring vents (Figure 17). This allowed an initial, visual estimate of the temperatures in these springs, since the thermophilic algae live in nonacid waters with temperatures ranging $40-70^{\circ} \mathrm{C}$ (Flynn and Trexler, 1979, and references therein). 


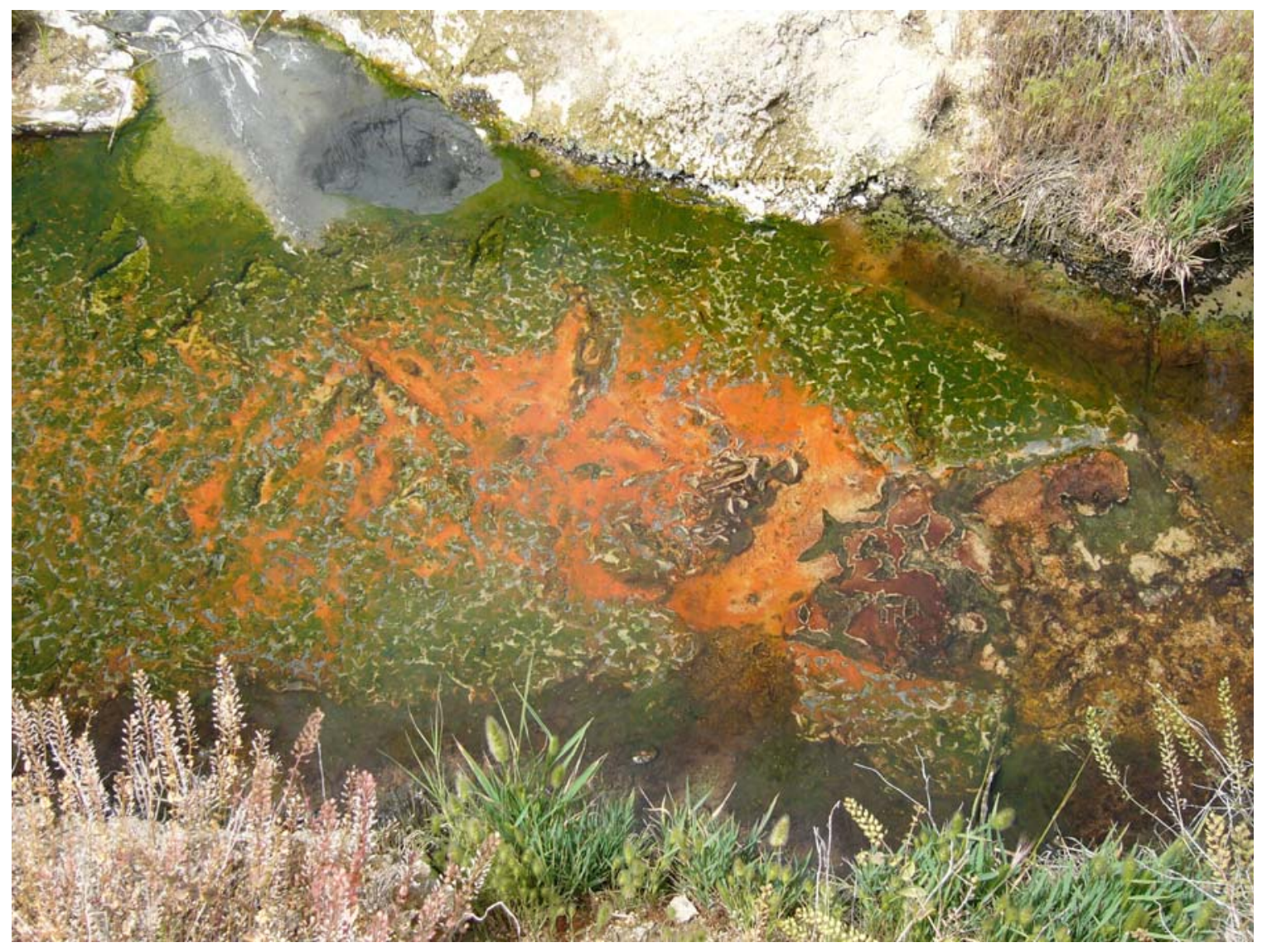

Figure 17. A typical hot spring in Pumpernickel Valley with a vent characterized by no algal growth (top left corner of the photo) and indicative of temperatures higher than $70^{\circ} \mathrm{C}$. The green and orange red banding pattern of algal mats surrounding the vent reflects the configuration of isotherms in the cooling geothermal fluid.

The dark green algae Synechococcus sp. exists in temperatures from $55^{\circ}$ to $70^{\circ} \mathrm{C}$, whereas the orange red Oscillatoria sp. co-exist with the green algae at the low end of its temperature range (op cit). The bulk of the springs on Tipton Ranch have barren zones of no algal growth around spring vents - those are indicative of temperatures higher than $70^{\circ} \mathrm{C}$ (Flynn and Trexler, 1979, and references therein). The striking green and red banding pattern of algal mats surrounding the barren vents in these springs, visible downstream, largely reflects the configuration of isotherms in the cooling geothermal fluids (Figure 17).

\section{Thermistor temperature data}

The temperature data from the springs, seepages, and other water sources were obtained using a calibrated HOBO thermistor having an accuracy of about $0.1^{\circ} \mathrm{C}$. The collected data indicate temperatures in a range from 68 to $88.5^{\circ} \mathrm{C}$ in the main cluster of springs and $94.5^{\circ} \mathrm{C}$ in the wellhead of the Magma well. The temperature recorded in the only hot spring in the southern cluster of springs was $49^{\circ} \mathrm{C}$, whereas the cool spring and nearby seepages have temperatures $18.9^{\circ} \mathrm{C}$ (digital thermometer). 
In contrast, a fresh water seepage associated with a strongly altered dioritic dyke west of the main cluster of springs and the Pumpernickel Valley fault has a temperature of $15.5^{\circ} \mathrm{C}$.

Water in four irrigation wells, each $~ 183 \mathrm{~m}$ deep, in the eastern portion of the project area, have some geothermal component but also a large proportion of meteoric water and lower temperature readings in a range of 20.3 to $22.75^{\circ} \mathrm{C}$.

\section{Resistivity survey}

The E-SCAN ${ }_{\circledast}$ 3D resistivity survey performed specifically within the project area (Shore, 2005) shows a broad resistivity-low anomaly associated with the western portion of the Pumpernickel Valley (Figure 18). Three highly conductive areas, A, B, and C defined the center of the anomaly. The anomaly is bounded by numerous linear features arranged in en echelon mode that form two main trends. One trend is NNE and coincides with the trace of the Pumpernickel Valley fault, whereas the other is WNW and oblique to the main trends of faults in the area. The northern portion of the anomaly is clearly bounded by the Edna Mountain fault as well as linear features parallel and oblique to it. Shore (2005) believes that this anomaly represents an aquifer and the points A and B-C may represent structural feeders.

Several smaller resistivity-low anomalies were also delineated and found to be connected by conductive linear features oblique to as well as parallel to the main trend of the Pumpernickel fault (op cit). Shore (2005) found this pattern of the smaller anomalies to be consistent with that of hydrothermal alteration, whereas the linking conductive features were interpreted as faults with an alteration envelope.

The general aspects of the resistivity survey are supported by the total magnetic field map, produced by the staff of Fairbank Engineering Ltd. 


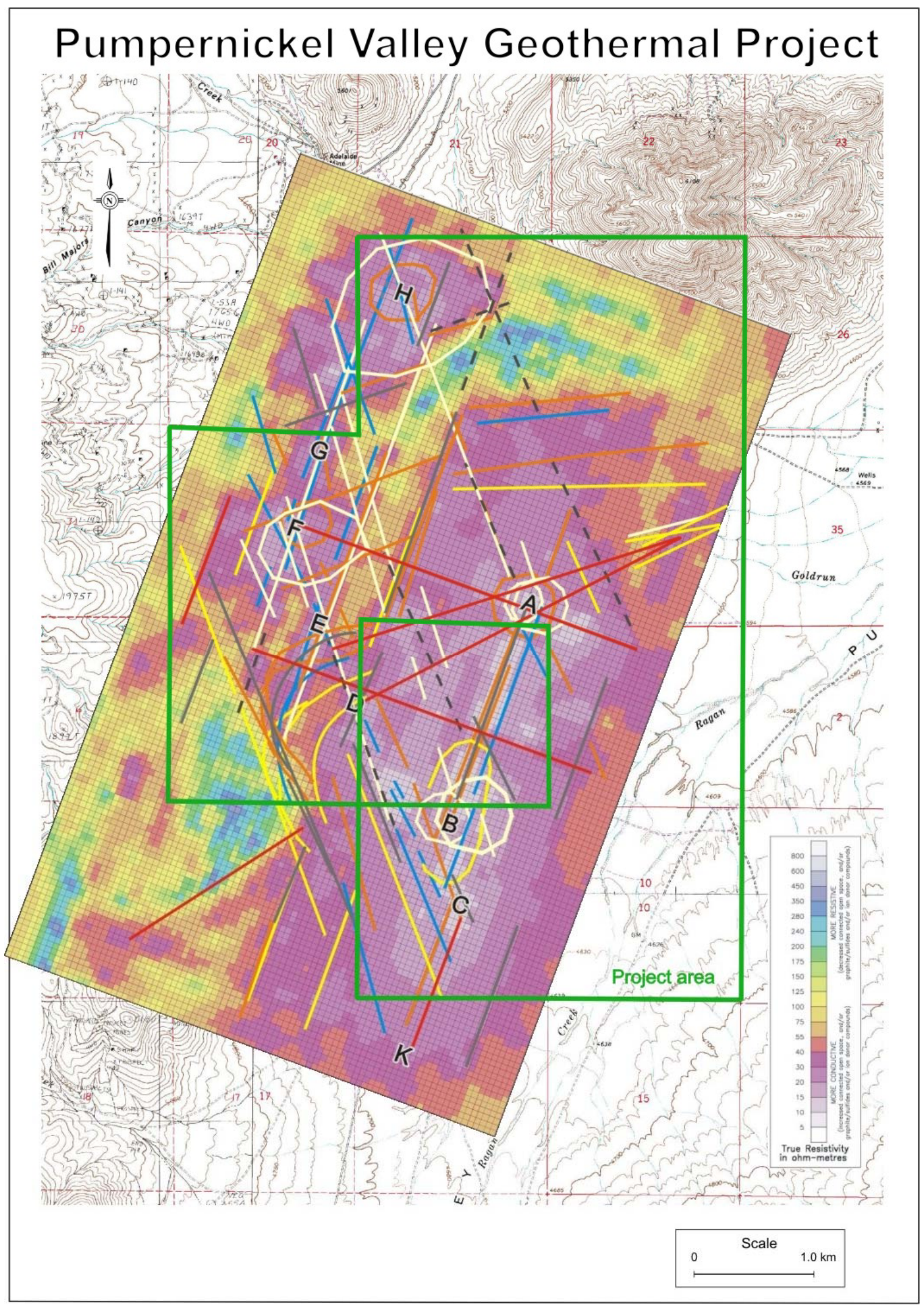

Figure 18. Resistivity map 50 to $75 \mathrm{~m}$ below surface contour from Shore (2005). The letters A through $\mathrm{H}$ represent centers of geophysical anomalies. 


\section{Drilling of the geothermal wells and results}

Nevada Geothermal Power Company (former Noramex, wholly owned subsidiary of Nevada Geothermal Power Inc.) planned to drill 6 geothermal gradient wells, each 250 meters deep, on privately leased land in the Pumpernickel Valley project area.

The final locations of these wells were based in part on the results of the geophysical survey and on geological factors. Only 4 wells were drilled, all of which were deeper than originally planned (Figure 19). The project was completed in approximately 4 weeks and all four wells intersected geothermal fluids.

The thermal gradient wells were drilled as a 'step-out' from the original Magma well and confirmed that the thermal anomaly has a considerable aerial distribution. The wells were drilled vertically, first by air rotary, and then mud drilled to various target depths. One water sample was obtained from each well after the first water horizon was encountered.

\section{Well site locations}

The thermal gradient wells were drilled to map the aerial distribution of the thermal anomaly. The sites, as well as the access routes, were optimally distributed and selected based on the findings of the recent geophysical survey (Shore, 2005) combined with the results of the previous drilling programs (Magma well; Trexler et al., 1982), and geological data (Szybinski, 2005). Additional aspects taken under consideration were: access to existing dirt roads minimizing surface disturbance and the ease of permitting.

From previous drilling and geophysical surveys in the valley, the anticipated maximum depth to overburden in the center of the project area was estimated to be less than $100 \mathrm{~m}$ (Erickson and Marsh, 1978). A recent magnetotelluric survey implied $\sim 400 \mathrm{~m}$ of overburden near the center of the valley (Rodriguez and Williams, 2002). The the 3DESCAN resistivity survey by Shore (2005) also indicated that the geothermal reservoir and related structures are most likely located deeper than previously thought.

Consequently, due to the deeper overburden, the number of holes was reduced from 6 to 4 to allow the depth to be extended to between $300-500 \mathrm{~m}$. The plan was to rotary air drill (by air rotary casing hammer method) to a depth of $\sim 61 \mathrm{~m}$ taking water samples as soon as water horizons were intersected, and then switch to rotary mud drill, taking temperature measurements of the mud returns. If bedrock was attained, drilling would continue for another $150 \mathrm{~m}$.

The final locations of the wells (Figure 19) were within sections 5 and 9 (T33N, R40E), and on section 33 (T34N, R40E). Each location was marked by four corner posts and surveyed for artifacts by the archeologist Robert K. Vierra, PhD of Reno, Nevada. A Negative Cultural Resources Report (BLM Report CR2-2924(N) and an addendum CR22924(P)) was filed with the BLM Winnemucca Field Office. 


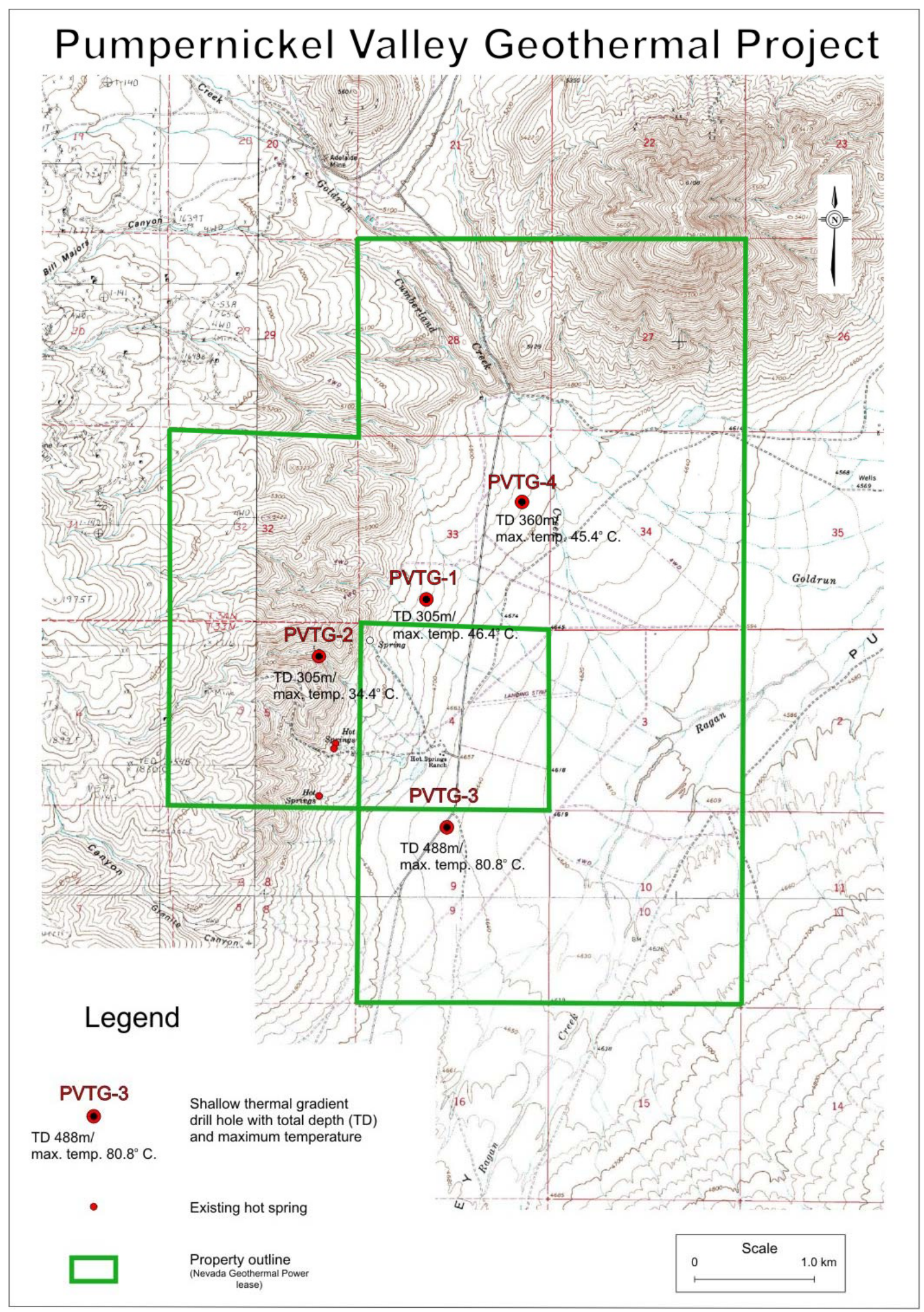

Figure 19. Distribution of the newly drilled geothermal gradient wells within the project area. 
No drill site construction was necessary except for PVTG-2, for which the pre-existing mineral exploration site was modified (Figure 20). Access to PVTG-1 and PVTG-2 was provided by the existing dirt roads or trails.

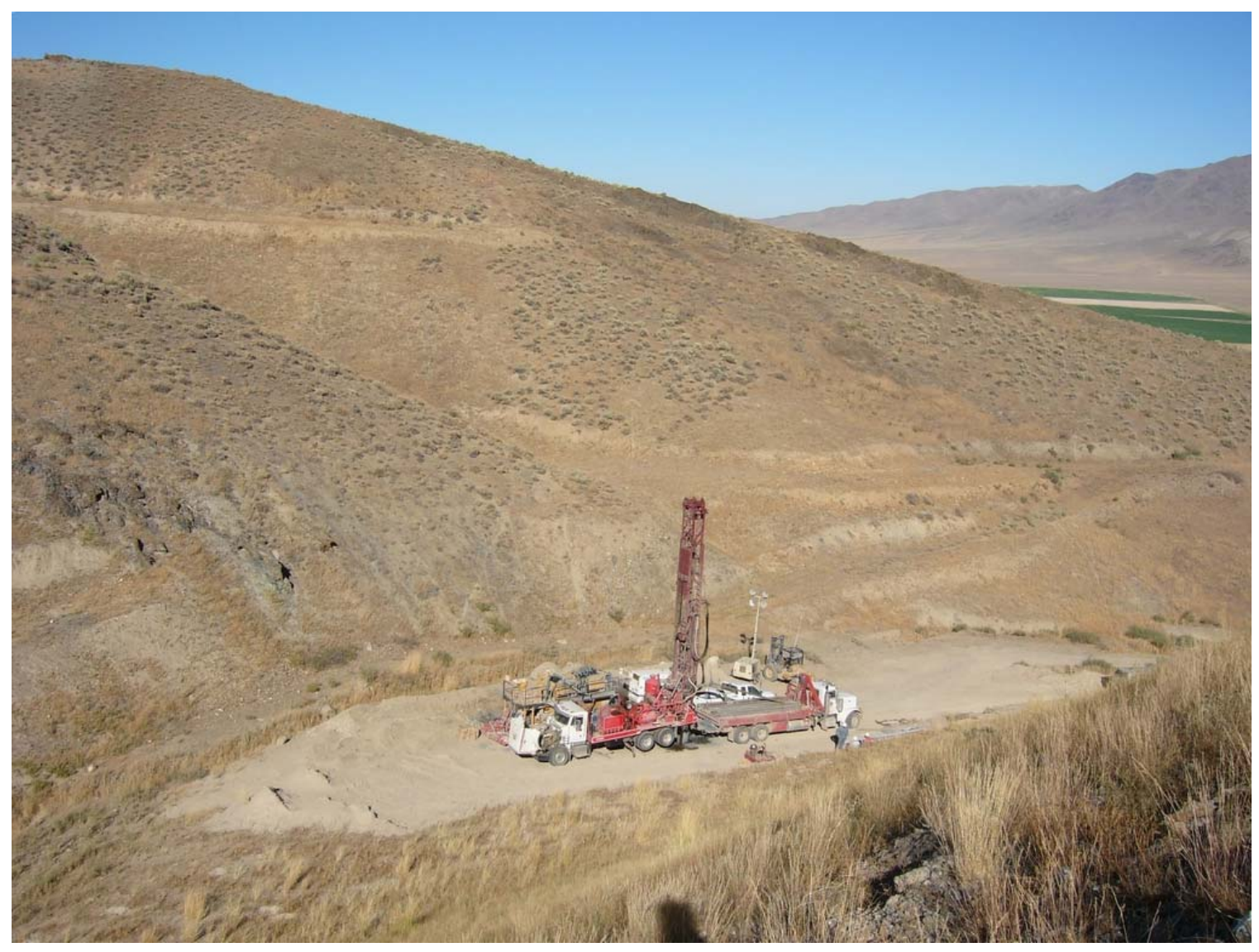

Figure 20. A modified, pre-existing mineral exploration site provided the location for the PVTG-2 borehole. Note the extensive network of trenches in the valley and on hillsides. Looking NE.

Sump pits were excavated at every well site; subsequently they were dewatered and three of these were leveled. The pit on the PVTG-3 site was preserved and is going to be used in the 2006 drilling program. All sites were reclaimed and re-seeded in accordance with state regulations, thus only minimal short-term impacts resulted from this project.

Water for drilling on all sites was trucked in from the well located near the center of the valley (up to approximately $4 \mathrm{~km}$ from the farthest well site, PVTG-4), with the permission of the owners, Bob Brewer and Sarah Rosasco of the Rock Creek Ranch.

The wells were designed as vertical, mud rotary drilled gradient holes only intended to obtain temperature measurements and determine thermal gradients, and no blow-out prevention equipment (BOP) was required. The thermal gradient wells were to be terminated immediately if mud return temperatures reached $80^{\circ} \mathrm{C}$. A water truck (first 6000 gals, and then 4000 gals) was on site to pump cold water down the well if it became necessary to kill the well. Any excess of well fluid or mud was directed to a sump pit. 


\section{Drilling equipment and procedures}

A GEFCO Speedstar 30K Tophead Drive air-casing advance/mud rig (Figure 21) was supplied by WDC Exploration \& Wells of Elko, Nevada. This truck mounted drill rig is able to advance casing while rotating the drill stem and has a pullback capacity 30,000 lbs and top head drive torque of 5,833 ft lbs.

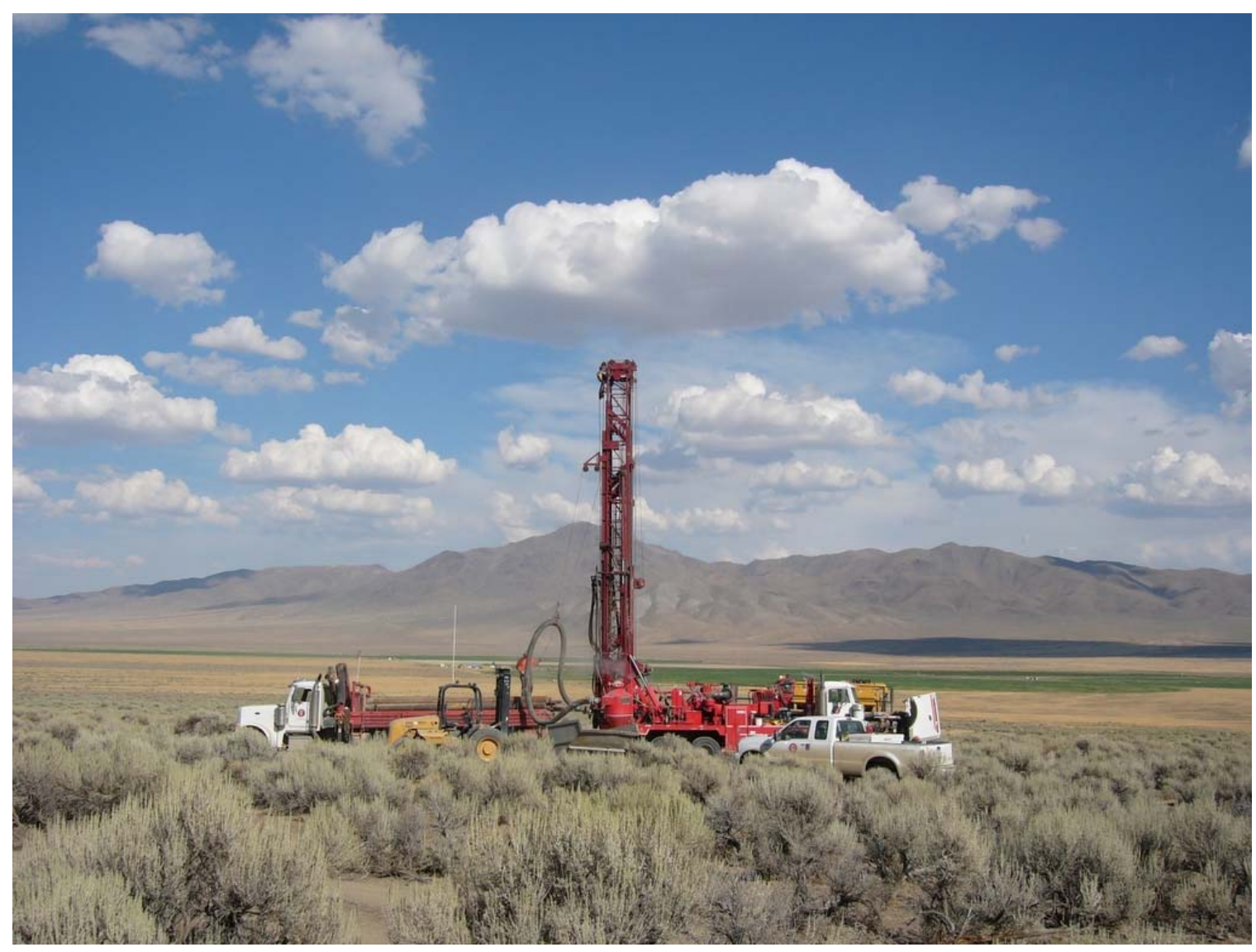

Figure 21. The GEFCO Speedstar 30K Tophead Drive air-casing advance/mud rig used by WDC of Elko, Nevada, to drill all four geothermal gradient holes in the project area. PVTG-1 site, looking ENE.

First the air rotary method was used with air as the drilling fluid to a depth of minimum $61 \mathrm{~m}$. Most of the sections were triconed. The $97 / 8$ or $95 / 8$ inch casing was driven pneumatically in rapid blows into the semi-consolidated overburden in order to prevent the borehole collapse, but was not cemented. The pebbles and/or cuttings were moved out of the hole by the ascending air through the sample hose and into a cyclone (Figure 22), where they were separated from the air.

A minor disadvantage of this method was that pebbles/cuttings in samples were mixed and not always representative of the depth currently being drilled. The advantages included a relatively fast advancement per shift and reasonably easy estimates of water levels. 


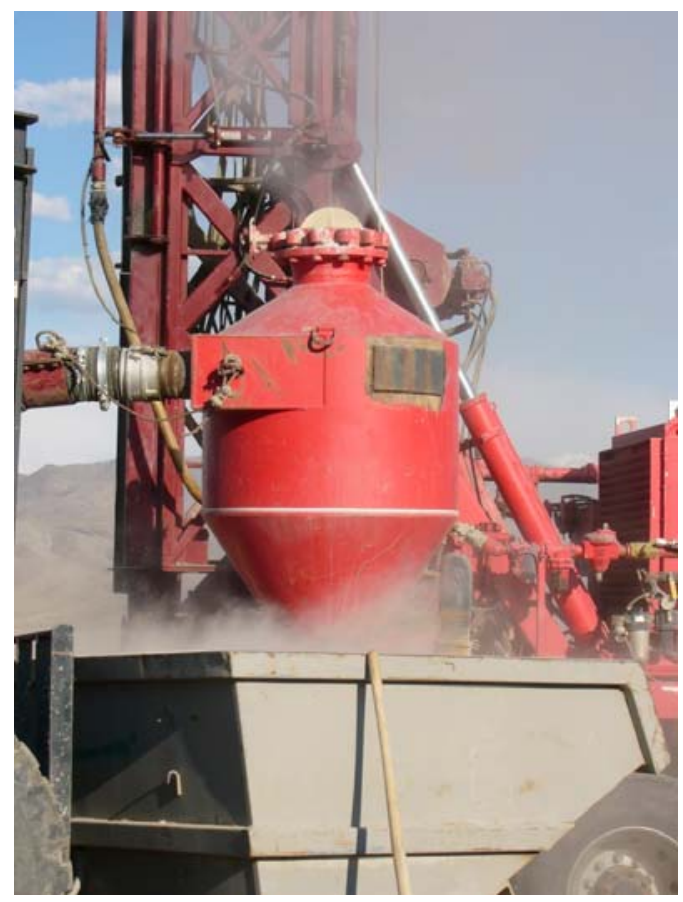

Figure 22. Compressed air carries cuttings back-up the borehole to the surface. The cyclone separator, shown on the left, slows the air velocity and allows the cuttings to be sampled, before they fall into a container.

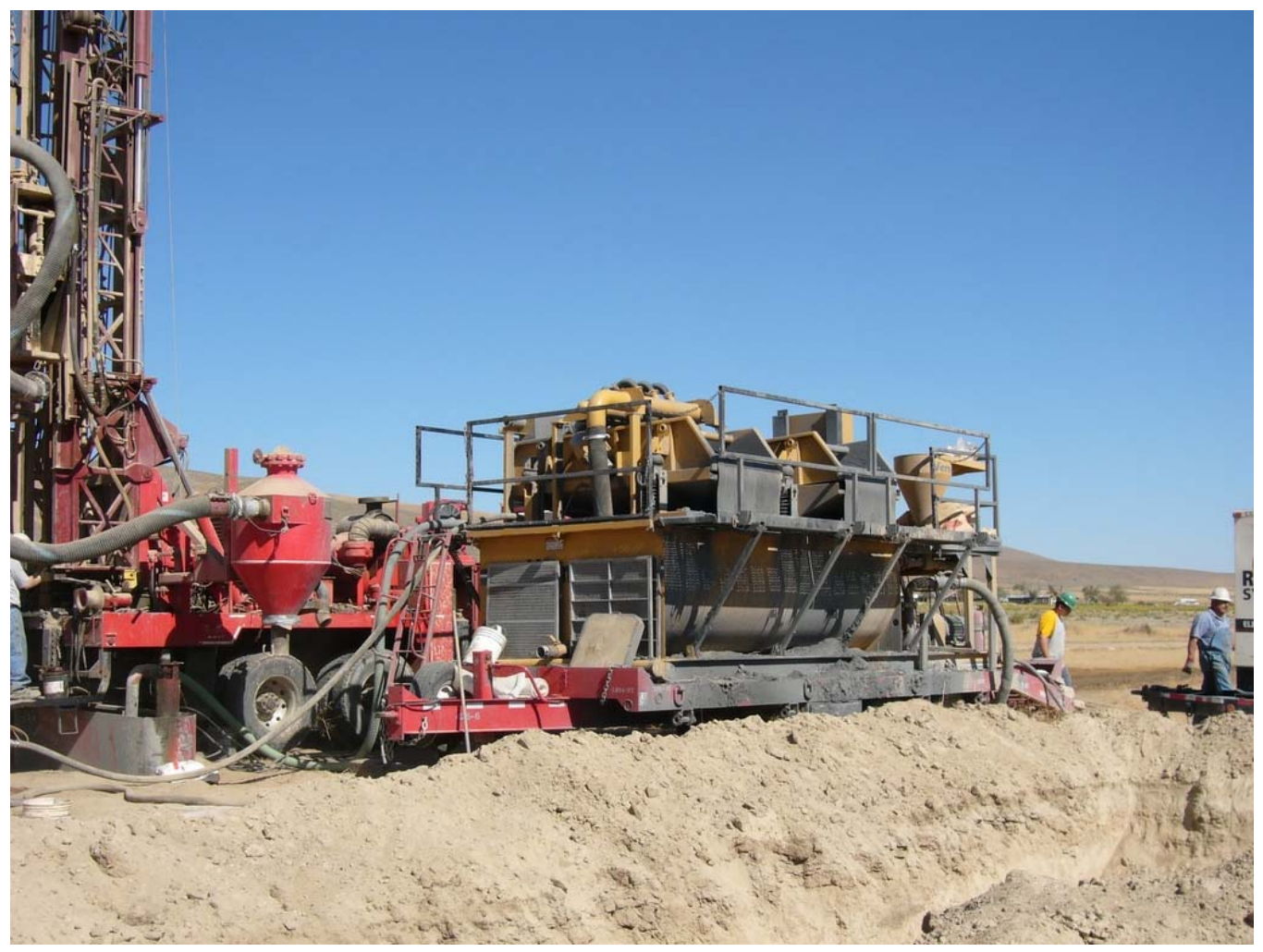

Figure 23. Vibrating screens called shale shakers allow separating the cuttings from the mud; the vibratory action of the shakers moves the cuttings down the screens (two black belts in the center of the device) where they can be sampled, and subsequently moved to the sump pit. PVTG-3 site. 
Subsequently, below $\sim 61 \mathrm{~m}$, the mud rotary method was used in which the rapidly rotating drill bit cut the overburden or rocks and advanced the borehole. The gravel and/or cuttings were removed by drilling fluid (water mixed with mud), which flowed into a shaker (Figure 23) from which the cuttings were constantly moved out to the sump pit, whereas the fluid was pumped back down the drill rods. In addition, the fluid cooled the bits and prevented the drill holes from collapsing in unconsolidated formations below the casing.

Whereas this method is equally fast or faster than air drilling, it had certain disadvantages, which included the inability to immediately determine water levels and to sample them, as well as the loss of circulation and fluid in strongly faulted rocks. Large amounts of the water based drilling fluid flowing in the drill holes caused some difficulties where clays were present. Swelling clays narrowed the hole and plugged drill bits in PVTG-3. Pebbles and/or cuttings are also mixed in this method and don't accurately represent lithologies at a given drilling depth.

PVTG-1 was air drilled to $97.5 \mathrm{~m}$ and the $97 / 8$ ” casing was hammered to this same depth, at which point the rig was converted to mud. The hole, drilled with the Tricone bit 8.5” reached the depth of $305 \mathrm{~m}$, still in overburden. Water with the temperature of $25^{\circ} \mathrm{C}$ was intercepted at $\sim 91.5 \mathrm{~m}$. Drilling fluid with an average viscosity of 48-50 containing bentonite (Kwik-Plug Fine Wyoming Bentonite) and some polymer (polypac) was used. The mud-return temperature reached a maximum of $41.2^{\circ} \mathrm{C}$ near the bottom of this hole.

PVTG-2 was air drilled to 73m, first with the hammer bit 9 7/8” and Stratex shoe, then with the hammer bit 8.5” and conventional shoe, and finally with Tricone bit 7 7/8”. The hole encountered bedrock at $\sim 15 \mathrm{~m}$, first water in fractures at $\sim 20.5 \mathrm{~m}$, and the well was completed to $305 \mathrm{~m}$. The average mud viscosity was $\sim 40$, whereas the maximum-mud return temperature recorded was $40.5^{\circ} \mathrm{C}$ at $\sim 247 \mathrm{~m}$ depth.

In PVTG-3, overburden was deeper than anticipated. The hole did not reach bedrock and the drill rig had reached its capabilities at a depth of $\sim 488 \mathrm{~m}$. It was air drilled first to $\sim 61 \mathrm{~m}$ and at this same time the $97 / 8$ " casing was hammered in; the bit used was Tricone 8.5”. Subsequently the rig was converted to mud and Milltooth Tricone 8.5” and button bit 8.5" were used. The Hobo thermistor temperature recorded at the bottom of well was $\sim 81^{\circ} \mathrm{C}$. The mud viscosity in the upper portion of the hole was 30 and quickly went to maximum 49 at $\sim 330 \mathrm{~m}$, after which it was lowered to $\sim 45$. The maximum mud-return temperature of $48.5^{\circ} \mathrm{C}$ was reached at a depth of $\sim 408-445 \mathrm{~m}$.

PVTG-4, which was originally permitted to $300 \mathrm{~m}$, had its depth extended to $400 \mathrm{~m}$ by filing a "Sundry Notice" with the Division of Minerals (DOM). The hole was air drilled with the Tricone bit 8.5” and casing $95 / 8$ ” hammered in to $\sim 61 \mathrm{~m}$. After conversion to mud, the 7 7/8" Tricone bit was used. Bedrock was intersected at $201 \mathrm{~m}$, but at $\sim 358.5 \mathrm{~m}$ the hole intercepted a major fracture and lost circulation. Attempts to restore the circulation failed and the hole was stopped at 360m. Mud viscosity went from the initial 
35 to 42 at approx. $-150 \mathrm{~m}$ and stayed at $\sim 40-42$ until end of this hole. The mud-return temperature reached a maximum of $38.2^{\circ} \mathrm{C}$ near $-1150 \mathrm{~m}$.

PVTG-1, 2, and 4 were lined with two-inch flush joint black steel pipe, capped at the bottom. The conductor casing was pulled and the annulus was sealed with cement (with an addition of bentonite chips in PVTG-4) to surface. The 2 inch pipes were filled with water, capped, and have been monitored, enabling temperature gradients to be measured over the course of the project. In the PVTG-3 well, the 4.5 inch casing was cemented back to surface in order that it could be deepened at a later date with other drilling equipment. All four wells are locked.

For the well designs and detailed information on the lithology and temperatures see chapters “Geology of the drill holes” and “Temperatures data and gradients”.

\section{Logging}

The author was on the site throughout the drilling operations to log the drill cuttings and coordinate with the drilling staff. Small representative samples of the gravel and/or chips were collected approximately every $3 \mathrm{~m}$, sieved and washed by the geological technician, and examined by the author. A preliminary written description of the cuttings was prepared. Afterwards, the samples were packed in small cotton bags, transported to

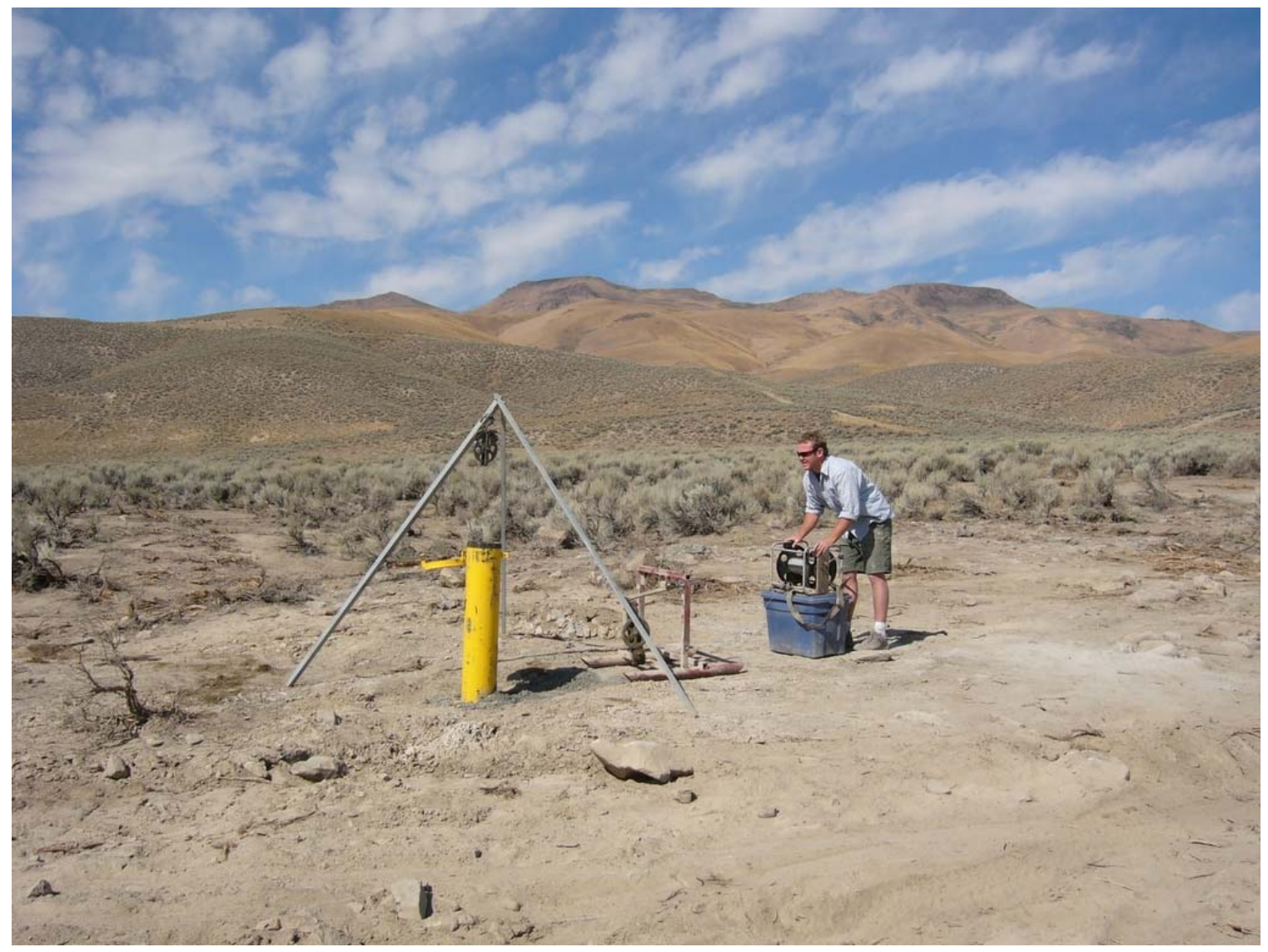


Figure 24. A typical Hobo thermistor setup, which includes wire-line reel, counter, and tripod with downhole pulley. Ryan Nelson during the survey on PVTG-1.

the warehouse located at the Nevada Geothermal office in Winnemucca and dried. Dry samples were split and a portion of each sample was placed in chip trays (plastic boxes with compartments). The samples were examined again under a microscope and tested for effervescence with $10 \% \mathrm{HCl}$, and the drill hole logs were updated. One set of chip samples were sent to the Nevada Bureau of Mines and Geology (NBMG), University of Nevada-Reno.

While drilling, in every hole, the first water encountered was airlifted to surface and sampled for geochemistry, and the water temperature registered. The samples, together with several other samples taken from nearby springs, existing wells, and creeks, were prepared and sent to Thermochem Labs in Santa Rosa, CA for analyses. These samples provided baseline data of the geothermometry of the area. Temperatures of the mud return were monitored using digital thermometers. Once drilling was completed further temperature surveys were taken using the Hobo thermistor probe, provided by Fairbank Engineering Ltd. This yielded detailed temperature gradients and equilibrated temperature profiles after the wells completion (Figure 24).

\section{Geology of the drill holes}

Three out of four holes were drilled in Pumpernickel Valley. The valley geology is dominated by the fill sediments represented by alluvium and piedmont gravels. The alluvium is dominantly Quaternary in age, although there are the late-Tertiary alluvial deposits as well. Where drilled, the thickness of the alluvium ranges from 200m to over 488m, although gravity data (Marsh and Erickson, 1978) suggested alluvial thicknesses may be significantly thinner in the western portion of the project area. The alluvium consists of partially cemented sand, sandy gravel, pebble-gravel and variable, discontinuous deposits of sand, silt, and mud. The alluvial section in the well PVTG-1 also contains thick lenses of tuffs.

The PVTG-1 hole (Figure 25) was located 333m ESE from the Pumpernickel Valley fault and drilled to a total depth of 305m; it didn't reach the bedrock. Water with the temperature of $21^{\circ} \mathrm{C}$ was intercepted at $\sim 61 \mathrm{~m}$. However, the hole intersected two horizons of Tertiary ashflow tuffs (one at least 50m thick) sandwiched between layers of probably clay-supported and partly solidified Tertiary(?) gravel. The pebbles composition in the upper portion of the hole (Ouaternary alluvial deposits) is represented dominantly by the Preble Formation lithologies, though up to $30 \%$ granitic and felsic subvolcanic intrusive rocks are present.

The PVTG-2 hole (Figure 26) was drilled 290m NW from the Pumpernickel Valley fault and drilled to a total depth of $-305 \mathrm{~m}$. Almost the entire length of the hole was in the weakly limey, probably dolomitized and locally siliceous mudstones of the Preble 
Formation. Most of the mudstone is marked by the locally widespread quartz veinlets with minor, various amounts of fine disseminated pyrite. Pyrite also forms a thin film on numerous fractures. Only the first $15 \mathrm{~m}$ of the hole was in the Quaternary alluvial deposits with pebbles and chips of exclusively metasedimentary rocks of the Preble Formation. In this hole, the first water was intercepted in fractures at $-20.5 \mathrm{~m}$, with a better flow at $-30.5 \mathrm{~m}$ and a temperature of $14^{\circ} \mathrm{C}$.

PVTG-3 (Figure 27) was set to test the largest conductivity-high (anomaly B) delineated by the 3D-ESCAN resistivity survey (Shore, 2005). It was located in the southern portion of the project area and drilled to a total depth of $-488 \mathrm{~m}$; it did not reach bedrock. The hole intersected numerous layers of probably clay-supported Quaternary, and subsequently likely Tertiary(?), gravel. Pebble composition in the majority of layers is dominantly, and locally almost exclusively, the Preble Formation, though in the uppermost, mud-drilled Quaternary horizon up to $70 \%$ of the pebbles are of granitic composition and up to $15 \%$ of the pebbles are quartz. Down the hole, the amount of granitic pebbles is significantly smaller and decreasing, and near the bottom of this hole pebbles of volcanic rocks are present and form up to $12 \%$. This relationship may reflect the process of un-roofing of a nearby volcanic/intrusive center, such as the one in Granite Canyon (located $\sim 2 \mathrm{~km}$ due SW from PVTG-3). Chips of pale bluish green and lesser orange siltstone-like rock were found among the gravel near the bottom of the hole and may represent deposition from ascending geothermal fluids and/or alteration of the clays. The first water in this hole was intercepted at $\sim 36.5 \mathrm{~m}$, with a slightly better flow at $42.5 \mathrm{~m}$ and a temperature of $15^{\circ} \mathrm{C}$.

The PVTG-4 hole (Figure 28) was drilled $~ 880 \mathrm{~m} \mathrm{~S}$ from the Edna Mountain fault and $\sim 900 \mathrm{~m}$ E from the Pumpernickel Valley fault, to a total depth of $-360 \mathrm{~m}$. The first $200 \mathrm{~m}$ of the hole is set in several layers of most likely clay-supported Quaternary and Tertiary(?) gravel. Pebble composition in the majority of layers is dominantly, and in some layers almost entirely, of the Preble Formation and Havallah sequence rocks. However, in some layers, up to $20 \%$ of the pebbles are of granitic composition. The other half of this hole is comprised of quartz sandstones, quartzites, and cherts of the Edna Formation. These rocks are variably veined with quartz. At the bottom of this hole, a prominent open fracture is present. Water with a temperature of $21^{\circ} \mathrm{C}$ was intercepted at $-61 \mathrm{~m}$.

The following schematic diagrams from the thermal gradient wells indicate well designs and general down-hole lithology changes. For detailed geologic descriptions refer to the chip logs in Appendix B. 


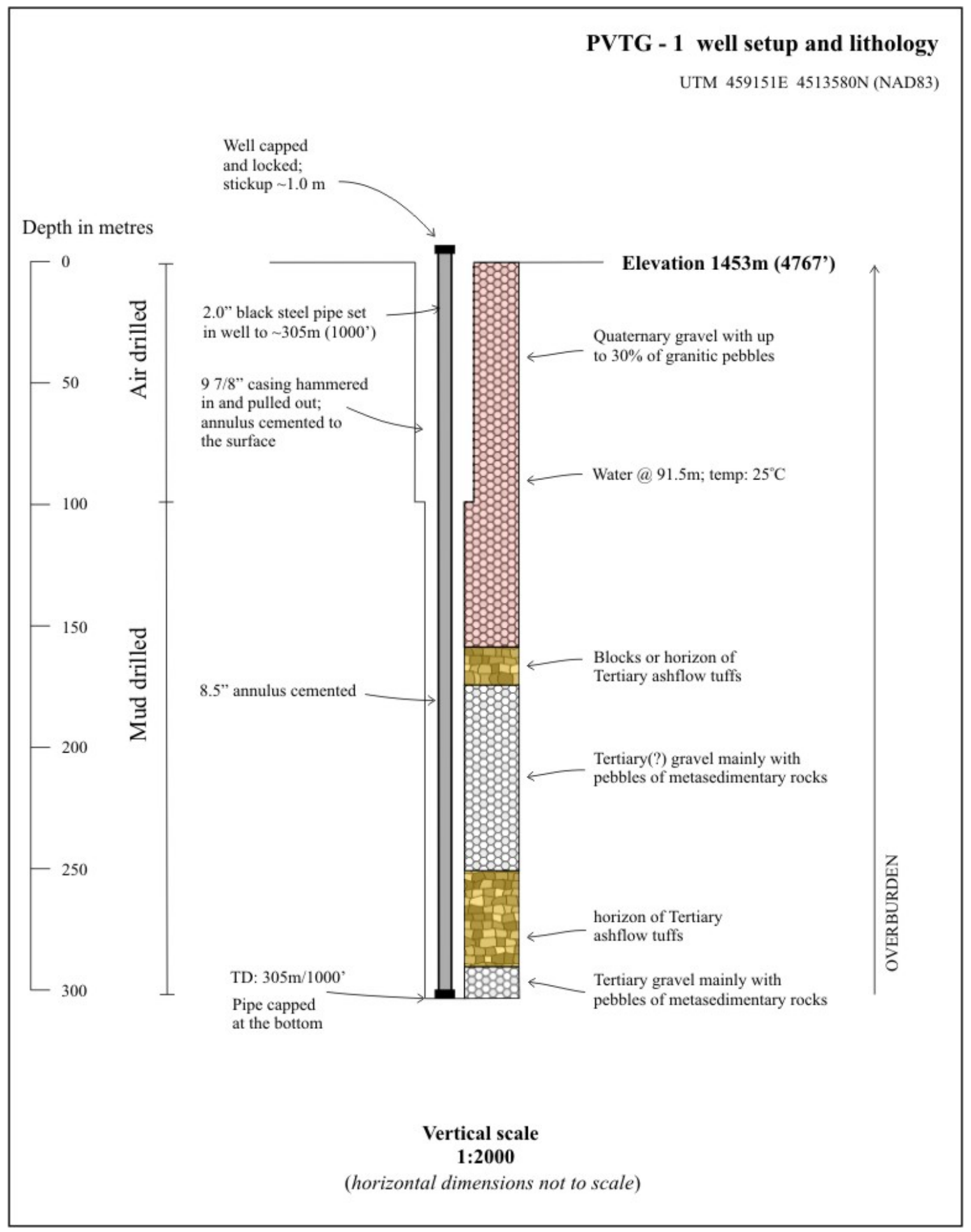

Figure 25. The PVTG-1 well setup and down-hole lithology. 
PVTG - 2 well setup and lithology

UTM 458256E 4513110N (NAD83)

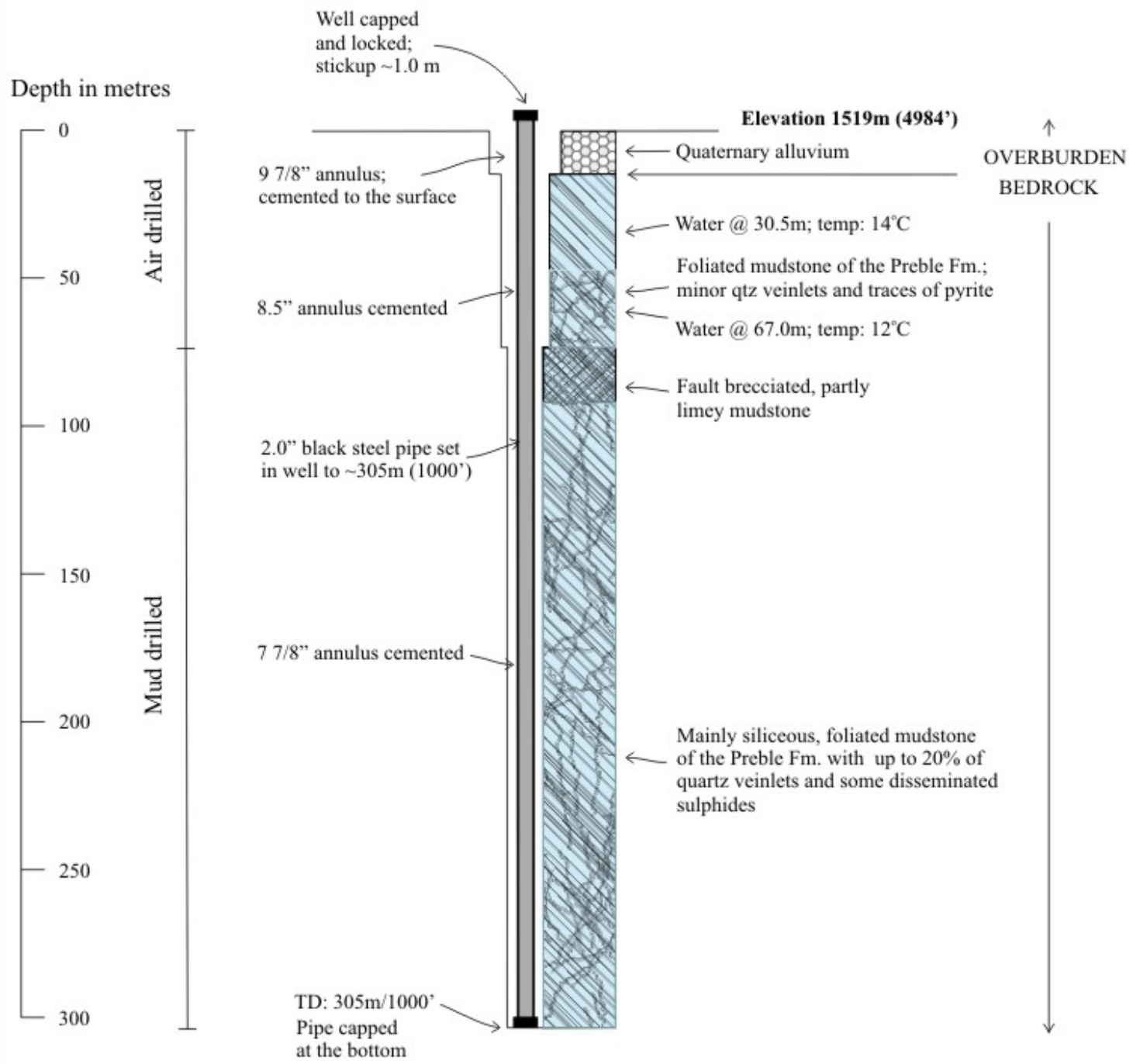

Vertical scale

$1: 2000$

(horizontal dimensions not to scale)

Figure 26. The PVTG-2 well setup and down-hole lithology. 


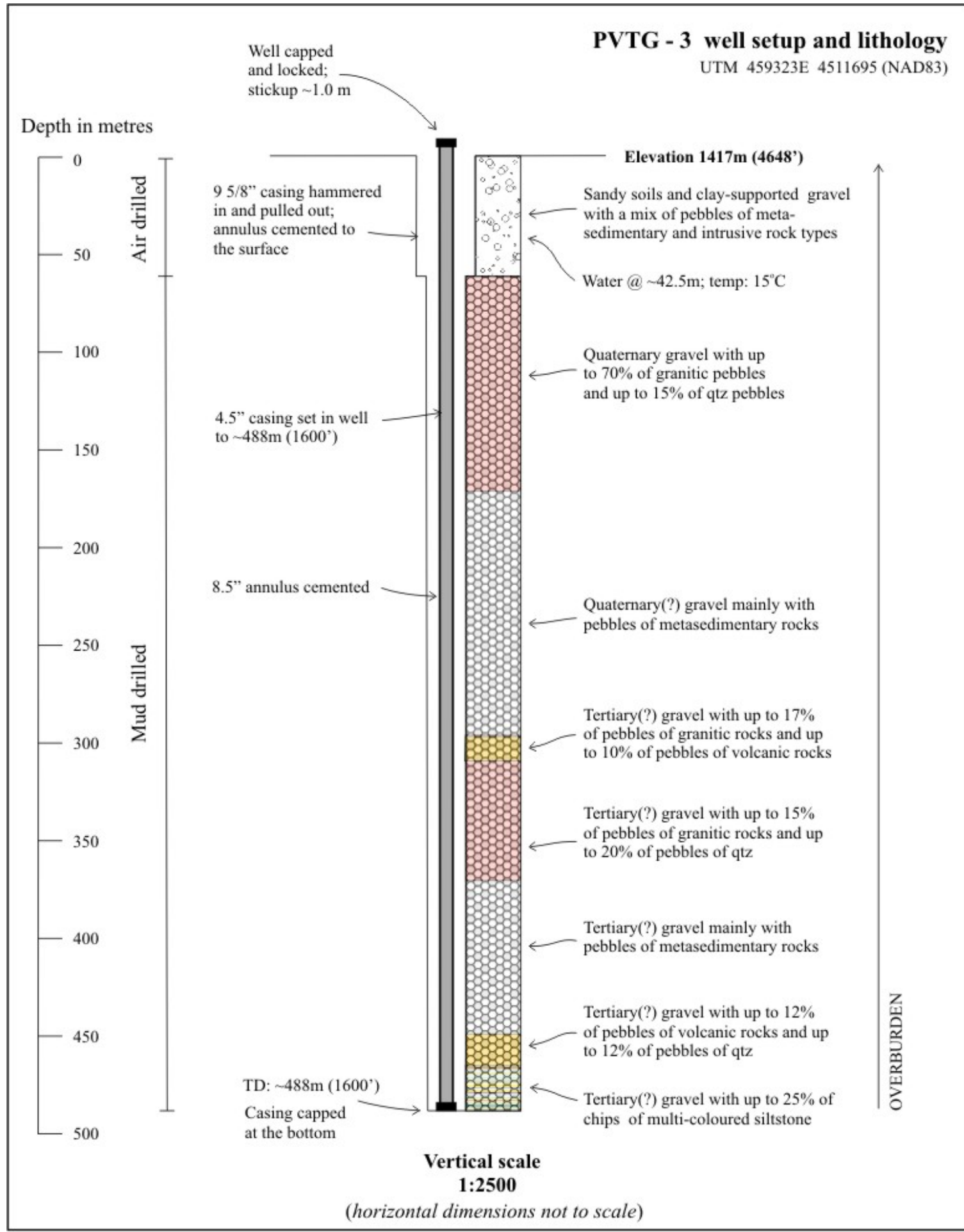

Figure 27. The PVTG-3 well setup and down-hole lithology. 


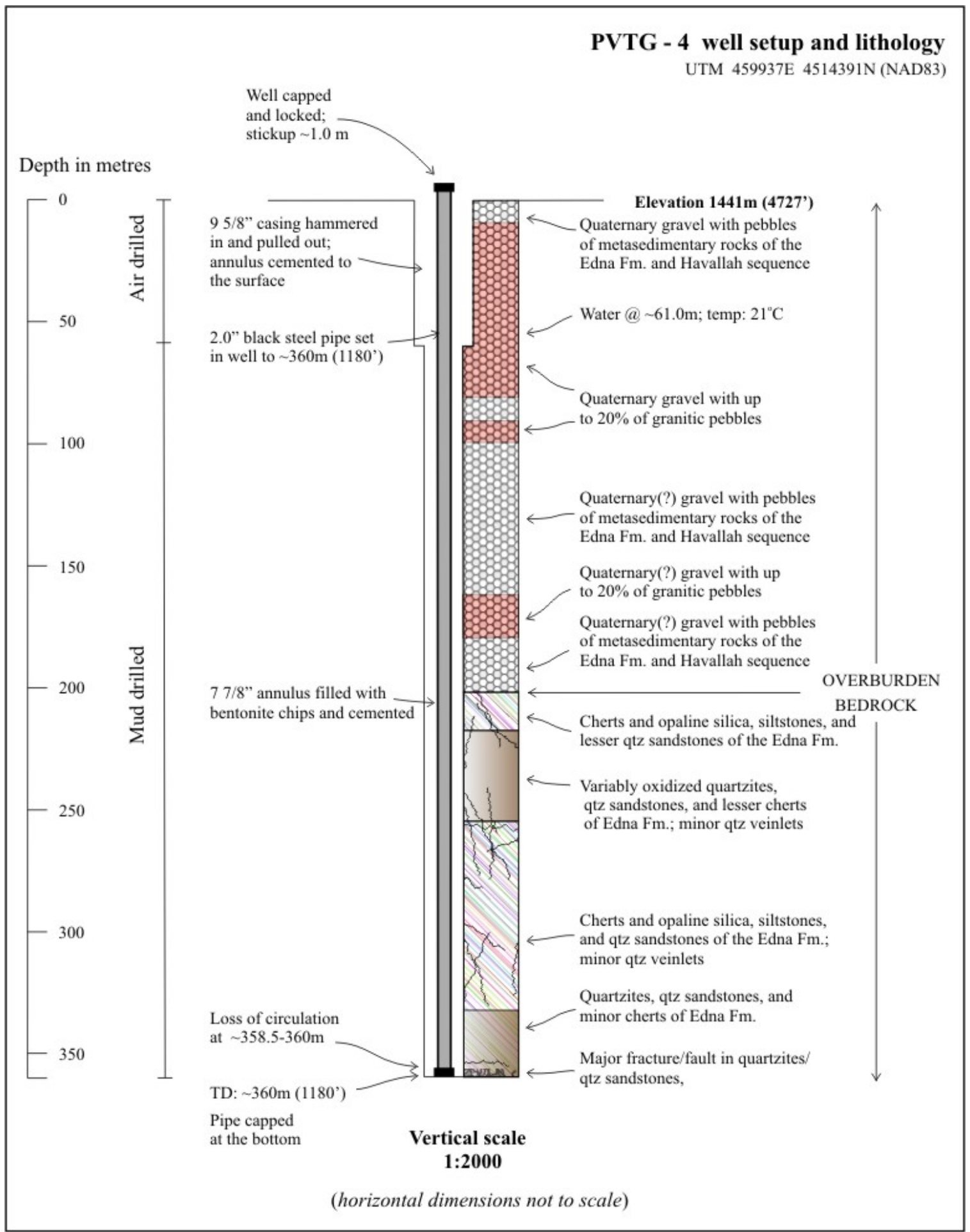

Figure 28. The PVTG-4 well setup and down-hole lithology. 


\section{Temperature data and gradients}

All four wells drilled by Nevada Geothermal Power Company were successful in encountering geothermal fluids. The temperatures from the new temperature gradient holes (Figures 29-32 and Appendix B) and old exploration boreholes (Trexler, 1982) were obtained using calibrated thermistor probes having an accuracy of approximately $0.1^{\circ} \mathrm{C}$. This data was used to calculate the shallow thermal gradients (Sadlier-Brown, 2004; and this work), which are in the range of less than $100^{\circ} \mathrm{C} / \mathrm{km}$ to over $280^{\circ} \mathrm{C} / \mathrm{km}$ (Table 1). However, the available data from the older drill holes, with the exception of the Magma well, is confined to depths less than $100 \mathrm{~m}$ and the geothermal gradient calculated are shallower than those from the Magma and Nevada Geothermal wells.

The Hobo thermistor temperature recorded at the bottom of the PVTG-1 well was $46.4^{\circ} \mathrm{C}$; in the PVTG-2 was $34.4^{\circ} \mathrm{C}$ and was reached at $-305 \mathrm{~m}$; in the hole PVTG-3 the maximum temperature recorded at the bottom of the hole, at $-488 \mathrm{~m}$, was $80.8^{\circ} \mathrm{C}$; and of the PVTG-4 well was $45.5^{\circ} \mathrm{C}$ at $-280 \mathrm{~m}$. The combined data from the old and recent wells appears to define a field of at least 2.0 by $4.0 \mathrm{~km}$ with thermal gradients of $>100^{\circ}$ $\mathrm{C} / \mathrm{km}$ (Figure 33). The geothermal gradients in both the Magma and PVTG-3 holes increase, notably in their lower portions, to $160^{\circ} \mathrm{C} / \mathrm{km}$ (Shevenell and Garside, 2003) and $169^{\circ} \mathrm{C} / \mathrm{km}$ (this report), respectively.

Two generalized colour cross sections through the temperature gradient holes (PVTG) and old exploration boreholes clearly indicate the presence of a major plume of thermal water in the area defined by the wells E, F, and G (Figure 34) and centered on the Pumpernickel Valley fault. The contoured temperature data conform to the expected location of the fault system and indicates that the main plume is controlled, at least in part, by flow from this fault system. This same thermal expression, at a somewhat greater depth, is present within the area between the Magma well and thermal gradient holes PVTG-3 and PVTG-4. The geothermal system almost certainly continues beyond these holes and might be open to the east and south.

With the exception of the PVTG-4, none of the geothermal gradient holes show any indication that temperatures become isothermal or decrease with depth. In PVTG-4, at a depth of $>270$ meters in the cherts and quartzites of the Edna Fm., temperature values begin to taper off, but appear to reverse again after the hole strikes a major fault/fracture.

Clearly, the heat source responsible for the temperatures associated with the plume has not been intersected in any of the Nevada Geothermal Power Company holes and must be at a depth greater than 920 meters (depth of the deepest hole in the project area, the Magma well). 
Nevada Geothermal Power Inc. and Inovision Solutions Inc.

PVTG - 1 well setup and temperatures

UTM 459151E 4513580N (NAD83)

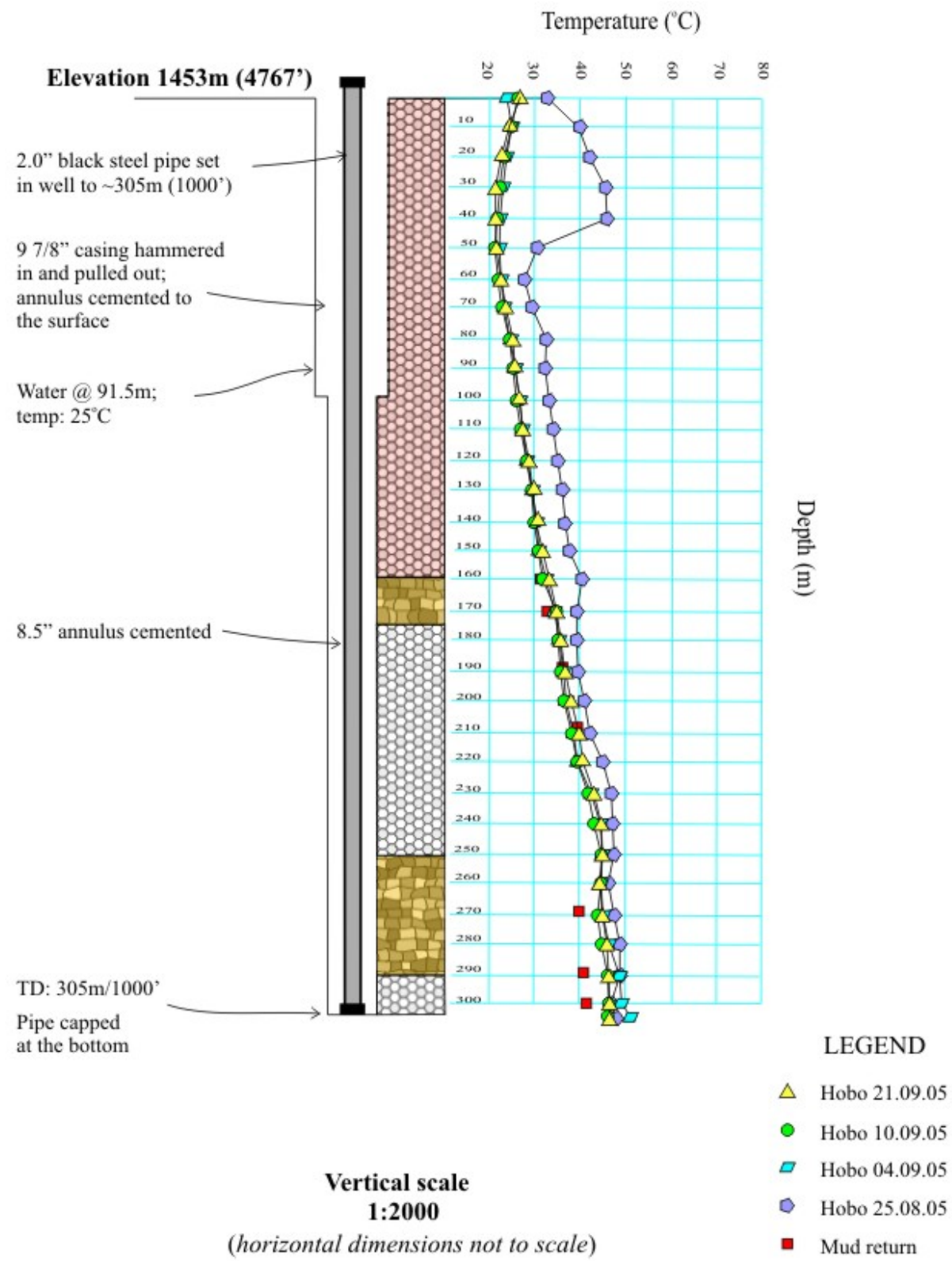

Figure 29. The PVTG-1 well setup and down-hole lithology vs.temperature profiles. 
PVTG - 2 well setup and temperatures

UTM 458256E 4513110N (NAD83)

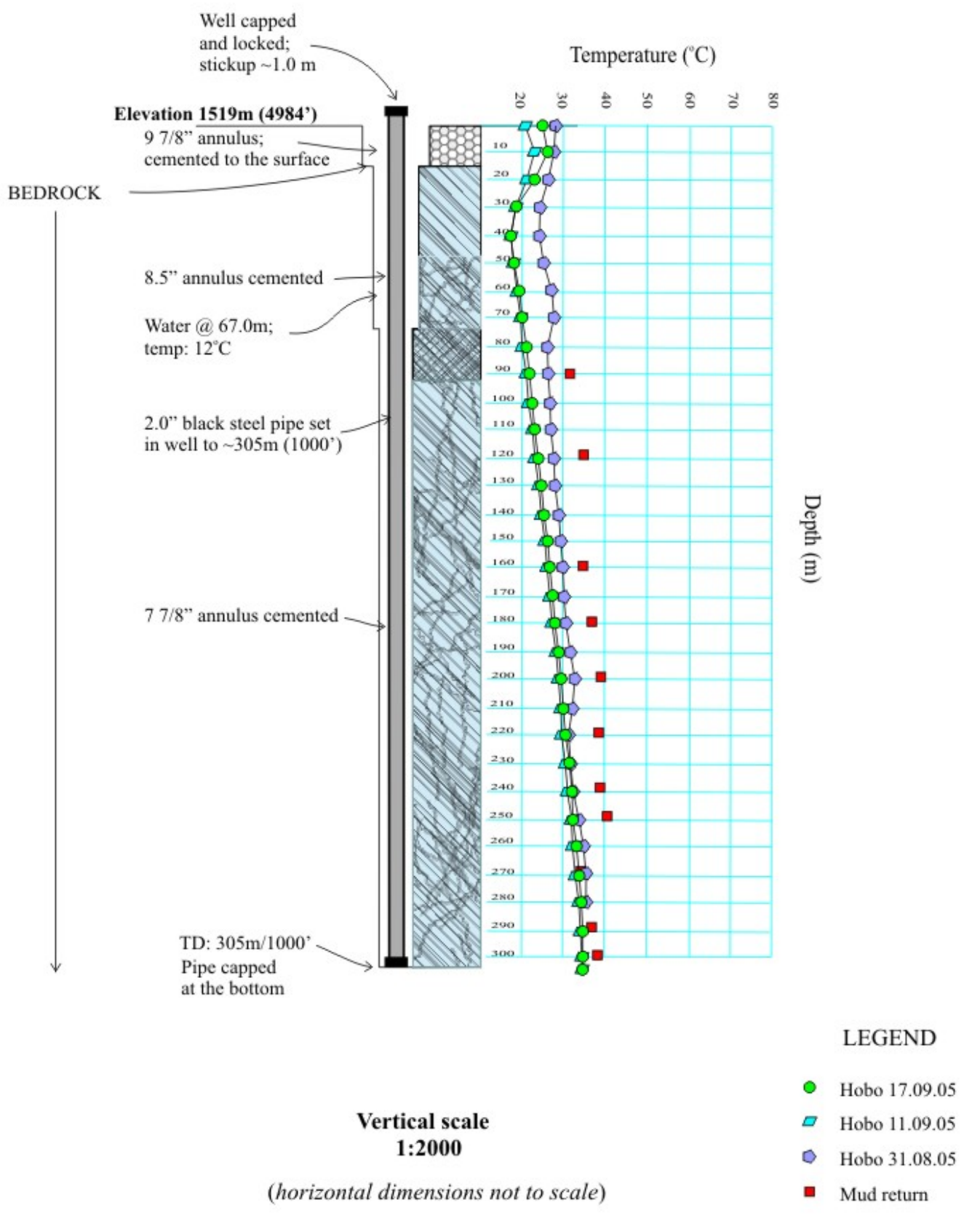

Figure 30. The PVTG-2 well setup and down-hole lithology vs.temperature profiles. 


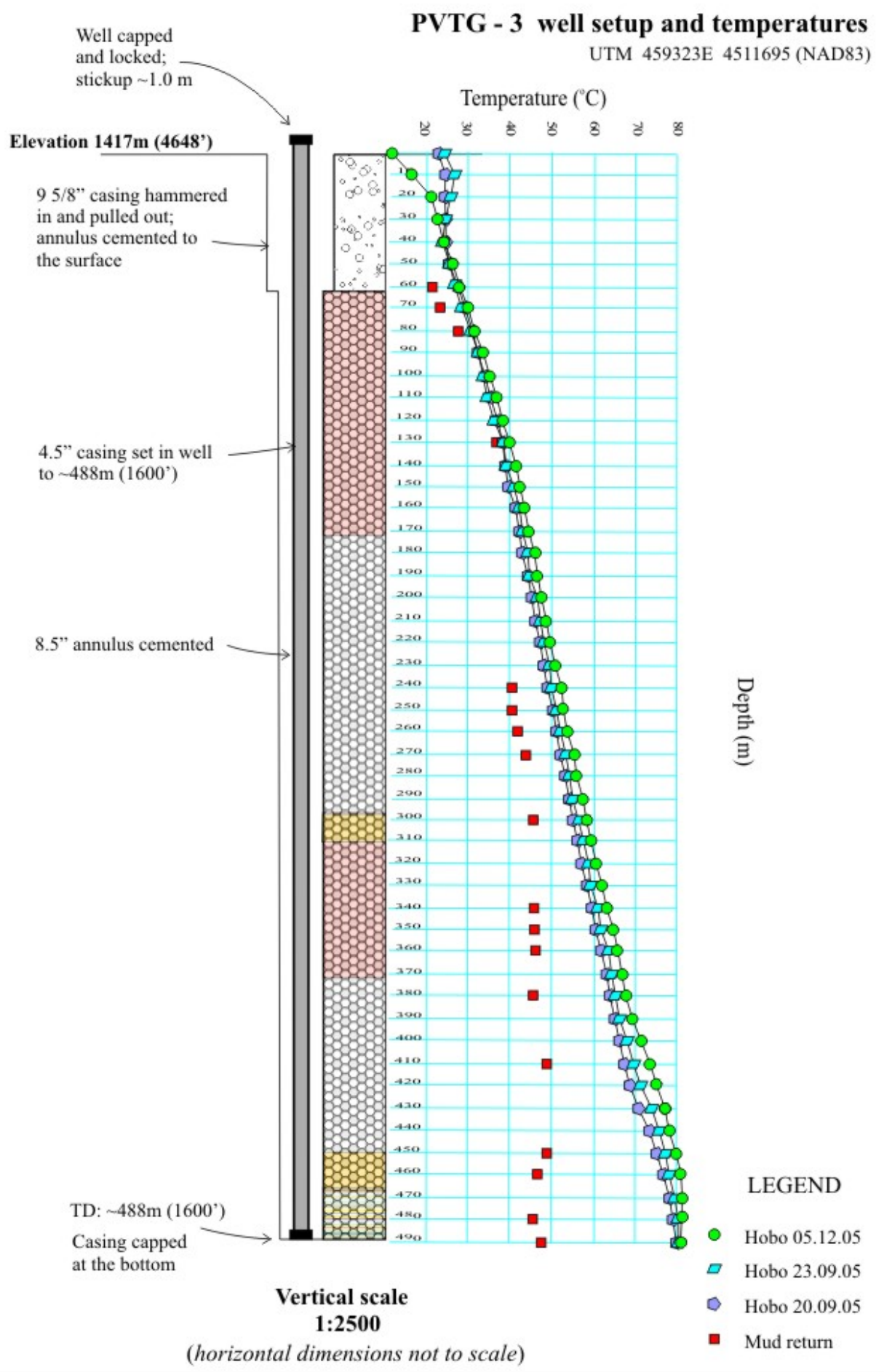

Figure 31. The PVTG-3 well setup and down-hole lithology vs.temperature profiles. 


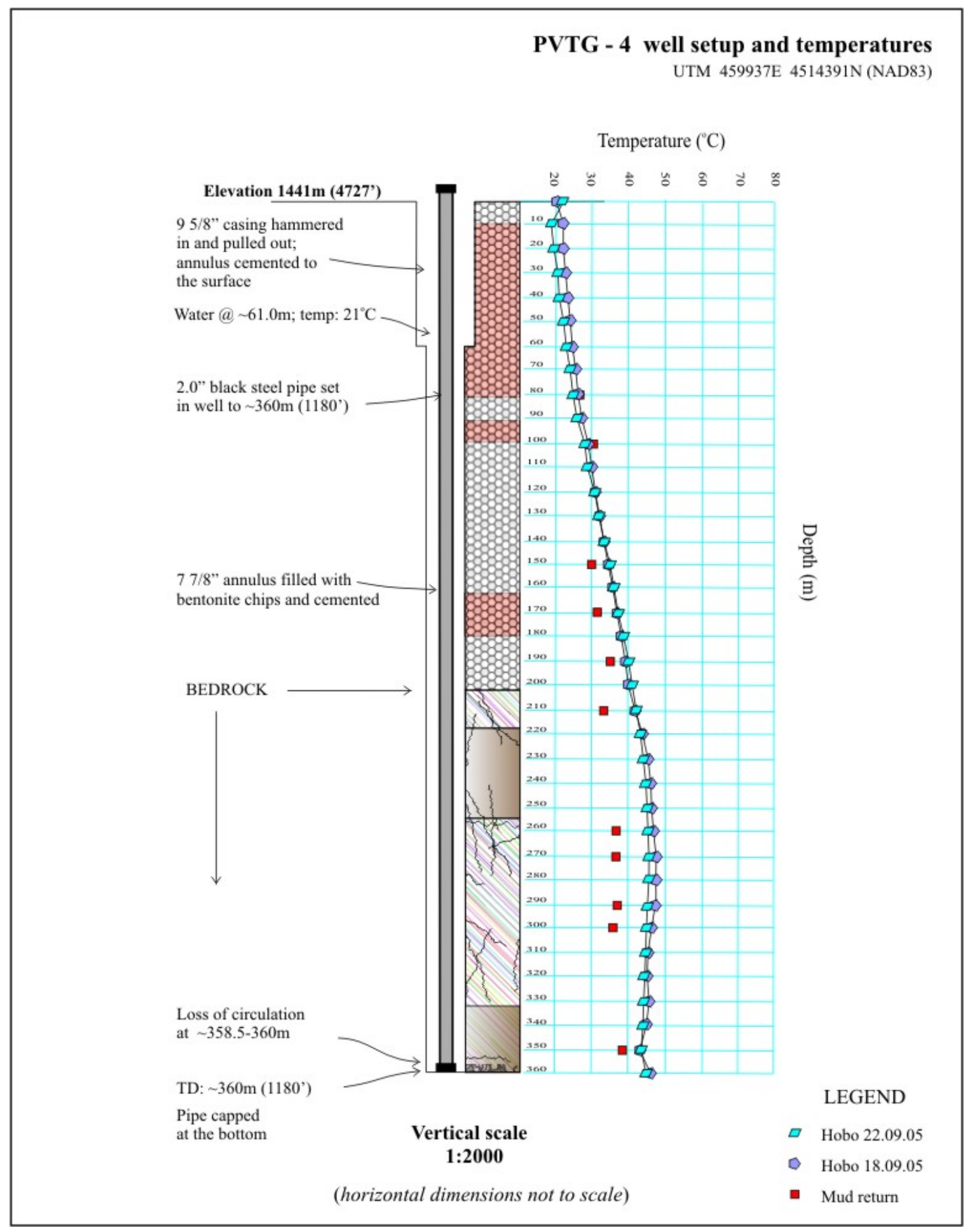

Figure 32. The PVTG-4 well setup and down-hole lithology vs.temperature profiles. 


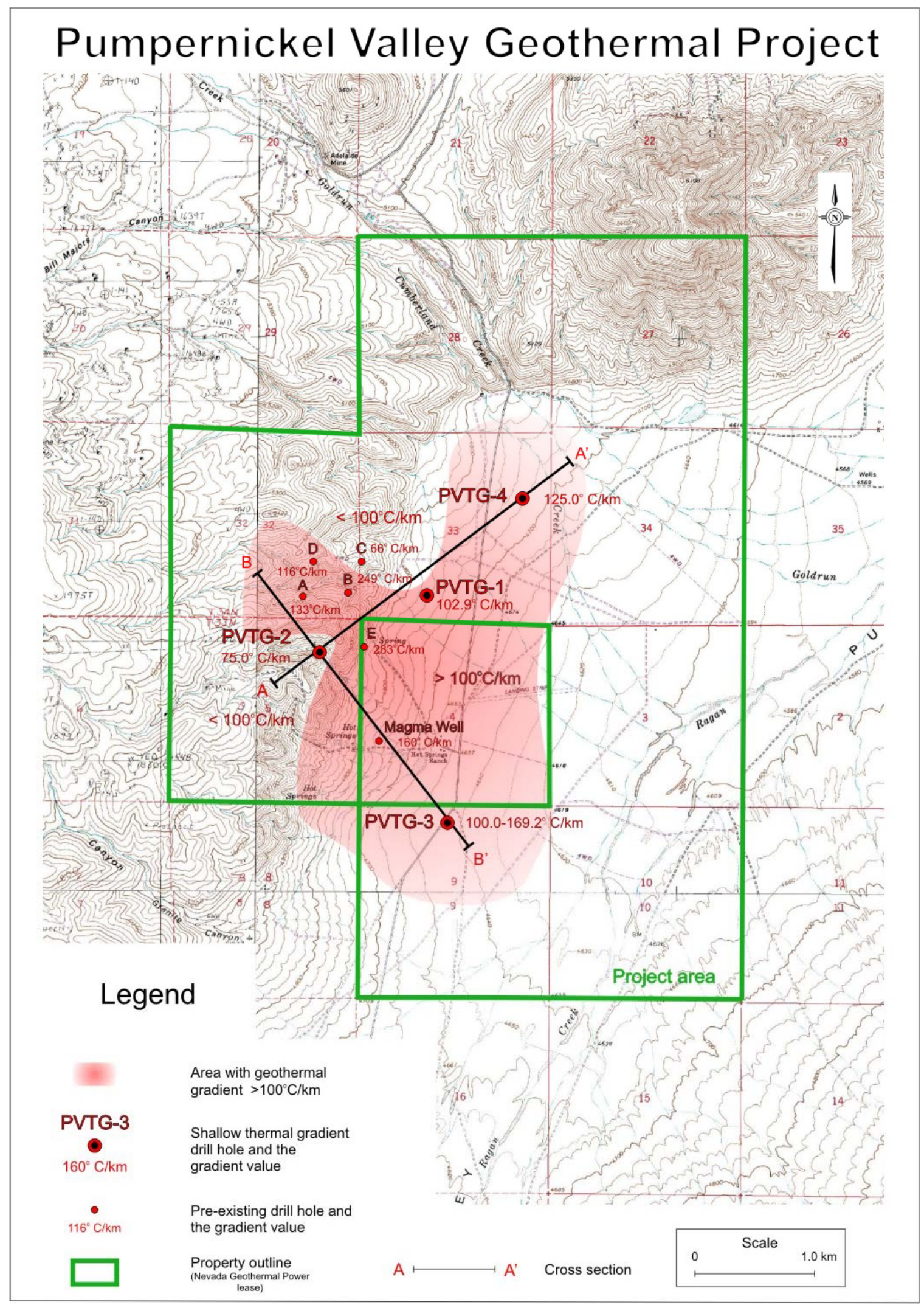

Figure 33. Pumpernickel Valley geothermal system - area with geothermal gradient $>100^{\circ} \mathrm{C} / \mathrm{km}$. 


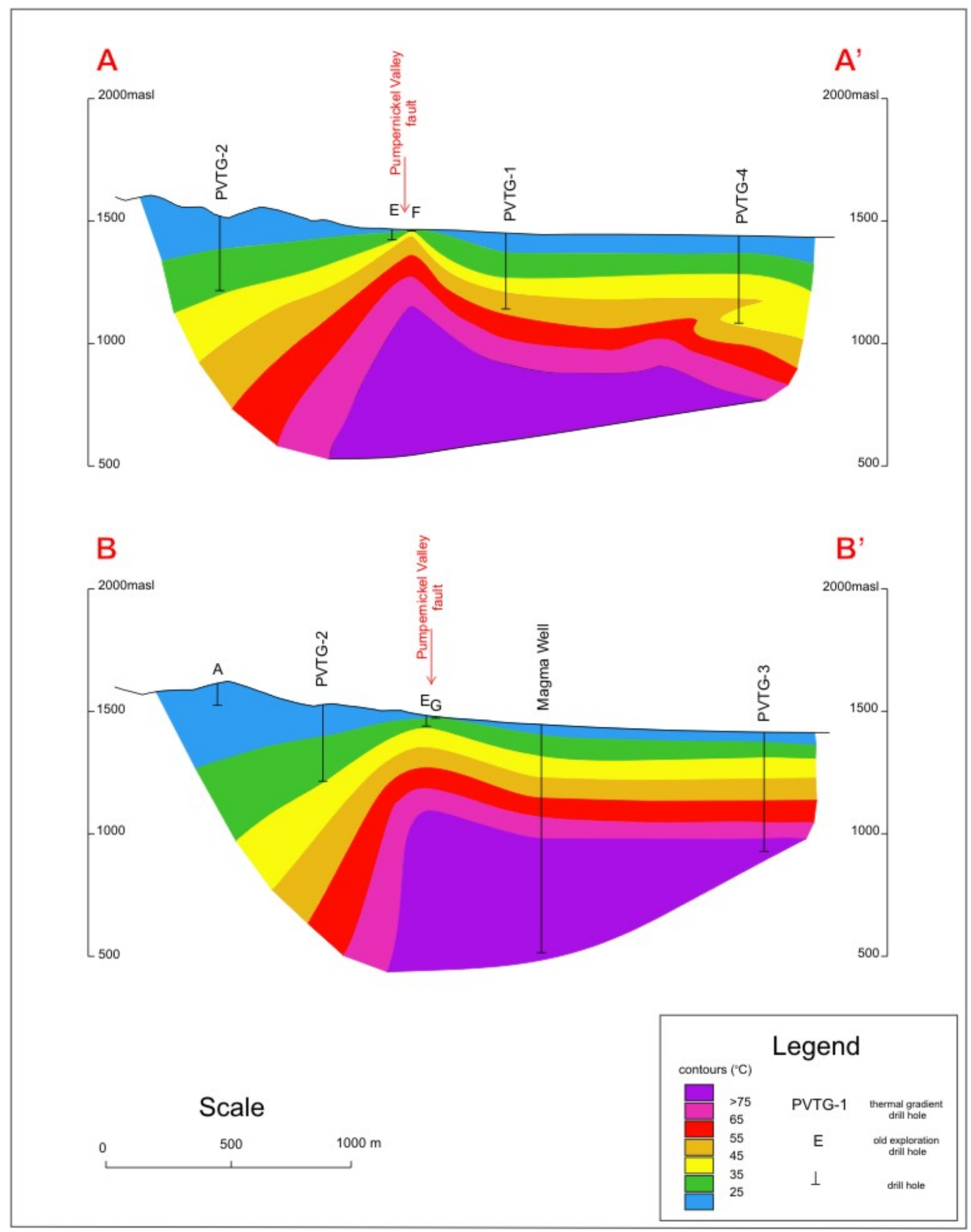

Figure 34. Pumpernickel Valley geothermal system; generalized temperature cross sections A-A' and BB' based on the well data and extrapolated at depth. For the cross section locations see Figure 33. 


\section{Geochemistry}

The brine from the drill holes, hot springs, seepages, and irrigation wells was sampled, as well as water from two nearby creeks, (total of 13 samples) and sent for analysis to Thermochem Inc. For sample locations refer to Figure 35; the geochemical data are presented in Appendix C.

Geochemical results indicate the presence of two distinct waters in this group of samples (Tom Powell of Thermochem Inc., personal communication, 2005). Powell found that $\mathrm{MDH}$, TRS-1 and TRS-6 are the most prospective waters and tend to be more bicarbonate rich with much higher proportions of $\mathrm{B}, \mathrm{Li}$ and much lower $\mathrm{Cl}$. They are clearly related, and all have the same $\mathrm{Cl}$ concentration but vary in the other constituents.

Table 1. Geochemical Geothermometers (calculated by Tom Powell of Thermochem Inc.). Samples PVTG-1 to -4 are from the geothermal gradient holes; MDH is from the Magma well; TRS-1 and TRS-6 are from hot springs; TRS-5 is a fresh water seepage; BB2 and BB4 are from irrigation wells; PVS-2 from the Goldrun Creek; PVS-4 from a cold spring; and PVS-5 from a creek.

\begin{tabular}{|l|c|c|c|c|c|c|c|}
\hline $\begin{array}{c}\text { Sample } \\
\text { Name }\end{array}$ & $\begin{array}{c}\text { T } \\
\text { Chalce- } \\
\text { dony }\end{array}$ & $\begin{array}{c}\text { T } \\
\text { Quartz } \\
\text { cond. }\end{array}$ & $\begin{array}{c}\mathbf{T} \\
\text { Na-K-Ca }\end{array}$ & $\begin{array}{c}\mathbf{T} \\
\text { Na-K-Ca } \\
\text { Mg corr. }\end{array}$ & $\begin{array}{c}\mathbf{T} \\
\text { Na/K } \\
\text { (Giggen- } \\
\text { bach) }\end{array}$ & $\begin{array}{c}\mathbf{T} \\
\text { K/Mg } \\
\text { (Giggen- } \\
\text { bach) }\end{array}$ & $\begin{array}{c}\text { T } \\
\text { Anhydrite }\end{array}$ \\
\hline PVTG-1 & 40 & 73 & 147 & 69 & 205 & 60 & 120 \\
\hline PVTG-2 & 43 & 76 & 168 & 78 & 265 & 58 & 120 \\
\hline PVTG-3 & 35 & 67 & 108 & 65 & 132 & 51 & 136 \\
\hline PVTG-4 & 22 & 54 & 158 & 113 & 206 & 83 & 169 \\
\hline MDH & 139 & 163 & 175 & 145 & 220 & 105 & 167 \\
\hline TRS-1 & 134 & 159 & 185 & 168 & 219 & 122 & 195 \\
\hline TRS-6 & 103 & 131 & 179 & 109 & 233 & 94 & 145 \\
\hline TRS-5 & 49 & 81 & 141 & 64 & 222 & 42 & 99 \\
\hline BB2 & 48 & 80 & 131 & 64 & 201 & 40 & 155 \\
\hline BB4 & 51 & 83 & 128 & 69 & 191 & 42 & 142 \\
\hline PVS-2 & 42 & 74 & 122 & 54 & 178 & 39 & 135 \\
\hline PVS-4 & 27 & 59 & 148 & 80 & 238 & 46 & 121 \\
\hline PVS-5 & 61 & 93 & 166 & 54 & 247 & 59 & 215 \\
\hline
\end{tabular}

Powell also concluded that the "best water" is TRS-1 (from the spring located near the Pumpernickel Valley fault). "Low temperature geothermometers (K-Mg, chalcedony) range from $120^{\circ} \mathrm{C}(\mathrm{K}-\mathrm{Mg})$ to $140^{\circ} \mathrm{C}$ (chalcedony). $\mathrm{Na} / \mathrm{K}$ trends to $220^{\circ} \mathrm{C}$, suggesting that the source water may achieve this temperature and then pick up $\mathrm{Mg}$ and $\mathrm{Ca}$ on its way to the surface. High Mg is a characteristic of bicarbonate waters, perhaps because they are mildly acidic and would tend to dissolve local rocks. This would drive the K$\mathrm{Mg}$ geothermometer down and might make the waters look cooler than the actual source. The trend of the 3 waters suggests that they have picked up Ca and SO4 on their way to the surface, lowering the anhydrite geothermometer for the TRS-6 water. This might be expected in arid valley fill, with evaporite gypsum present.” 


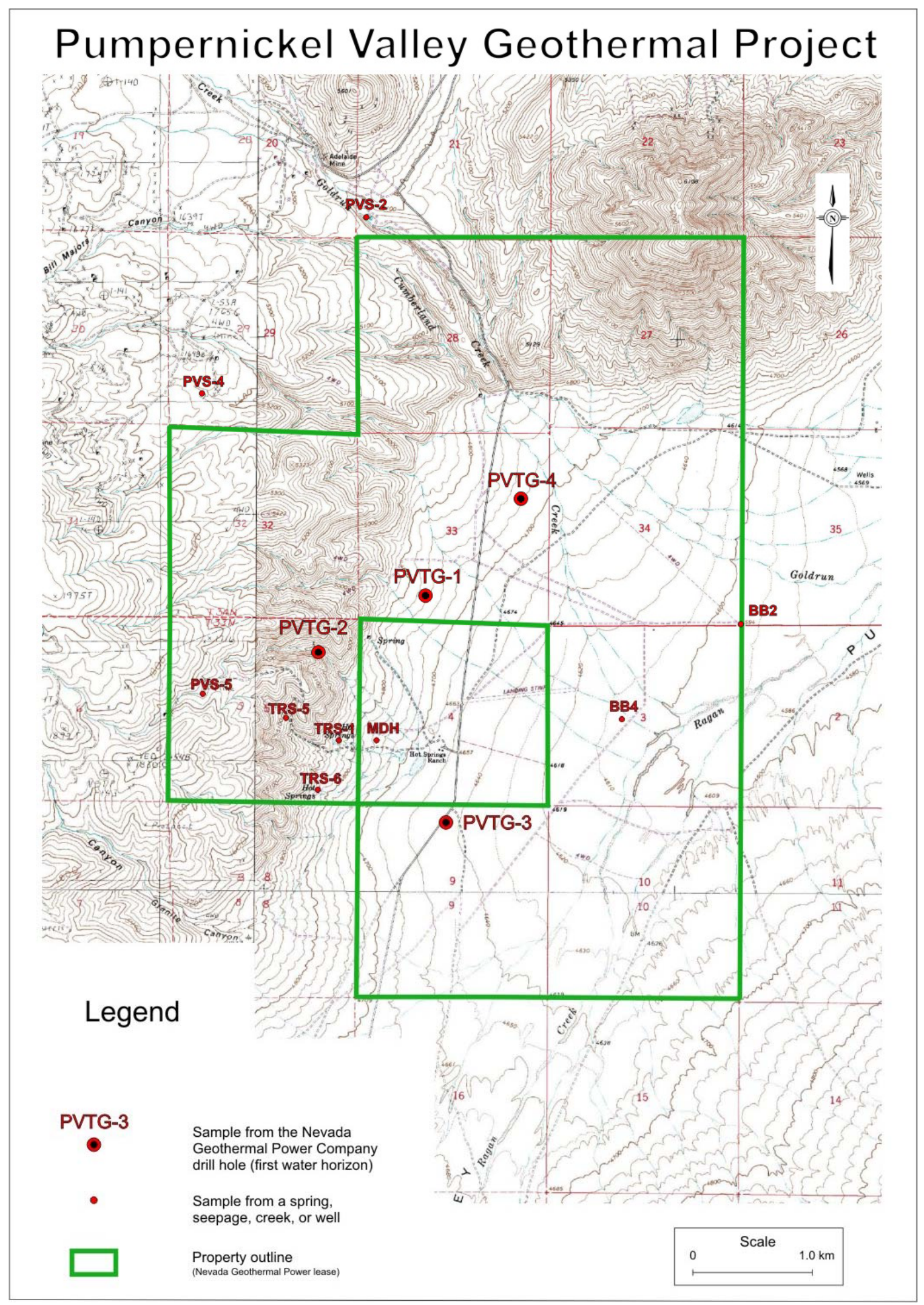

Figure 35. Location of water samples collected in the project area. 
"The higher temperature waters may be related to a limestone aquifer. The $\mathrm{Cl} / \mathrm{B} / \mathrm{Li}$ ratios are about right (see the data table in Appendix C), they are saturated with respect to calcite (see $\mathrm{Xkmc}$ ) and show an $\mathrm{Mg} / \mathrm{Ca}$ ratio slightly below that of limestone (see the Xnckm chart in Appendix C). The lower Mg would be presumably due to uptake by clays at moderate temperature.

Powell concluded that "The other waters roughly follow a gypsum dissolution trend". "They appear to mostly be in the family of the chloride-bearing, low boron, low silica (and apparently low temperature) waters and the low chloride bicarbonate rich waters that showed higher geothermometer temperatures. The low temperature chloride-bearing, low $B$ waters are probably shallow to moderate depth basin waters that don't appear to have ever been above about $60^{\circ} \mathrm{C}$."

The above conclusion has been confirmed by Jill R. Haizlip of Geologica (personal communication, 2005), who also calculated chemical geothermometers and prepared plots (Appendix C) of the results for the water samples from the thermal gradient holes in order to evaluate the presence of geothermal fluids in the samples. "The low temperature geothermometers (silica and $\mathrm{Na}-\mathrm{Mg}$ ) generally suggest temperatures in the range of $70 \pm$ $20{ }^{\circ} \mathrm{C}$ (primarily based on silica geothermometers)". "These waters can be characterized as bicarbonate, with some sodium-potassium bicarbonate and some calcium bicarbonate groundwaters. Samples from PVTG-3 and PVTG-4 have similar cation chemistry to TRS-1, the "most prospective" water identified in a previous data review (Tom Powell, see above). In addition, the PVTG-3 sample has high bicarbonate like the results from analysis of samples from the spring TRS-1”.

Haizlip stated that the "boron/chloride analytical results suggest that these waters are not related by mixing to the warmer waters (TRS-1, TRS-6 and MDH) previously identified, and the silica contents are not nearly as high. These results suggest that the sampled waters do not have a direct relationship with the warm waters previously sampled and analyzed within the valley", "however, they appear to be from a similar albeit cooler geochemical environment”.

Yet, the reasoning of Powell and Haizlip is not supported by the field observations, which suggest that there is a considerable amount of fluid mixing within the geothermal system. First, all water samples collected from the geothermal gradient wells (PVTG-1 to -4) represent the upper-most water horizons, which most certainly contain a component of the meteoric and/or ground waters. Second, cold spring and seepages occupy the same area along the fault with the hot springs (refer to the chapter on Geothermal features) and indicate that they all utilize the same fault/fracture system. Third, there is an observable case of fluid mixing in the southern set of hot springs, where water from a hot spring (TRS-6) flows within a short distance into a cold spring, from which the mixed fluid flows as a $\sim 300 \mathrm{~m}$ long creek into the valley and disappears within the valley floor. The same applies to the northern swarm of hot springs and the Magma well, from which brine actively leaks into the overburden. And fourth, the two water samples, PVS-2 and PVS-5, 
taken from the creeks located west and northwest, respectively, of the project area and flowing into the valley, already contain a geothermal fluid component.

Some rather unusual geochemical characteristics have also been noted during the previous surveys of waters in the Tipton Ranch hot springs. Wollenberg (1974; in Garside and Schilling, 1979) reported that slightly anomalous radioactivity (up to 22.5 $\mu \mathrm{R} / \mathrm{hr}$ ) is present at the springs. In addition, water from the springs and condensate from the Magma well contain elevated quantities of antimony and tungsten, both significantly higher than any other hot springs sampled in the western USA (Erdman et al., 1991).

Anomalously high concentrations of radon and mercury were found by the staff of Fairbank Engineering Ltd. in soils near the active hot springs (Hantelmann, 2005), although there seems to be a lack of obvious correlation between the anomalies and nearby geological features, like the Pumpernickel Valley fault.

\section{Setting of the Pumpernickel Valley geothermal system}

The Pumpernickel Valley project area shows a strong similarity to pull-apart structures, which form in 3-D in the stepover or in a releasing bend of the strike-slip system. The immediate zones of the Pumpernickel Valley and Edna Mountain faults display many characteristics typical of strike-slip fault systems, including some rotational deformation, superposition of structures, lens-shaped push-up structures, and local en echelon arrangement of high-angle faults.

The overall pattern of the low resistivity anomaly in the valley, represented by a complex rhomb- and/or trapezoid-shaped area bounded by two sets of approximately NNEtrending and NNW-trending faults (Figure 18), is also indicative of a releasing stepover or pull-apart basin. The western low resistivity anomaly is marked by a major NNE break in the slope associated with the Pumpernickel Valley fault, whereas at the northern end, the stepover is delimited by the approximately northwest-trending set of buried structures and the approximately west-trending Edna Mountain fault.

The two highly conductive areas, A and B-C in Figure 18 are interpreted here as subsidence centers of the pull-apart basin. The numerous en echelon linear features most likely represent extensional fans of fault-bounded blocks arranged in a stepping-down fashion. The smaller resistivity-low anomalies delineated by Shore (2005) west of the Pumpernickel Valley fault may also represent in part actively forming, smaller scale pullapart features.

Two clusters of hot springs and one fossil spring are spatially associated with sections of the Pumpernickel Valley fault (Figure 14). There is a significant amount of fluid flow from the hot springs near the Pumpernickel Valley fault directly into the valley fill. This geothermal fluid saturates the valley fill and possibly accumulates near the contact between the overburden and the basement, and emphasizes the resistivity characteristics of the fill and the structure of the basin. 
The widespread hydration and alteration around the Pumpernickel Valley fault, most likely reflect the fluid up-flow. The nearby, down dropped structural blocks may define the immediate reservoir, as suggested by the Magma hole, in which the temperature and geothermal gradient started to increase in the last 90 meters of the $919.6 \mathrm{~m}$ hole. Similar distribution of temperatures in the PVTG-3 well (Figure 34) suggests that this reservoir extends east and south of the Magma well. Clearly, the heat source responsible for the temperatures associated with this plume has not been intersected and must be at a depth greater than 920 meters (the maximum depth of the Magma well).

\section{Model for the Pumpernickel Valley geothermal field}

The overall geological and structural setting and other characteristics of the Pumpernickel Valley area are strikingly similar to parts of the nearby Dixie Valley geothermal field (Figure 36). Dixie Valley represents an active Basin and Range-type graben and lies just $80 \mathrm{~km}$ SW from the Pumpernickel Valley project area, along the strike of the main structures in west-central Nevada.

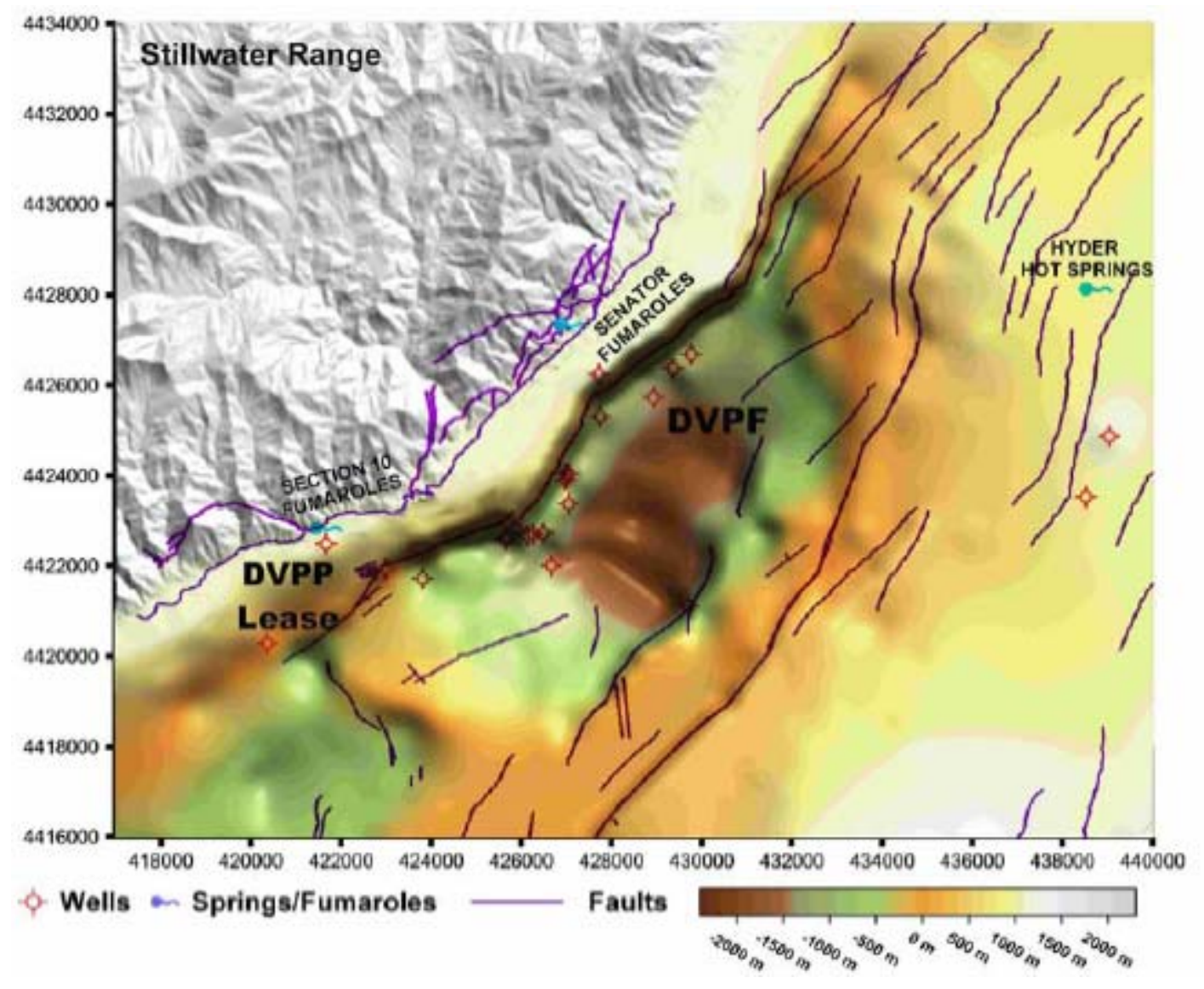

Figure 36. Dixie Valley well locations, mapped faults, and basin depth from McKenna et al. (2005).

The Dixie Valley system is a complex zone of deformation, rather than a simple planar surface (Blackwell et al., 2000; Smith et al., 2002; Johnson and Hulen, 2002; and 
McKenna et al., 2005). There are numerous Quaternary/Holocene faults in the valley whose scarps are not visible on the surface in the field, but are evidenced by the seismic reflection profiles, high-resolution aeromagnetic surveys, and detailed air photo interpretation(e.g. Blackwell, et al., 2002; Smith et al., 2002; Grauch, 2002).

The presently producing geothermal reservoir lies along a steeply dipping, multiple fault system (Blackwell et al., 2002; McKenna et al., 2005). The reservoir is made up of an unknown number of fault strands and only a few of these have been penetrated by wells. The geothermal fluid flows upward along this complex normal fault zone (Blackwell et al., 2000) and there is a significant fluid loss in the geothermal system via leakage from the piedmont faults directly into the valley fill (McKenna et al., 2005).

The reservoir, at least $5 \mathrm{~km}$ long and $2 \mathrm{~km}$ wide, has temperatures of 225 to $245^{\circ} \mathrm{C}$ at depths near $2500 \mathrm{~m}$ and over $265^{\circ} \mathrm{C}$ below 3000m (Blackwell et al., 2000; McKenna et al., 2005). The position of the highest reservoir temperatures is almost directly below the range front at a depth of about $3 \mathrm{~km}$. It has been found that the fractures feeding the geothermal field in the upper $4 \mathrm{~km}$ of the crust are steeper than $75^{\circ}$.

The Dixie Valley geothermal field has a rated output of $62 \mathrm{MW}$ and has been producing electrical power for Oxbow Geothermal Corp. since 1988 and for Caithness Operating Co. since 2000 (Blackwell et al., 2000).

\section{Conclusions}

The Pumpernickel Valley geothermal project area is located near the eastern edge of the Sonoma Range and is positioned within the structurally complex Winnemucca fold and thrust belt of north-central Nevada. A series of approximately north-northeast-striking faults related to the Basin and Range tectonics are superimposed on the earlier structures within the project area, and are responsible for the final overall geometry and distribution of the pre-existing structural features on the property.

Two of these faults, the Pumpernickel Valley fault and Edna Mountain fault, are rangebounding and display numerous characteristics, such as rotational deformation, superposition of structures, lens-shaped push-up features, local en echelon arrangement of high-angle faults, and the lithostratigraphic repetition, typical of strike-slip fault systems. These characteristics, when combined with geophysical data from Shore (2005), indicate the presence of a pull-apart basin, formed within the releasing bend of the Pumpernickel Valley - Edna Mountain fault system.

A substantial body of evidence exists, in the form of available geothermal, geological and geophysical information, to suggest that the property hosts a structurally controlled, extensive geothermal field. The most evident manifestations of the geothermal activity in the valley are two areas with hot springs, seepages, and wet ground/vegetation anomalies near the Pumpernickel Valley fault, which indicate that the fault focuses the fluid upflow. 
Magma Power Company drilled one exploration/temperature gradient borehole east of the Pumpernickel Valley fault and recorded a thermal gradient of $160^{\circ} \mathrm{C} / \mathrm{km}$. The temperature data from five mineral exploration holes to the north of the Magma well indicated geothermal gradients in a range from 66 to $249^{\circ} \mathrm{C} / \mathrm{km}$ for wells west of the fault, and $\sim 283^{\circ} \mathrm{C} / \mathrm{km}$ in a well next to the fault.

Nevada Geothermal Power Company drilled four geothermal gradient wells, PVTG-1, -2, -3 , and -4 , and all four encountered geothermal fluids. The holes provided valuable water geochemistry, supporting the geothermometry results obtained earlier from the hot springs and Magma well (Szybinski, 2005). The deepest hole, PVTG-3 never reached bedrock and the 4.5" casing was cemented back to the surface so that it could be deepened at a later date. In the other three holes, the 2" tubing has been cemented back to the surface.

The temperature data gathered from all the wells clearly indicates the presence of a major plume of thermal water centered on the Pumpernickel Valley fault, and suggests that the main plume is controlled, at least in part, by flow from this fault system. It also defines the geothermal resource with gradients $>100^{\circ} \mathrm{C} / \mathrm{km}$, which covers an area a minimum of 8 $\mathrm{km}^{2}$. Structural blocks, down dropped with respect to the Pumpernickel Valley fault, may define an immediate reservoir. The geothermal system almost certainly continues beyond the recently drilled holes and might be open to the east and south, whereas the heat source responsible for the temperatures associated with this plume has not been intersected and must be at a depth greater than 920 meters (depth of the deepest well Magma well).

The geological and structural setting and other characteristics of the Pumpernickel Valley geothermal project area are markedly similar to the portions of the nearby Dixie Valley geothermal field. These similarities include, among others, the numerous, unexposed en echelon faults and large-scale pull-apart structure, which in Dixie Valley may host part of the geothermal field.

The project area, for the majority of which Nevada Geothermal Power Company has geothermal rights, represents a geothermal site with a potential for the discovery of a relatively high temperature reservoir suitable for electric power production. Among locations not previously identified as having high geothermal potential, Pumpernickel Valley has been ranked as one of four sites with the highest potential for electrical power production in Nevada (Shevenell and Garside, 2003).

Richards and Blackwell (2002) estimated the total heat loss and the preliminary production capacity for the entire Pumpernickel Valley geothermal system to be at 35MW. A more conservative estimate, for the hot spring area only, was presented by GeothermEx Inc. (2004), which projected that power generation capacities for the Pumpernickel Valley site are $10 \mathrm{MW}-30 \mathrm{yrs}$ minimum (probablility of $>90 \%$ ), and most likely 13 MW-30yrs. 


\section{Recommendations}

Notwithstanding the results of the completed shallow thermal gradient drilling program within the project area, which intersected geothermal fluids mainly within the valley fill (with an exception of PVTG-4), there should a minimum of two deep ( $>1000 \mathrm{~m}$ ) holes drilled above the Pumpernickel Valley fault in a step-out fashion. There are field indications that this fault, dominated by a steep dip $\left(>75^{\circ}\right)$, is the major geothermal feeder. The fault might be equally steep at depth, thus it will be more effective, technically and cost wise, to use deviated drilling to increase the prospect of intersecting such a steeply dipping structure.

Borehole PVTG-3, located directly within the main low resistivity anomaly defined by Shore (2005), should be deepened and an attempt should be made to intersect the heat source associated with the geothermal plume. The line between PVTG-3 and PVTG-4, and especially in the immediate area of the low resistivity anomaly "A" (op cit), should be targeted by another deeper hole and drilled into the bedrock. The resistivity survey (op cit) indicates that possible structures in the bedrock(?), located in the vicinity of this line, may feed the geothermal system as well.

Further drilling and exploration of the Pumpernickel Valley geothermal project area should be combined with a gravity or seismic geophysical survey. The main objective of either survey will be to depict the contact between the valley fill and the basement rocks. In addition further information will be gathered on the valley faults and their relationship to the geothermal system (i.e. defining the boundaries of the geothermal reservoir). 


\section{References}

Anderson, R.E. (compiler), 2000. Fault number 1137, Edna Mountain fault, in Quaternary fault and fold database of the Unite States, ver 1.0: U.S. Geological Survey Open-File Report 03-417.

Blackwell, D.D., Golan, B., and Benoit, D., 2000. Temperatures in the Dixie Valey, Nevada Geothermal system. Geothermal Resources Council Transactions, Vol. 24, pp. 223-228.

Blackwell, D.D., Leidig, M., Smith, R.P., Johnson, S.D., and Wisian, K.W., 2002. Exploration and development techniques for Basin and Range geothermal systems: examples from Dixie Valley, Nevada. Geothermal Resources Council Transactions, Vol. 26, pp. 513-518.

Blewitt, G., Coolbaugh, M., Sawatzky, D., Holt, W., Davis, J., and Bennett, R., 2003. Targeting of potential geothermal resources in the Great Basin from regional to basin-scale relationships between geodetic strain and geological structures. Geothermal Resources Council Transactions, Vol. 27, pp. 3-7.

Boskie, R.M., 2001. Detailed structure and stratigraphy of Lower Paleozoic rocks of the Getchell Trend, Osgood Mountains, Humbolt County, Nevada. M.S. thesis, University of Nevada, Reno, 171 pages.

Erdman, J.A., Hoover, D.B., McCarthy, J.H., Jr., Ficklin, W.H., Watterson, J.R., Lovering, T.G., and Owen, R.W., 1991, Geophysical, Soil-Gas, and Geochemical Evidence of A Concealed, Mineralized Fault near Sb- and W-rich Hot Springs, Pumpernickel Valley, Nevada: U.S. Geological Survey, Open-File Report 91-0582, p. 8.

Faulds, J.E., Coolbaugh, M., Blewitt, G., and Henry, C.D., 2004. Why is Nevada in hot water? Structural controls and tectonic model of geothermal systems in the Northwestern Great Basin. Geothermal Resources Council Transactions, Vol. 28, pp.649-654.

Faulds, J., Garside, L., Johnson, G., and Hess, R., Oppliger, G., 2002 (updated 2003). Structural and geophysical analysis of the Desert Peak-Brady Geothermal Field: Identifying links between northeast-trending structures and geothermal anomalies in the Great Basin. Desert Peak Final Proposal, Nevada Bureau of Mines and Geology (NBMG) and Department of Geological Science, UNR, 16 pages.

Faulds, J.E., Garside, L.J., and Oppliger, G.L., 2003. Structural Analysis of the Desert PeakBrady Geothermal Fields, Northwestern Nevada: Implications for Understanding Linkages between Northeast-Trending Structures and Geothermal Reservoirs in the Humboldt Structural Zone. Geothermal Resources Council Annual Meeting, Morelia, Mexico.

Flynn, T. and Trexler, D.T., 1979. Use of thermophilic algae in geothermal exploration programs. Geothermal Resources Council, Transactions, Vol.3, pp.213-215.

Garside, L. J., and Schilling, J. H., 1979, Thermal waters of Nevada: Nevada Bureau of Mines and Geology Bulletin 91, 163 p.

GeothermEx, 2004. New geothermal site identification and qualification. Consultant report prepared for California Energy Commission by GeothermEx Inc. 43 pages. 
Grouch, V.J.S., 2002. High-resolution aeromagnetic survey to image shallow faults, Dixie Valley geothermal field, Nevada. U.S. Geological Survey and the Department of Energy (DOE) Openfile report 02-384, 13 pages.

Hantelmann, J., 2005. Pumpernickel Valley geothermal project: Radon soil-gas survey. Report for Nevada Geothermal Power Inc. by Fairbank Engineering Ltd. 14 pages.

Ketner, K.B., 1998. The Nature and Timing of Tectonism in the Western Facies Terrane of Nevada and California - An Outline of Evidence and Interpretations Derived From Geologic Maps of Key Areas. U.S. Geological Survey Professional Paper 1592, 19 pages.

Lerch, D.W., McWilliams, M.O., Miller, E.L., and Colgan, J.P., 2004. Structure and magmatic evolution of the northern Black Rock range, Nevada: preparation for a wide-angle refraction/reflection survey. Rocky Mountain (56 Annual) and Cordilleran (100 Annual) Joint Meeting, Paper No. 21-12.

Louie, J.N., Thelen, W., Smith, S.B., Scott, J.B., Clark, M., and Pullammanappallil, S., 2003. The Northern Walker Lane Refraction Experiment: Pn Arrivals and the Northern Sierra Nevada Root. Tectonophysics, v. 388, No.1-4, pp.253-269.

Luddington, S., McKee, E.H., Cox, D.P., Moring, B.C., and Leonard, K.R., 1996. Pre-Tertiary geology of Nevada. In Singer, D. (editor), An analysis of Nevada's metal-bearing mineral resources, Chapter 4, Nevada Bureau of Mines and Geology, OPEN-FILE REPORT 96-2, pp.1-9.

Madden-McGuire, D,J., and Marsh, S,P., 1991, Lower Paleozoic host rocks in the Getchell gold belt: Several distinct allochthons or a sequence of continuous sedimentation?: Geology, v. 19 no. 5, p. 489-492.

Mariner, R.H., J.B. Rapp, L.M., Willey, and T.S. Presser, 1974. Chemical Composition and Estimated Minimum Thermal Reservoir Temperatures of the Principal Hot Springs of Northern and Central Nevada. U.S. Geological Survey Open-File Report, 32 p.

Marsh, S.P. and Erickson, R.L., 1978. Geologic map of the Goldrun Creek quadrangle, Humboldt County, Nevada. Scale 1:24,000, GQ 1407.

McCollum, L. and McCollum, M.B. 2004. Research within the Antler and Sonoma orogens, northwestern Nevada, 1983-1993. Eastern Washington University website.

McKenna, J.R., Blackwell, D.D., Richards, M.C., and Swenson D.V., 2005. Natural state modeling, structure, preliminary temperature and chemical synthesis of the Dixie Valley, Nevada geothermal field. In Proceedings, Thirtieth Workshop on Geothermal Reservoir Engineering Stanford University, Stanford, California, 8 pages.

Rodriguez, B.D. and Williams, J.M., 2002. Resistivity structure across the Humboldt River basin, north-central Nevada. Open-file report 02-39, 23 pages.

Sadlier-Brown, T.L. 2004. A geothermal resource prospect at Hot Spring Ranch, Pumpernickel Valley, Humboldt County, Nevada. Report for Inovision Solutions Inc. by Sadlier-Brown Consulting Ltd. 24 pages. 
Shevenell, L. and Garside, L., 2003. Geochemical sampling of thermal waters in Nevada Nevada: Continued evaluation of geothermal resources for electrical power generation and direct-use applications. Nevada Bureau of Mines and Geology, 7 pages.

Shore, G.A., 2005. E-SCAN 3D resistivity mapping of the Pumpernickel Valley Grid\#1, Pumpernickel Project, Humboldt County, Nevada. Report for Nevada Geothermal Power Inc. by Premier Geophysics (US) Inc. 40 pages.

Silberling, N.J., 1975, Age relationships of the Golconda thrus fault, Sonoma Range, northcentral Nevada: Geological Society of America Special Paper 163, 28 p.

Smith, R.P., Grauch, V.J.S., and Blackwell, D.D., 2002. Preliminary results of a high-resolution aeromagnetic survey to identify buried faults at Dixie Valley, Nevada. Geothermal Resources Council Transactions, Vol. 26, pp. 543-546.

Stahl, S.D., 1987. Mesozoic structural features in Sonoma Canyon, Sonoma Range, Humboldt and Pershing counties, Nevada. Centennial Field Guide Volume 1: Cordilleran Section of the Geological Society of America: pp. 85-90.

Stahl, S.D., 1989. Recognition of Jurassic transport of rocks of the Roberts Mountains allochthon: Evidence from the Sonoma Range, north-central Nevada. Geology: Vol. 17, No. 7, pp. 645-648.

Szybinski, A., 2005. Geological setting and evaluation of the Pumpernickel Valley geothermal project area. Report for Nevada Geothermal Power Inc. and Inovision Solutions Inc., 45 p.

Trexler, D.T.,Flynn, T., Koenig, B.A., Bell, E.J., and Ghusn, G., 1982. Low- to moderatetemperature geothermal resource assessment for Nevada: area specific studies, Pumpernickel Valley, Carlin and Moana. Final report for U.S Department of Energy.

Vierra, R.K., 2005. A cultural resource inventory of four proposed temperature gradient wells and access routes in Pumpernickel Valley, Humboldt County, Nevada. Report for BLM Nr.CR2-2924(N), and addendum CR2-2924 (P) by Vierra, R.K. and Associates Inc.

Well drillers report 1975. Log No. 14542 by Edward Zajac for Division of Water Resources, State of Nevada, 1p. 
Nevada Geothermal Power Inc. and Inovision Solutions Inc

Appendix A

Statement of Qualifications 
I, Z. Adam Szybinski, do hereby certify that:

1. I am a geologist with Fairbank Engineering Ltd, with offices at suite 900, 409 Granville Street, Vancouver, BC, Canada, V6C 1T2.

2. I graduated with a M.S. degree in geology from the University of Wroclaw (Breslau), Poland, in 1975, and obtained a Ph.D. degree (1996) in Earth Sciences from Memorial University of Newfoundland, NL, Canada.

3. I have worked as geologist in mineral exploration, academia, and geological surveys since 1975, in Canada, United States, Peru, Mongolia, and Poland. My work has included examination and reporting on a broad spectrum of geological settings, together with detailed geological investigation of mineral districts, producing mines, and geothermal properties

4. I have no interest in the Pumpernickel Valley property and do not hold any interest in Nevada Geothermal Power Inc./Nevada Geothermal Power Company or in Inovision Solutions Inc.

5. I have authored this report based on the mapping, and sampling of hot springs and chips from the drill holes at the Pumpernickel Valley property, and upon the review of regional geological studies, as well as scientific papers published in recognized journals.

6. I have conducted this report under a contract with Nevada Geothermal Power Inc./ Nevada Geothermal Power Company and Mr. Brian Fairbank, P.Eng., Fairbank Engineering Ltd.

Signed and dated in Vancouver, B.C., January 09, 2006.

Z. Adam Szybinski, Ph.D. 
Nevada Geothermal Power Inc. and Inovision Solutions Inc

\title{
Appendix B
}

\author{
Chip logs
}

from the shallow thermal gradient drill holes

in the Pumpernickel Valley

geothermal project area

Drill holes:

PVTG-1

PVTG-2

PVTG-3

PVTG-4 
Nevada Geothermal Power Inc. and Inovision Solutions Inc

Drill hole:

PVTG-1

Fairbank Engineering Ltd. 


\section{FAIRBANK}

PROJECT Pumpernickel Valley HOLE NO. PVTG-1

LOCATION Pumpernickel Vly, Humboldt Co.

\section{Mud Log}
COORDINATES
459151
E, $4513580 \mathrm{~N}$
ELEV 4767 AZIMUTH $\quad$ DIP $90^{\circ}$
SECTION 33 T34N R 40E
NAD 83
LOGGED BY:
CONTRACTOR:

PAGE: $\quad 1$ OF 3

DATE: $18.8-24.8,2005$

Adam Szybinski

WDC

\begin{tabular}{|c|c|c|c|c|c|c|c|c|c|c|c|c|}
\hline \multicolumn{2}{|c|}{ DEPTH (feet) } & \multicolumn{2}{|c|}{ COLOUR } & \multicolumn{2}{|c|}{ ROUNDNESS } & \multicolumn{2}{|c|}{ GRAIN SIZE } & \multirow{2}{*}{ LITHOLOGY DESCRIPTION / COMMENTS } & \multirow{2}{*}{$\begin{array}{c}\text { Meta- } \\
\text { Seds } \%\end{array}$} & \multirow{2}{*}{$\begin{array}{c}\text { Intrusive } \\
\% \\
\end{array}$} & \multirow{2}{*}{$\begin{array}{c}\text { Volcanics } \\
\% \\
\end{array}$} & \multirow[t]{2}{*}{ Qtz \% } \\
\hline From & To & 1 & 2 & Angular & Rounded & Range & Class & & & & & \\
\hline 0 & 10 & GY & PK & A & SR & $<15 \mathrm{~mm}$ & MG & metaseds - Preble Fm.: mudstone,chert, quartzite, qtz schist, phyllite & -96 & 2 & & 2 \\
\hline 10 & 20 & GY & PK & SA & SR & $<15 \mathrm{~mm}$ & MG & metaseds - Preble Fm. & $\sim 100$ & & & \\
\hline 20 & 30 & GY & $\mathrm{BG}$ & SA & SR & $<22 \mathrm{~mm}$ & CG & metaseds - Preble Fm., adds of fels intrusives and qtz & $\sim 85$ & 5 & & 10 \\
\hline 30 & 40 & GY & $\mathrm{BG}$ & $\mathrm{SA}$ & SR & $<20 \mathrm{~mm}$ & CG & metaseds - Preble Fm., adds of fels intrusives and qtz & $\sim 80$ & 15 & & 5 \\
\hline 40 & 50 & GY & BG & SA & SR & $<25 \mathrm{~mm}$ & CG & metaseds - Preble Fm., adds of fels intrusives and qtz & $\sim 82$ & 8 & & 10 \\
\hline 50 & 60 & GY & BG & SA & SR & $<19 \mathrm{~mm}$ & CG & metaseds - Preble Fm., adds of fels intrusives and qtz & $\sim 85$ & 5 & & 10 \\
\hline 60 & 70 & GY & $\mathrm{BG}$ & SA & SR & $<21 \mathrm{~mm}$ & CG & metaseds - Preble Fm., adds of fels intrusives and qtz & $\sim 85$ & 5 & & 10 \\
\hline 70 & 80 & GY & $\mathrm{BG}$ & SA & SR & $<17 \mathrm{~mm}$ & MG & metaseds - Preble Fm., adds of fels intrusives and qtz & $\sim 90$ & 5 & & $<5$ \\
\hline 80 & 90 & GY & PK & SA & SR & $<10 \mathrm{~mm}$ & MG & metaseds - Preble Fm., adds of fels intrusives and qtz & $\sim 82$ & 15 & & $\sim 3$ \\
\hline 90 & 100 & GY & DK & SA & $\mathrm{R}$ & $<20 \mathrm{~mm}$ & CG & metaseds - Preble Fm. & $\sim 100$ & & & \\
\hline 100 & 110 & GY & PK & SA & $\mathrm{R}$ & $<9 \mathrm{~mm}$ & MG & metaseds - Preble Fm., adds of fels intrusives and qtz & $\sim 85$ & 10 & & -3 \\
\hline 110 & 120 & $\mathrm{PK}$ & GY & SA & $\mathrm{SR}$ & $<6 \mathrm{~mm}$ & FG & metaseds - Preble Fm., adds of fels intrusives and qtz & $\sim 77$ & 25 & & 8 \\
\hline 120 & 130 & GY & LT & SA & SR & $<15 \mathrm{~mm}$ & MG & metaseds - Preble Fm., adds of fels intrusives and qtz & -90 & $<5$ & & 5 \\
\hline 130 & 140 & GY & LT & SA & SR & $<10 \mathrm{~mm}$ & MG & metaseds - Preble Fm., adds of fels intrusives and qtz & $\sim 85$ & 10 & & 5 \\
\hline 140 & 150 & GY & PK & SA & SR & $<15 \mathrm{~mm}$ & MG & metaseds - Preble Fm., adds of fels intrusives and qtz & $\sim 75$ & 10 & & 15 \\
\hline 150 & 160 & GY & BG & SA & $\mathrm{R}$ & $<8 \mathrm{~mm}$ & FG & metaseds - Preble Fm., adds of fels intrusives and qtz & $\sim 90$ & 5 & & $<5$ \\
\hline 160 & 170 & GY & BG & SA & SR & $<13 \mathrm{~mm}$ & CG & metaseds - Preble Fm., adds of fels intrusives and qtz & $\sim 88$ & 10 & & -2 \\
\hline 170 & 180 & GY & BG & SA & SR & $<8 \mathrm{~mm}$ & FG & metaseds - Preble Fm., adds of fels intrusives and qtz & $\sim 85$ & 10 & & $<5$ \\
\hline 180 & 190 & GY & & & SR/R & $<15 \mathrm{~mm}$ & MG & metaseds - Preble Fm. & $\sim 100$ & & & \\
\hline 190 & 200 & GY & BG & & SR/R & $<18 \mathrm{~mm}$ & CG & metaseds - Preble Fm., adds of fels intrusives and qtz & $\sim 92$ & 5 & & $<3$ \\
\hline 200 & 210 & GY & DK & A & SR & $<20 \mathrm{~mm}$ & CG & metaseds - Preble Fm. & $\sim 100$ & & & \\
\hline 210 & 220 & GY & BG & A & SR & $<13 \mathrm{~mm}$ & MG & metaseds - Preble Fm., adds of fels intrusives and qtz & $\sim 80$ & 15 & & 5 \\
\hline 220 & 230 & GY & $\mathrm{PK}$ & A & SR & $<10 \mathrm{~mm}$ & MG & metaseds - Preble Fm., adds of fels intrusives and qtz & $\sim 85$ & 15 & & 3 \\
\hline 230 & 240 & GY & BG & SA & SR & $<11 \mathrm{~mm}$ & MG & metaseds - Preble Fm., adds of fels intrusives and qtz & $\sim 92$ & 5 & & 3 \\
\hline 240 & 250 & GY & BG & SA & $\mathrm{R}$ & $<17 \mathrm{~mm}$ & CG & metaseds - Preble Fm., adds of fels intrusives and qtz & $\sim 85$ & 10 & & 5 \\
\hline 250 & 260 & GY & BG & A & SR & $<15 \mathrm{~mm}$ & MG & metaseds - Preble Fm., adds of fels intrusives and qtz & $\sim 83$ & 12 & & 5 \\
\hline 260 & 270 & PK & GY & A & SR & $<18 \mathrm{~mm}$ & CG & metaseds - Preble Fm., adds of fels intrusives & $\sim 87$ & 13 & & \\
\hline 270 & 280 & PK & GY & SA & SR & $<19 \mathrm{~mm}$ & CG & metaseds - Preble Fm., adds of fels intrusives & $\sim 85$ & 15 & & \\
\hline 280 & 290 & PK & GY & A & SR & $<14 \mathrm{~mm}$ & MG & metaseds - Preble Fm., adds of fels intrusives and qtz & $\sim 82$ & 15 & & 3 \\
\hline 290 & 300 & GY & BG & A & SR & $<19 \mathrm{~mm}$ & CG & metaseds - Preble Fm., adds of fels intrusives and qtz & $\sim 90$ & 5 & & 5 \\
\hline 300 & 310 & GY & $\mathrm{BG}$ & SA & SR & $<17 \mathrm{~mm}$ & CG & metaseds - Preble Fm., adds of fels intrusives and qtz & $\sim 87$ & 8 & & 5 \\
\hline 310 & 320 & GY & $\mathrm{BN}$ & SA & SR & $<11 \mathrm{~mm}$ & MG & metaseds - Preble Fm., adds of fels intrusives and qtz & $\sim 85$ & 10 & & 5 \\
\hline 320 & 330 & GY & PK & A & SR & $<7 \mathrm{~mm}$ & FG & metaseds - Preble Fm., adds of fels intrusives and qtz & $\sim 60$ & 30 & & 10 \\
\hline 330 & 340 & GY & PK & A & $\mathrm{R}$ & $<15 \mathrm{~mm}$ & MG & metaseds - Preble Fm., adds of fels intrusives and qtz & $\sim 65$ & 25 & & 10 \\
\hline 340 & 350 & GY & $\mathrm{BG}$ & A & SR & $<10 \mathrm{~mm}$ & MG & metaseds - Preble Fm., adds of fels intrusives and qtz & $\sim 82$ & 10 & & 8 \\
\hline 350 & 360 & GY & BG & A & SR & $<7 \mathrm{~mm}$ & FG & metaseds - Preble Fm., adds of fels intrusives and qtz & $\sim 70$ & 15 & & 15 \\
\hline 360 & 370 & GY & $\mathrm{RD}$ & A & SR & $<8 \mathrm{~mm}$ & FG & metaseds - Preble Fm., adds of fels intrusives and qtz & $\sim 73$ & 15 & & 12 \\
\hline 370 & 380 & GY & $\mathrm{RD}$ & A & SR & $<8 \mathrm{~mm}$ & FG & metaseds - Preble Fm., adds of fels intrusives and qtz & $\sim 74$ & 16 & & 8 \\
\hline
\end{tabular}




\section{FAIRBANK}

PROJECT Pumpernickel Valley

HOLE NO PVTG-1

LOCATION Pumpernickel Vly, Humboldt Co.

\section{Mud Log}

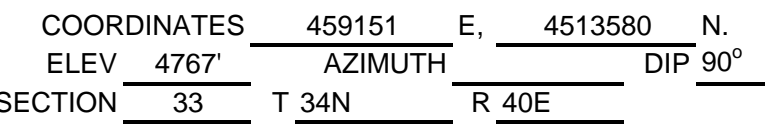
NAD
LGGED BY:
CONTRACTOR:

PAGE:

2 OF 3

DATE: $18.8-24.8,2005$ Adam Szybinski WDC

\begin{tabular}{|c|c|c|c|c|c|c|c|c|c|c|c|c|}
\hline \multicolumn{2}{|c|}{ DEPTH (feet) } & \multicolumn{2}{|c|}{ COLOUR } & \multicolumn{2}{|c|}{ ROUNDNESS } & \multicolumn{2}{|c|}{ GRAIN SIZE } & \multirow{2}{*}{ LITHOLOGY DESCRIPTION / COMMENTS } & \multirow{2}{*}{$\begin{array}{l}\text { Meta- } \\
\text { Seds \% }\end{array}$} & \multirow{2}{*}{$\begin{array}{c}\text { Intrusive } \\
\%\end{array}$} & \multirow{2}{*}{$\begin{array}{c}\text { Volcanics } \\
\%\end{array}$} & \multirow[t]{2}{*}{ Qtz \% } \\
\hline From & To & 1 & 2 & Angular & Rounded & Range & Class & & & & & \\
\hline 380 & 390 & GY & $\mathrm{RD}$ & A & SR & $<8 \mathrm{~mm}$ & FG & metaseds - Preble Fm., adds of fels intrusives and qtz & $\sim 82$ & 10 & & 8 \\
\hline 390 & 400 & GY & BG & A & SR & $<10 \mathrm{~mm}$ & MG & metaseds - Preble Fm., adds of fels intrusives and qtz & $\sim 80$ & 15 & & 5 \\
\hline 400 & 410 & GY & BG & $\mathrm{SA}$ & $\mathrm{SR}$ & $<8 \mathrm{~mm}$ & CG & metaseds - Preble Fm., adds of fels intrusives and qtz & $\sim 70$ & 20 & & 10 \\
\hline 410 & 420 & GY & $\mathrm{RD}$ & SA & SR & $<15 \mathrm{~mm}$ & CG & metaseds - Preble Fm., adds of fels intrusives and qtz & -82 & 10 & & 8 \\
\hline 420 & 430 & GY & $\mathrm{RD}$ & SA & SR & $<12 \mathrm{~mm}$ & MG & metaseds - Preble Fm., adds of fels intrusives and qtz & $>90$ & $<5$ & & $<5$ \\
\hline 430 & 440 & GY & $\mathrm{PK}$ & $\mathrm{A}$ & SR & $<12 \mathrm{~mm}$ & MG & metaseds - Preble Fm., adds of fels intrusives and qtz & $\sim 78$ & 15 & & 7 \\
\hline 440 & 450 & GY & $\mathrm{PK}$ & $\mathrm{SA}$ & SR & $<10 \mathrm{~mm}$ & MG & metaseds - Preble Fm., adds of fels intrusives and qtz & $>90$ & 5 & & $<5$ \\
\hline 450 & 460 & $\overline{G Y}$ & $\mathrm{BN}$ & A & $\mathrm{R}$ & $<9 \mathrm{~mm}$ & MG & metaseds - Preble Fm., adds of fels intrusives and qtz & $\sim 85$ & 7 & & 8 \\
\hline 460 & 470 & GY & $\mathrm{PK}$ & A & SR & $<6 \mathrm{~mm}$ & FG & metaseds - Preble Fm., adds of fels intrusives and qtz & $\sim 78$ & 12 & & 10 \\
\hline 470 & 480 & GY & BG & SA & SR & $<10 \mathrm{~mm}$ & MG & metaseds - Preble Fm., adds of fels intrusives and qtz & $\sim 88$ & 10 & & 8 \\
\hline 480 & 490 & GY & BG & SA & $\mathrm{R}$ & $<9 \mathrm{~mm}$ & MG & metaseds - Preble Fm., adds of fels intrusives and qtz & $\sim 87$ & 5 & & 8 \\
\hline 490 & 500 & PK & BG & A & SR & $<13 \mathrm{~mm}$ & MG & metaseds - Preble Fm., adds of fels intrusives and qtz & $\sim 80$ & 12 & & 8 \\
\hline 500 & 510 & GY & BG & SA & SR & $<8 \mathrm{~mm}$ & FG & metaseds - Preble Fm., adds of fels intrusives and qtz & $\sim 79$ & 12 & & 9 \\
\hline 510 & 520 & GY & BG & SA & $\mathrm{SR}$ & $<7 \mathrm{~mm}$ & FG & metaseds - Preble Fm., adds of fels intrusives, volcs, qtz & $\sim 85$ & $<5$ & 8 & 10 \\
\hline 520 & 530 & $\mathrm{PK}$ & GY & $\mathrm{A} / \mathrm{SA}$ & & $<13 \mathrm{~mm}$ & MG & Tertiary volcs, metaseds of Preble Fm., felsic intrusives, qtz & $\sim 38$ & 8 & $\sim 50$ & 4 \\
\hline 530 & 540 & $\mathrm{PK}$ & GY & A/SA & & $<11 \mathrm{~mm}$ & MG & metaseds of Preble Fm., adds of Tertiary volcs, fels intrusives, qtz & $\sim 65$ & 5 & -25 & 5 \\
\hline 540 & 550 & & & & & & & no sample & & & & \\
\hline 550 & 560 & GY & BG & A/SA & & $<12 \mathrm{~mm}$ & MG & Tertiary volcs, adds of metaseds, fels intrusives, qtz & 17 & 3 & $\sim 80$ & \\
\hline 560 & 570 & GY & BG & A/SA & & $<12 \mathrm{~mm}$ & MG & Tertiary volcs, adds of metaseds, fels intrusives, qtz & $<3$ & 2 & $>95$ & \\
\hline 570 & 580 & GY & BG & A & $\mathrm{SR}$ & $<11 \mathrm{~mm}$ & MG & metaseds - Preble Fm., adds of fels intrusives, volcs, qtz & $\sim 85$ & 5 & 5 & 5 \\
\hline 580 & 590 & GY & BG & A/SA & & $<14 \mathrm{~mm}$ & MG & metaseds of Preble Fm., adds of Tertiary volcs, fels intrusives, qtz & $\sim 62$ & 5 & 25 & 8 \\
\hline 590 & 600 & GY & BG & $\mathrm{A} / \mathrm{SA}$ & & $<11 \mathrm{~mm}$ & MG & metaseds of Preble Fm., adds of Tertiary volcs, fels intrusives, qtz & $>75$ & $<5$ & 15 & $<5$ \\
\hline 600 & 610 & & & & & & & no sample & & & & \\
\hline 610 & 620 & GY & $\mathrm{PK}$ & $\mathrm{A} / \mathrm{SA}$ & & $<7 \mathrm{~mm}$ & FG & metaseds - Preble Fm., adds of qtz & $\sim 95$ & & & 5 \\
\hline 620 & 630 & GY & $\mathrm{PK}$ & A & SR & $<8 \mathrm{~mm}$ & FG & metaseds - Preble Fm., adds of fels intrusives, volcs, qtz & $\sim 92$ & & 8 & \\
\hline 630 & 640 & GY & $\mathrm{PK}$ & A & SR & $<13 \mathrm{~mm}$ & MG & metaseds - Preble Fm., adds of fels intrusives, volcs, qtz & $\sim 92$ & & 5 & 3 \\
\hline 640 & 650 & GY & $\mathrm{PK}$ & $\bar{A}$ & SR & $<6 \mathrm{~mm}$ & FG & metaseds - Preble Fm., adds of fels intrusives, volcs, qtz & $\sim 90$ & 7 & 3 & \\
\hline 650 & 660 & GY & $\mathrm{OL}$ & A & SR & $<10 \mathrm{~mm}$ & MG & metaseds - Preble Fm., adds of fels intrusives & $\sim 97$ & 3 & & \\
\hline 660 & 670 & GY & BG & A & SR & $<8 \mathrm{~mm}$ & FG & metaseds - Preble Fm., adds of fels intrusives & $>97$ & $<3$ & & \\
\hline 670 & 680 & GY & BG & $\mathrm{A}$ & SR & $<8 \mathrm{~mm}$ & FG & metaseds - Preble Fm. & $\sim 100$ & & & \\
\hline 680 & 690 & GY & BG & SA & SR & $<7 \mathrm{~mm}$ & CG & metaseds - Preble Fm., adds of fels intrusives & $\sim 95$ & 5 & & \\
\hline 690 & 700 & GY & BG & A & SR & $<8 \mathrm{~mm}$ & FG & metaseds - Preble Fm., minor volcs & $\sim 99$ & & 1 & \\
\hline 700 & 710 & GY & BG & A & SR & $<8 \mathrm{~mm}$ & FG & metaseds - Preble Fm., minor volcs & $\sim 99$ & & 1 & \\
\hline 710 & 720 & & & & & & & poor sample & & & & \\
\hline 720 & 730 & GY & BG & $\bar{A}$ & SR & $<6 \mathrm{~mm}$ & FG & metaseds - Preble Fm. & $\sim 100$ & & & \\
\hline 730 & 740 & GY & BG & SA & $\mathrm{R}$ & $<7 \mathrm{~mm}$ & FG & metaseds - Preble Fm. & $\sim 100$ & & & \\
\hline 740 & 750 & GY & BG & A & SR & $<7 \mathrm{~mm}$ & FG & metaseds - Preble Fm., minor volcs & $\sim 98$ & & $1-2$ & \\
\hline 750 & 760 & GY & BG & $\mathrm{A}$ & SR & $<8 \mathrm{~mm}$ & FG & metaseds - Preble Fm. & $\sim 100$ & & & \\
\hline
\end{tabular}




\section{FAIRBANK}

PROJECT Pumpernickel Valley

HOLE NO.

LOCATION Pumpernickel Vly, Humboldt Co.

\section{Mud Log}

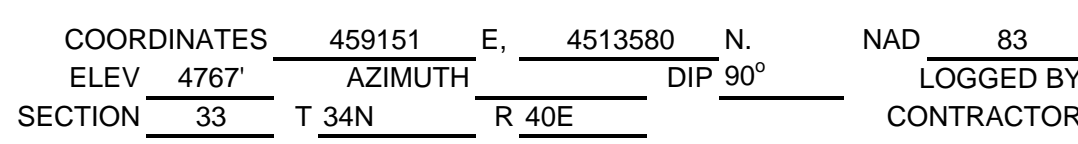

PAGE:

$3 \mathrm{OF} 3$

DATE: 18.8-24.8, 2005

Adam Szybinski WDC

\begin{tabular}{|c|c|c|c|c|c|c|c|c|c|c|c|c|}
\hline \multicolumn{2}{|c|}{ DEPTH (feet) } & \multicolumn{2}{|c|}{ COLOUR } & \multicolumn{2}{|c|}{ ROUNDNESS } & \multicolumn{2}{|c|}{ GRAIN SIZE } & \multirow{2}{*}{ LITHOLOGY DESCRIPTION / COMMENTS } & \multirow{2}{*}{$\begin{array}{l}\text { Meta- } \\
\text { Seds \% }\end{array}$} & \multirow{2}{*}{$\begin{array}{c}\text { Intrusive } \\
\%\end{array}$} & \multirow{2}{*}{$\begin{array}{c}\text { Volcanics } \\
\%\end{array}$} & \multirow[t]{2}{*}{ Qtz \% } \\
\hline From & To & 1 & 2 & Angular & Rounded & Range & Class & & & & & \\
\hline 760 & 770 & GY & BG & $A$ & $R$ & $<4.5 \mathrm{~mm}$ & VFG & metaseds - Preble Fm. & $\sim 100$ & & & \\
\hline 770 & 780 & GY & BG & $\mathrm{SA}$ & $\mathrm{R}$ & $<7 \mathrm{~mm}$ & $F G$ & metaseds - Preble Fm. & $\sim 100$ & & & \\
\hline 780 & 790 & GY & BG & A & SR & $<9 \mathrm{~mm}$ & MG & metaseds - Preble Fm. & $\sim 100$ & & & \\
\hline 790 & 800 & GY & $\mathrm{RD}$ & A & SR & $<7 \mathrm{~mm}$ & FG & metaseds - Preble Fm. & $\sim 100$ & & & \\
\hline 800 & 810 & GY & $\mathrm{PK}$ & $\overline{S A}$ & SR & $<9 \mathrm{~mm}$ & MG & Tertiary ash-flow tuffs, metaseds of Preble Fm., adds of qtz & $\sim 40$ & & $\sim 40$ & $\sim 20$ \\
\hline 810 & 820 & $\mathrm{PK}$ & & $\bar{A}$ & SR & $<10 \mathrm{~mm}$ & chips & Tertiary ash-flow tuffs & & & 100 & \\
\hline 820 & 830 & PK & & A & SR & $<12 \mathrm{~mm}$ & MG & Tertiary ash-flow tuffs, adds of metaseds of Preble Fm. & 20 & & -80 & \\
\hline 830 & 840 & $\mathrm{PK}$ & & A & SR & $<11 \mathrm{~mm}$ & chips & Tertiary ash-flow tuffs, adds of metaseds of Preble Fm. & 5 & & -95 & \\
\hline 840 & 850 & $\mathrm{PK}$ & $\mathrm{BN}$ & A & $\overline{\mathrm{SR}}$ & $<16 \mathrm{~mm}$ & MG & Tertiary ash-flow tuffs, adds of metaseds of Preble Fm. & 10 & & $\sim 90$ & \\
\hline 850 & 860 & $\mathrm{PK}$ & $\mathrm{BN}$ & A/SA & & $<10 \mathrm{~mm}$ & chips & Tertiary ash-flow tuffs & & & 100 & \\
\hline 860 & 870 & $\mathrm{PK}$ & $\mathrm{BN}$ & $\bar{A} / \mathrm{SA}$ & & $<6 \mathrm{~mm}$ & chips & Tertiary ash-flow tuffs, adds of metaseds of Preble Fm. & 5 & & -95 & \\
\hline 870 & 880 & $\mathrm{PK}$ & $\mathrm{BN}$ & VA/SA & & $<14 \mathrm{~mm}$ & chips & Tertiary ash-flow tuffs & & & 100 & \\
\hline 880 & 890 & $\mathrm{PK}$ & $\mathrm{BN}$ & VA/SA & & $<10 \mathrm{~mm}$ & chips & Tertiary ash-flow tuffs & & & 100 & \\
\hline 890 & 900 & $\mathrm{PK}$ & $\mathrm{BN}$ & VA/SA & & $<9 \mathrm{~mm}$ & chips & Tertiary ash-flow tuffs, adds of metaseds of Preble Fm. & 5 & & -95 & \\
\hline 900 & 910 & $\mathrm{PK}$ & $\mathrm{BN}$ & $\mathrm{A} / \mathrm{SA}$ & & $<5 \mathrm{~mm}$ & chips & Tertiary ash-flow tuffs & & & 100 & \\
\hline 910 & 920 & $\mathrm{PK}$ & BG & $\mathrm{A} / \mathrm{SA}$ & & $<6 \mathrm{~mm}$ & chips & Tertiary ash-flow tuffs & & & 100 & \\
\hline 920 & 930 & $\mathrm{PK}$ & BG & VA/SA & & $<16 \mathrm{~mm}$ & chips & Tertiary ash-flow tuffs, adds of metaseds of Preble Fm. & 5 & & -95 & \\
\hline 930 & 940 & $\mathrm{PK}$ & BG & A & SR & $<12 \mathrm{~mm}$ & MG & Tertiary ash-flow tuffs, adds of metaseds of Preble Fm., qtz & 35 & & -50 & 15 \\
\hline 940 & 950 & PK & $\mathrm{BN}$ & A & SR & $<8 \mathrm{~mm}$ & MG & Tertiary ash-flow tuffs and metaseds of Preble Fm. & -50 & & -50 & \\
\hline 950 & 960 & $\mathrm{PK}$ & GY & $\overline{V A}$ & SR & $<6 \mathrm{~mm}$ & FG & Tertiary ash-flow tuffs and metaseds of Preble Fm. & $\sim 40$ & & $\sim 60$ & \\
\hline 960 & 970 & $\mathrm{PK}$ & GY & A & SR & $<9 \mathrm{~mm}$ & MG & Tertiary ash-flow tuffs and metaseds of Preble Fm. & -40 & & $\sim 60$ & \\
\hline 970 & 980 & PK & GY & $\overline{\mathrm{VA}}$ & SR & $<8 \mathrm{~mm}$ & FG & Tertiary ash-flow tuffs and metaseds of Preble Fm. & $\sim 50$ & & $\sim 50$ & \\
\hline 980 & 990 & $\mathrm{PK}$ & GY & A & SR & $<8 \mathrm{~mm}$ & $\mathrm{fG}$ & metaseds of Preble Fm. and Tertiary ash-flow tuffs & $\sim 70$ & & 30 & \\
\hline 990 & 1000 & PK & GY & A & SR & $<8 \mathrm{~mm}$ & FG & metaseds of Preble Fm., adds of Tertiary ash-flow tuffs & $\sim 85$ & & 15 & \\
\hline Abbrev & Color & & & Abbrev & Round & & & Abbreviation - rock/mineral type & & & & \\
\hline $\mathrm{BG}$ & Beige & & & $\overline{\mathrm{VA}}$ & very & angular & & metaseds = metasediments & & & & \\
\hline $\mathrm{BL}$ & Blue & & & A & angular & & & qtz = quartz & & & & \\
\hline $\mathrm{BN}$ & Brown & & & $\overline{S A}$ & sub- & angular & & qtz-fds-bio = quartz-feldspar-biotite & & & & \\
\hline $\mathrm{CH}$ & Charcoa & & & SR & sub- & rounded & & qtzites = quartzites & & & & \\
\hline $\mathrm{GN}$ & Green & & & $\bar{R}$ & rounded & & & fel $=$ felsic & & & & \\
\hline GY & Gray & & & & & & & volcs $=$ volcanics & & & & \\
\hline OL & Olive & & & & & & & sst = sandstones & & & & \\
\hline PK & Pink & & & & & & & $\mathrm{ox}=$ Fe oxidized & & & & \\
\hline $\mathrm{PE}$ & Purple & & & & & & & adds $=$ additions & & & & \\
\hline RD & Red & & & & & & & & & & & \\
\hline RY & Rusty & & & DK & Dark & & & & & & & \\
\hline $\mathrm{YL}$ & Yellow & & & LT & Light & & & & & & & \\
\hline
\end{tabular}


Nevada Geothermal Power Inc. and Inovision Solutions Inc

Drill hole:

PVTG-2

Fairbank Engineering Ltd. 


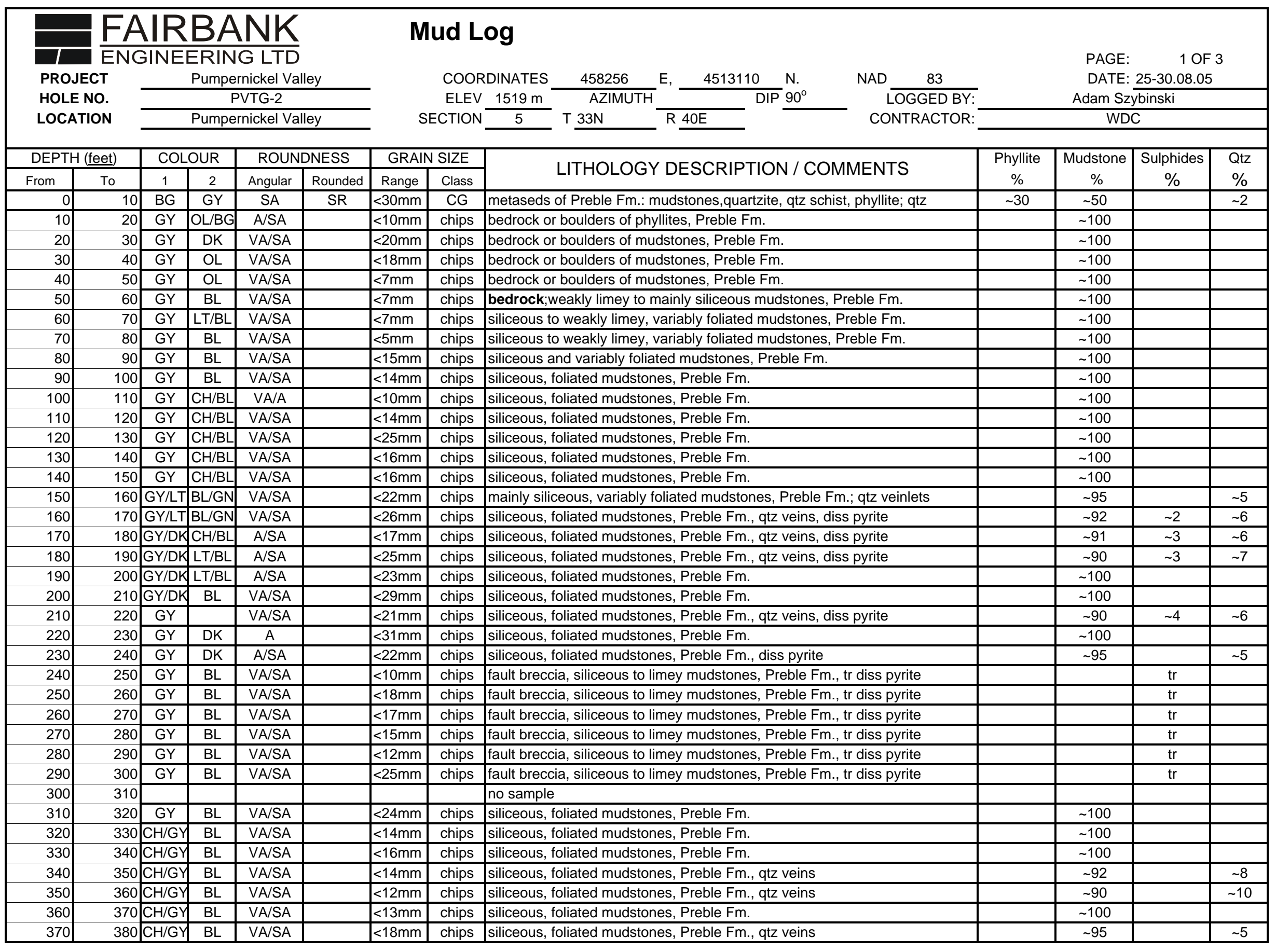




\section{FAIRBANK}

HOLE NO PVTG-2

LOCATION Pumpernickel Valley

\section{Mud Log}

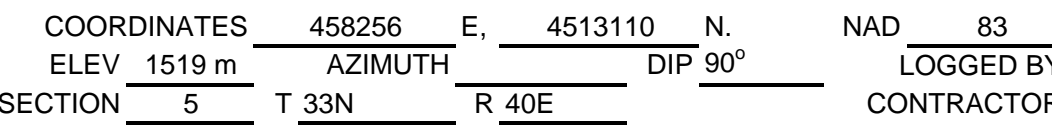

PAGE:

2 OF 3

DATE: 25-30.08.05 Adam Szybinski WDC

\begin{tabular}{|c|c|c|c|c|c|c|c|c|c|c|c|c|}
\hline \multicolumn{2}{|c|}{ DEPTH (feet) } & \multicolumn{2}{|c|}{ COLOUR } & \multicolumn{2}{|c|}{ ROUNDNESS } & \multicolumn{2}{|c|}{ GRAIN SIZE } & \multirow{2}{*}{ LITHOLOGY DESCRIPTION / COMMENTS } & \multirow{2}{*}{$\begin{array}{c}\text { Phyllite } \\
\%\end{array}$} & \multirow{2}{*}{$\begin{array}{c}\text { Mudstone } \\
\%\end{array}$} & \multirow{2}{*}{\begin{tabular}{|c|} 
Sulphides \\
$\%$
\end{tabular}} & \multirow{2}{*}{$\begin{array}{l}\text { Qtz } \\
\%\end{array}$} \\
\hline From & To & 1 & 2 & Angular & Rounded & Range & Class & & & & & \\
\hline 380 & 390 & GY/CH & $\mathrm{BL}$ & VA/SA & & $<18 \mathrm{~mm}$ & chips & siliceous, foliated mudstones, Preble Fm., qtz veins, tr diss pyrite & & 298 & $\operatorname{tr}$ & $<2$ \\
\hline 390 & 400 & $\mathrm{GY} / \mathrm{CH}$ & $\mathrm{BL}$ & VA/SA & & $<13 \mathrm{~mm}$ & chips & siliceous, foliated mudstones, Preble Fm., qtz veins, tr diss pyrite & & $\sim 98$ & $\operatorname{tr}$ & $<2$ \\
\hline 400 & 410 & $\mathrm{GY} / \mathrm{CH}$ & $\mathrm{BL}$ & VA/SA & & $<10 \mathrm{~mm}$ & chips & siliceous, foliated mudstones, Preble Fm., qtz veins, tr diss pyrite & & $\sim 98$ & $\operatorname{tr}$ & $<2$ \\
\hline 410 & 420 & GY/CH & $\mathrm{BL}$ & VA/SA & & $<12 \mathrm{~mm}$ & chips & siliceous, foliated mudstones, Preble Fm., qtz veins, tr diss pyrite & & $\sim 98$ & tr & $<2$ \\
\hline 420 & 430 & $\mathrm{GY} / \mathrm{CH}$ & $\mathrm{BL}$ & VA/SA & & $<12 \mathrm{~mm}$ & chips & siliceous, foliated mudstones, Preble Fm., qtz veins, tr diss pyrite & & $\sim 99$ & $\operatorname{tr}$ & $\sim 1$ \\
\hline 430 & 440 & $\mathrm{GY} / \mathrm{CH}$ & $\mathrm{BL}$ & VA/SA & & $<9 \mathrm{~mm}$ & chips & siliceous, foliated mudstones, Preble Fm., qtz veins, tr diss pyrite & & $\sim 99$ & $\operatorname{tr}$ & $\sim 1$ \\
\hline 440 & 450 & $\mathrm{GY} / \mathrm{CH}$ & $\mathrm{BL}$ & VA/SA & & $<11 \mathrm{~mm}$ & chips & siliceous, foliated mudstones, Preble Fm., qtz veins, tr diss pyrite & & $\sim 99$ & $\operatorname{tr}$ & -1 \\
\hline 450 & 460 & $\mathrm{GY} / \mathrm{CH}$ & $\mathrm{BL}$ & VA/SA & & $<10 \mathrm{~mm}$ & chips & siliceous, foliated mudstones, Preble Fm., qtz veins, tr diss pyrite & & $\sim 99$ & $\operatorname{tr}$ & $\sim 1$ \\
\hline 460 & 470 & $\mathrm{GY} / \mathrm{CH}$ & $\mathrm{BL}$ & VA/SA & & $<10 \mathrm{~mm}$ & chips & siliceous, foliated mudstones, Preble Fm., qtz veins, tr diss pyrite & & $\sim 99$ & $\operatorname{tr}$ & $\sim 1$ \\
\hline 470 & 480 & $\mathrm{GY} / \mathrm{CH}$ & $\mathrm{BL}$ & VA/SA & & $<15 \mathrm{~mm}$ & chips & siliceous, foliated mudstones, Preble Fm., qtz veins, diss pyrite & & $\sim 99$ & $\operatorname{tr}$ & $\sim 1$ \\
\hline 480 & 490 & $\mathrm{GY} / \mathrm{CH}$ & $\mathrm{BL}$ & VA/SA & & $<8 \mathrm{~mm}$ & chips & siliceous, foliated mudstones, Preble Fm., qtz veins, tr diss pyrite & & $\sim 99$ & $\operatorname{tr}$ & -1 \\
\hline 490 & 500 & $\mathrm{GY} / \mathrm{CH}$ & $\mathrm{BL}$ & VA/SA & & $<17 \mathrm{~mm}$ & chips & siliceous, foliated mudstones, Preble Fm., qtz veins, tr diss pyrite & & $\sim 99$ & $\operatorname{tr}$ & $\sim 1$ \\
\hline 500 & 510 & $\mathrm{GY} / \mathrm{CH}$ & $\mathrm{BL}$ & VA/SA & & $<10 \mathrm{~mm}$ & chips & siliceous, foliated mudstones, Preble Fm., qtz veins & & $\sim 95$ & & $\sim 5$ \\
\hline 510 & 520 & $\mathrm{GY} / \mathrm{CH}$ & $\mathrm{BL}$ & VA/SA & & $<12 \mathrm{~mm}$ & chips & siliceous, foliated mudstones, Preble Fm., qtz veins & & $\sim 95$ & & $\sim 5$ \\
\hline 520 & 530 & $\mathrm{GY} / \mathrm{CH}$ & $\mathrm{BL}$ & VA/SA & & $<12 \mathrm{~mm}$ & chips & siliceous, foliated mudstones, Preble Fm., qtz veins & & -95 & & $\sim 5$ \\
\hline 530 & 540 & $\mathrm{GY} / \mathrm{CH}$ & $\mathrm{BL}$ & VA/SA & & $<9 \mathrm{~mm}$ & chips & siliceous, foliated mudstones, Preble Fm. & & $\sim 100$ & & \\
\hline 540 & 550 & $\mathrm{GY} / \mathrm{CH}$ & $\mathrm{BL}$ & VA/SA & & $<9 \mathrm{~mm}$ & chips & siliceous, foliated mudstones, Preble Fm., qtz veins & & $\sim 98$ & & $\sim 2$ \\
\hline 550 & 560 & $\mathrm{GY} / \mathrm{CH}$ & $\mathrm{BL}$ & VA/SA & & $<16 \mathrm{~mm}$ & chips & siliceous, foliated mudstones, Preble Fm., qtz veins & & $\sim 95$ & & $\sim 5$ \\
\hline 560 & 570 & $\mathrm{GY} / \mathrm{CH}$ & $\mathrm{BL}$ & VA/SA & & $<15 \mathrm{~mm}$ & chips & siliceous, foliated mudstones, Preble Fm., qtz veins & & $\sim 95$ & & $\sim 5$ \\
\hline 570 & 580 & $\mathrm{GY} / \mathrm{CH}$ & $\mathrm{BL}$ & VA/SA & & $<15 \mathrm{~mm}$ & chips & mainly siliceous, somewhat phyllitic mudstones of the Preble Fm., qtz veinlet & & $\sim 95$ & $\operatorname{tr}$ & $\sim 5$ \\
\hline 580 & 590 & $\mathrm{GY} / \mathrm{CH}$ & $\mathrm{BL}$ & VA/SA & & $<10 \mathrm{~mm}$ & chips & siliceous, foliated mudstones, Preble Fm., qtz veins & & $\sim 98$ & & $\sim 2$ \\
\hline 590 & 600 & $\mathrm{GY} / \mathrm{CH}$ & $\mathrm{BL}$ & VA/SA & & $<10 \mathrm{~mm}$ & chips & mainly siliceous, somewhat phyllitic mudstones of the Preble Fm. & & $\sim 100$ & & \\
\hline 600 & 610 & GY & DK & VA/SA & & $<20 \mathrm{~mm}$ & chips & mainly siliceous, somewhat phyllitic mudstones of the Preble Fm. & & $\sim 100$ & & \\
\hline 610 & 620 & $\mathrm{GY} / \mathrm{CH}$ & $\mathrm{BL}$ & VA/SA & & $<10 \mathrm{~mm}$ & chips & siliceous, foliated mudstones, Preble Fm., qtz veins & & $\sim 99$ & & -1 \\
\hline 620 & 630 & $\mathrm{GY} / \mathrm{CH}$ & $\mathrm{BL}$ & VA/SA & & $<9 \mathrm{~mm}$ & chips & siliceous, foliated mudstones, Preble Fm., qtz veins, tr diss pyrite & & $\sim 99$ & $\operatorname{tr}$ & $\sim 1$ \\
\hline 630 & 640 & $\mathrm{GY} / \mathrm{CH}$ & $\mathrm{BL}$ & VA/SA & & $<8 \mathrm{~mm}$ & chips & siliceous, foliated mudstones, Preble Fm., tr diss pyrite & & $\sim 100$ & $\operatorname{tr}$ & \\
\hline 640 & 650 & $\mathrm{GY} / \mathrm{CH}$ & $\mathrm{BL}$ & VA/SA & & $<19 \mathrm{~mm}$ & chips & siliceous to weakly limey mudstones, Preble Fm., qtz veins, tr pyrite & & $\sim 98$ & $\operatorname{tr}$ & $<2$ \\
\hline 650 & 660 & GY/CH & $\mathrm{BL}$ & VA/SA & & $<11 \mathrm{~mm}$ & chips & siliceous to weakly limey mudstones, Preble Fm., qtz veins, tr pyrite & & $\sim 98$ & $\operatorname{tr}$ & $<2$ \\
\hline 660 & 670 & $\mathrm{GY} / \mathrm{CH}$ & $\mathrm{BL}$ & VA/SA & & $<10 \mathrm{~mm}$ & chips & siliceous to weakly limey mudstones, Preble Fm., qtz veins, tr pyrite & & $\sim 98$ & $\operatorname{tr}$ & $<2$ \\
\hline 670 & 680 & GY & & VA/SA & & $<11 \mathrm{~mm}$ & chips & siliceous to weakly limey mudstones, Preble Fm., qtz veins, tr pyrite & & $\sim 98$ & $\operatorname{tr}$ & $\sim 2$ \\
\hline 680 & 690 & GY & & VA/SA & & $<11 \mathrm{~mm}$ & chips & siliceous to weakly limey mudstones, Preble Fm., qtz veins, tr pyrite & & $\sim 98$ & $\operatorname{tr}$ & $\sim 2$ \\
\hline 690 & 700 & $\mathrm{GY} / \mathrm{CH}$ & DK & VA/SA & & $<5 \mathrm{~mm}$ & chips & siliceous to weakly limey mudstones, Preble Fm., qtz veins, tr pyrite & & $\sim 98$ & $\operatorname{tr}$ & $\sim 2$ \\
\hline 700 & 710 & GY & $\mathrm{LT}$ & VA/SA & & $<8 \mathrm{~mm}$ & chips & siliceous to weakly limey mudstones, Preble Fm., qtz veins & & $\sim 90$ & & $\sim 10$ \\
\hline 710 & 720 & GY & $\mathrm{CH}$ & VA/SA & & $<7 \mathrm{~mm}$ & chips & siliceous to weakly limey mudstones, Preble Fm., qtz veins & & $\sim 88$ & & $\sim 12$ \\
\hline 720 & 730 & GY & $\mathrm{CH}$ & VA/SA & & $<12 \mathrm{~mm}$ & chips & siliceous to weakly limey mudstones, Preble Fm., qtz veins, tr pyrite & & $\sim 85$ & $\operatorname{tr}$ & $\sim 15$ \\
\hline 730 & 740 & GY & $\mathrm{LT}$ & VA/SA & & $<7 \mathrm{~mm}$ & chips & siliceous to weakly limey mudstones, Preble Fm., qtz veins & & $\sim 80$ & & $\sim 20$ \\
\hline 740 & 750 & GY & $\mathrm{CH}$ & VA/SA & & $<20 \mathrm{~mm}$ & chips & siliceous to weakly limey mudstones, Preble Fm., qtz veins, tr pyrite & & $\sim 85$ & $\operatorname{tr}$ & $\sim 15$ \\
\hline 750 & 760 & $\mathrm{LT} / \mathrm{CH}$ & $\mathrm{BL}$ & VA/SA & & $<12 \mathrm{~mm}$ & chips & siliceous to weakly limey mudstones, Preble Fm., qtz veins & & $\sim 95$ & & $\sim 5$ \\
\hline
\end{tabular}




\section{EFAIRBANK}

PROJECT

HOLE NO.

Pumpernickel Valley

LOCATION

PVTG-2

Pumpernickel Valley

\begin{tabular}{|c|c|c|c|c|c|}
\hline \multicolumn{2}{|c|}{ DEPTH (feet) } & \multicolumn{2}{|c|}{ COLOUR } & \multicolumn{2}{|c|}{ ROUNDNESS } \\
\hline From & To & 1 & 2 & Angular & Rounded \\
\hline 760 & 770 & $\mathrm{CH}$ & $\mathrm{BL}$ & VA/SA & \\
\hline 770 & 780 & $\mathrm{CH}$ & $\mathrm{BL}$ & VA/SA & \\
\hline 780 & 790 & $\mathrm{LT} / \mathrm{CH}$ & $\mathrm{BL}$ & VA/SA & \\
\hline 790 & 800 & $\mathrm{LT} / \mathrm{CH}$ & $\mathrm{BL}$ & VA/SA & \\
\hline 800 & 810 & $\mathrm{DK} / \mathrm{GY}$ & $\mathrm{BL}$ & VA/SA & \\
\hline 810 & 820 & GY & $\mathrm{BL}$ & VA/SA & \\
\hline 820 & 830 & $\overline{G Y}$ & $\mathrm{BL}$ & VA/SA & \\
\hline 830 & 840 & GY & $\mathrm{BL}$ & VA/SA & \\
\hline 840 & 850 & GY & $\mathrm{BL}$ & VA/SA & \\
\hline 850 & 860 & GY & $\mathrm{BL}$ & VA/SA & \\
\hline 860 & 870 & GY & $\mathrm{BL}$ & VA/SA & \\
\hline 870 & 880 & GY & $\mathrm{BL}$ & VA/SA & \\
\hline 880 & 890 & $\overline{G Y}$ & $\mathrm{BL}$ & VA/SA & \\
\hline 890 & 900 & GY & $\mathrm{BL}$ & VA/SA & \\
\hline 900 & 910 & GY & $\mathrm{BL}$ & VA/SA & \\
\hline 910 & 920 & GY & $\mathrm{BL}$ & VA/SA & \\
\hline 920 & 930 & GY & $\mathrm{BL}$ & VA/SA & \\
\hline 930 & 940 & $\overline{G Y}$ & $\mathrm{BL}$ & VA/SA & \\
\hline 940 & 950 & GY & $\mathrm{BL}$ & VA/SA & \\
\hline 950 & 960 & GY & $\mathrm{BL}$ & VA/SA & \\
\hline 960 & 970 & GY & $\mathrm{BL}$ & VA/SA & \\
\hline 970 & 980 & GY & $\mathrm{BL}$ & VA/SA & \\
\hline 980 & 990 & GY & $\mathrm{BL}$ & VA/SA & \\
\hline 990 & 1000 & GY & $\mathrm{BL}$ & VA/SA & \\
\hline
\end{tabular}

\section{Abbrev Color $\quad$ Abbrev Round}

BL

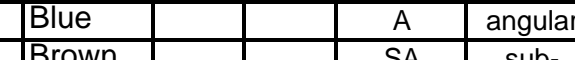

\begin{tabular}{l|l|l|l|l|l|l} 
& & & SA & sub- & angular \\
\hline $\mathrm{CH}$ & Charcoa & & & SR & sub- & rounded \\
\hline
\end{tabular}

GN $\quad$ Green

GY $\quad$ Gray

\begin{tabular}{l|l}
\hline OL & Olive \\
\hline
\end{tabular}

\begin{tabular}{|l|l|}
\hline PK & Pink \\
\hline
\end{tabular}

\begin{tabular}{l|l}
\hline PE & Purple \\
\hline RD
\end{tabular}

\begin{tabular}{|l|l|}
\hline RE & Red \\
\hline RY & Rusty \\
\hline
\end{tabular}

\begin{tabular}{|l|l|}
\hline RY & Rusty \\
\hline YL
\end{tabular}

\begin{tabular}{|l|l|}
\hline $\mathrm{RL}$ & Yellow \\
\hline
\end{tabular} |

\begin{tabular}{|l|l|l}
\hline & & \\
& & \\
& & \\
& & \\
& & \\
\hline DK & Dark & \\
\hline LT & Light & \\
\hline
\end{tabular}

\section{Mud Log}
COORDINATES
458256
E, $4513110 \mathrm{~N}$.
NAD
83
ELEV $1519 \mathrm{~m}$ AZIMUTH DIP $90^{\circ}$
LOGGED BY:
SECTION $\frac{15}{5}$ T 33N R 40E CONTRACTOR:

PAGE:

$3 \mathrm{OF} 3$

\begin{tabular}{|c|c|c|c|}
\hline \multicolumn{4}{|c|}{ WDC } \\
\hline $\begin{array}{c}\text { Phyllite } \\
\%\end{array}$ & $\begin{array}{c}\text { Mudstone } \\
\%\end{array}$ & $\begin{array}{c}\text { Sulphides } \\
\%\end{array}$ & $\begin{array}{l}\text { Qtz } \\
\%\end{array}$ \\
\hline & $\begin{array}{l}98 \\
\end{array}$ & & $\begin{array}{l}2 \\
\end{array}$ \\
\hline & $\sim 95$ & & $\sim 5$ \\
\hline & $\sim 95$ & & -5 \\
\hline & $\sim 90$ & $\operatorname{tr}$ & $\sim 10$ \\
\hline & $\sim 95$ & $\mathrm{tr}$ & -5 \\
\hline & -95 & $\operatorname{tr}$ & -5 \\
\hline & -95 & $\operatorname{tr}$ & -5 \\
\hline & -92 & $\operatorname{tr}$ & $\sim 8$ \\
\hline & $\begin{array}{l}98 \\
\end{array}$ & $\mathrm{tr}$ & $\begin{array}{l}2 \\
-2\end{array}$ \\
\hline & -98 & $\operatorname{tr}$ & $\sim 5$ \\
\hline & -96 & $\operatorname{tr}$ & $\sim 4$ \\
\hline & -96 & $\operatorname{tr}$ & $\sim 4$ \\
\hline & $\begin{array}{l}98 \\
\end{array}$ & $\mathrm{tr}$ & $\begin{array}{l}2 \\
-2\end{array}$ \\
\hline & $\sim 100$ & & $\operatorname{tr}$ \\
\hline & $\sim 99$ & $\mathrm{tr}$ & $\sim 1$ \\
\hline & $\sim 99$ & $\operatorname{tr}$ & $\sim 1$ \\
\hline & $\sim 98$ & & $\sim 2$ \\
\hline & $\sim 98$ & $\mathrm{tr}$ & $\sim 2$ \\
\hline & $\sim 98$ & $\mathrm{tr}$ & $\sim 2$ \\
\hline & $\sim 100$ & & $\operatorname{tr}$ \\
\hline & $\sim 100$ & $\mathrm{tr}$ & $\mathrm{tr}$ \\
\hline & $\sim 100$ & $\mathrm{tr}$ & $\mathrm{tr}$ \\
\hline & $\sim 100$ & & tr \\
\hline & -90 & $\operatorname{tr}$ & -10 \\
\hline & & & \\
\hline & & & \\
\hline & & & \\
\hline & & & \\
\hline & & & \\
\hline & & & \\
\hline & & & \\
\hline & & & \\
\hline & & & \\
\hline & & & \\
\hline & & & \\
\hline & & & \\
\hline & & & \\
\hline & & & \\
\hline
\end{tabular}

Abbreviation - rock/mineral type

qtz-fds-bio = quartz-feldspar-biotite

qtzites = quartzites

$\mathrm{fel}=$ felsic

volcs = volcanics

sst $=$ sandstones

ox = Fe oxidized

adds $=$ additions

\section{evers}

\begin{tabular}{l|c|l}
$<7 \mathrm{~mm}$ & chips & siliceous to weakly limey mudstones, Preble Fm., qtz veins \\
$<23 \mathrm{~mm}$ & chips & bx, siliceous to weakly limey mudstones, Preble Fm., qtz veins \\
$<17 \mathrm{~mm}$ & chips & bx, siliceous to weakly limey mudstones, Preble Fm., qtz veins
\end{tabular}

$<18 \mathrm{~mm}$ chips siliceous to weakly limey mudstones, Preble Fm., qtz veins, tr pyrite

chips silceous to weakly limey mudstones, Preble Fm., qtz veins, tr pyrite

cheste

chips siliceous, foliated mudstones, Preble Fm., qtz veins, tr pyrite

< $7 \mathrm{~mm}$ chips siliceus, foliated mudstones, Preble Fm., qtz veins, tr pyrite

chips siliceous, foliated mudstones, Preble Fm., qtz veins, tr pyrite

siliceous, foliated mudstones, Preble Fm., qtz veins

siliceous, foliated mudstones, Preble Fm., tr qtz

chips siliceous, foliated mudstones, Preble Fm., tr qtz, tr pyrite

chips siliceous, foliated mudstones, Preble Fm., tr qtz, tr pyrite

angular 
Nevada Geothermal Power Inc. and Inovision Solutions Inc

Drill hole:

PVTG-3

Fairbank Engineering Ltd. 


\section{FAIRBANK}

PVTG-3

LOCATION Pumpernickel Valley, Humboldt Co

\section{Mud Log}

ELEV 4648' $\frac{459323}{\text { AZIMUTH }}$ E, $\frac{4511695}{\text { DIP }} 90^{\circ}$ SECTION $\frac{9}{1}$ T 34N R 40E
PAGE

1 OF 5

DATE: 30.8-17.9, 2005 WDC

\begin{tabular}{|c|c|c|c|c|c|c|c|c|c|c|c|c|}
\hline \multicolumn{2}{|c|}{ DEPTH (feet) } & \multicolumn{2}{|c|}{ COLOUR } & \multicolumn{2}{|c|}{ ROUNDNESS } & \multicolumn{2}{|c|}{ GRAIN SIZE } & \multirow{2}{*}{ LITHOLOGY DESCRIPTION / COMMENTS } & \multirow{2}{*}{$\begin{array}{l}\text { Meta- } \\
\text { Seds \% }\end{array}$} & \multirow{2}{*}{$\begin{array}{c}\text { Intrusives } \\
\%\end{array}$} & \multirow{2}{*}{$\begin{array}{c}\text { Volcanics } \\
\%\end{array}$} & \multirow{2}{*}{$\begin{array}{l}\text { Qtz } \\
\%\end{array}$} \\
\hline From & To & 1 & 2 & Angular & Rounded & Range & Class & & & & & \\
\hline 0 & 10 & BG & GY & & & $<1.5 \mathrm{~mm}$ & $\mathrm{~F}$ & soil, small $\%$ of fine and medium sand & & & & \\
\hline 10 & 20 & BG & GY & SA & SR & $<4 \mathrm{~mm}$ & FG & soil, small \% of fine and medium sand, few granules & & & & \\
\hline 20 & 30 & BG & GY & SA & $\mathrm{SR}$ & $<15 \mathrm{~mm}$ & MG & soil with clay, silt, and sand, pebbles of metaseds and intrusives & & & & \\
\hline 30 & 40 & BG & GY & & & $<1.5 \mathrm{~mm}$ & $\mathrm{~F}$ & soil, small $\%$ of fine and medium sand & & & & \\
\hline 40 & 50 & BG & GY & & & $<1.5 \mathrm{~mm}$ & $\mathrm{~F}$ & soil, small $\%$ of fine and medium sand & & & & \\
\hline 50 & 60 & BG & GY & SA & SR & $<8 \mathrm{~mm}$ & FG & soil with clay, silt, and sand; pebbles of metaseds, intrusives, quartz & & & & \\
\hline 60 & 70 & BG & GY & SA & SR & $<8 \mathrm{~mm}$ & FG & soil with clay, silt, and sand; pebbles of metaseds, intrusives, quartz & & & & \\
\hline 70 & 80 & BG & GY & $\overline{\mathrm{SA}}$ & $\overline{\mathrm{SR}}$ & $<8 \mathrm{~mm}$ & FG & soil with clay, silt, and sand; pebbles of metaseds, intrusives, quartz & & & & \\
\hline 80 & 90 & BG & DK & $\mathrm{SA}$ & $\mathrm{SR}$ & $<8 \mathrm{~mm}$ & FG & soil with clay, silt, and sand; pebbles of metaseds, intrusives, quartz & & & & \\
\hline 90 & 100 & BG & GY & $\mathrm{SA}$ & $\mathrm{R}$ & $<6 \mathrm{~mm}$ & FG & soil with clay, silt, and sand; pebbles of metaseds, intrusives, quartz & & & & \\
\hline 100 & 110 & BG & & SA & $\bar{R}$ & $<10 \mathrm{~mm}$ & $\overline{M G}$ & clay, silt, and sand; pebbles of felsic intrusives, metaseds, and quartz & $\sim 40$ & $\sim 50$ & & 10 \\
\hline 110 & 120 & BG & GY & $\overline{S A}$ & $\overline{S R}$ & $<25 \mathrm{~mm}$ & $\overline{C G}$ & clay, silt, and sand; pebbles of metaseds, felsic intrusives, and quartz & $\sim 50$ & $\sim 45$ & & 5 \\
\hline 120 & 130 & BG & LT & & & & $\mathrm{F}$ & clay and silt supported fine sand & & & & \\
\hline 130 & 140 & $\mathrm{BN}$ & LT & & & & $\mathrm{F}$ & clay and silt supported fine sand & & & & \\
\hline 140 & 150 & BG & LT & & & & $\mathrm{F}$ & clay and silt supported fine sand & & & & \\
\hline 150 & 160 & BG & & & & & $\mathrm{F}$ & clay and silt supported sand & & & & \\
\hline 160 & 170 & BG & & & & & $\mathrm{F}$ & clay and silt supported fine sand & & & & \\
\hline 170 & 180 & BG & & & & & $\mathrm{F}$ & clay and silt supported fine sand & & & & \\
\hline 180 & 190 & BG & DK & & & & $\mathrm{F}$ & clay and silt supported fine sand & & & & \\
\hline 190 & 200 & & & & & & & no sample & & & & \\
\hline 200 & 210 & GY & BG & $\overline{S A}$ & SR & $<12 \mathrm{~mm}$ & MG & metaseds, Preble Fm.(?), qtz-fds-bio granite, and quartz & $\sim 55$ & $\sim 40$ & & 5 \\
\hline 210 & 220 & BG & GY & SA & SR & $<8 \mathrm{~mm}$ & FG & metaseds, Preble Fm.(?), qtz-fds-bio granite, and quartz & -35 & $\sim 65$ & & 10 \\
\hline 220 & 230 & BG & GY & $\overline{\mathrm{SA}}$ & SR & $<8 \mathrm{~mm}$ & FG & metaseds, Preble Fm.(?), qtz-fds-bio granite, and quartz & $\sim 42$ & $\sim 50$ & & 8 \\
\hline 230 & 240 & $\mathrm{BG}$ & DK & SA & SR & $<7 \mathrm{~mm}$ & FG & metaseds, Preble Fm.(?), qtz-fds-bio granite, and quartz & $\sim 35$ & $\sim 60$ & & 5 \\
\hline 240 & 250 & BG & GY & $\overline{S A}$ & SR & $<7 \mathrm{~mm}$ & FG & metaseds, Preble Fm.(?), qtz-fds-bio granite, and quartz & $\sim 20$ & $\sim 65$ & & 15 \\
\hline 250 & 260 & GY & BG & $\overline{\mathrm{SA}}$ & SR & $<9 \mathrm{~mm}$ & MG & metaseds, Preble Fm.(?), qtz-fds-bio granite, and quartz & $\sim 55$ & $\sim 40$ & & 5 \\
\hline 260 & 270 & GY & $\mathrm{BN}$ & $\overline{S A}$ & SR & $<9 \mathrm{~mm}$ & MG & metaseds, Preble Fm.(?), qtz-fds-bio granite, and quartz & -30 & $\sim 60$ & & 10 \\
\hline 270 & 280 & GY & $\mathrm{BN}$ & SA & SR & $<9 \mathrm{~mm}$ & MG & metaseds, Preble Fm.(?), qtz-fds-bio granite, and quartz & $\sim 65$ & $\sim 25$ & & 10 \\
\hline 280 & 290 & GY & $\mathrm{BN}$ & $\overline{S A}$ & SR & $<10 \mathrm{~mm}$ & MG & metaseds, Preble Fm.(?), qtz-fds-bio granite, and quartz & $\sim 57$ & $\sim 35$ & & 8 \\
\hline 290 & 300 & $\mathrm{BG}$ & DK & SA & SR & $<10 \mathrm{~mm}$ & MG & metaseds, Preble Fm.(?), qtz-fds-bio granite, and quartz & $\sim 55$ & $\sim 35$ & & 10 \\
\hline 300 & 310 & $\mathrm{BN}$ & $\mathrm{LT}$ & $\mathrm{SA}$ & $\mathrm{SR}$ & $<8 \mathrm{~mm}$ & FG & metaseds, Preble Fm.(?), qtz-fds-bio granite, and quartz & $\sim 70$ & -25 & & 5 \\
\hline 310 & 320 & GY & BG & $\mathrm{SA}$ & $\mathrm{R}$ & $<8 \mathrm{~mm}$ & FG & metaseds, Preble Fm.(?), qtz-fds-bio granite, and quartz & -28 & $\sim 60$ & & 12 \\
\hline 320 & 330 & BG & DK & SA & SR & $<7 \mathrm{~mm}$ & FG & metaseds, Preble Fm.(?), qtz-fds-bio granite, and quartz & $\sim 20$ & $\sim 70$ & & 10 \\
\hline 330 & 340 & GY & BG & SA & SR & $<9 \mathrm{~mm}$ & MG & metaseds, Preble Fm.(?), qtz-fds-bio granite, and quartz & $\sim 50$ & $\sim 40$ & & 10 \\
\hline 340 & 350 & GY & $\mathrm{BN}$ & $\mathrm{SA}$ & $\mathrm{R}$ & $<12 \mathrm{~mm}$ & MG & metaseds, Preble Fm.(?), qtz-fds-bio granite, and quartz & $\sim 62$ & $\sim 30$ & & 8 \\
\hline 350 & 360 & GY & $\mathrm{BN}$ & $\mathrm{SA}$ & SR & $<11 \mathrm{~mm}$ & MG & metaseds, Preble Fm.(?), qtz-fds-bio granite, and quartz & -35 & $\sim 60$ & & 5 \\
\hline 360 & 370 & GY & $\mathrm{BN}$ & $\mathrm{SA}$ & SR & $<9 \mathrm{~mm}$ & MG & metaseds, Preble Fm.(?), qtz-fds-bio granite, and quartz & $\sim 32$ & $\sim 60$ & & 8 \\
\hline 370 & 380 & GY & BG & SA & SR & $<10 \mathrm{~mm}$ & $\overline{F G}$ & metaseds, Preble Fm.(?), qtz-fds-bio granite, and quartz & $\sim 45$ & $\sim 45$ & & 10 \\
\hline
\end{tabular}




\section{FAIRBANK}

PROJECT

HOLE NO. PUTG-3

LOCATION Pumpernickel Valley

\section{Mud Log}

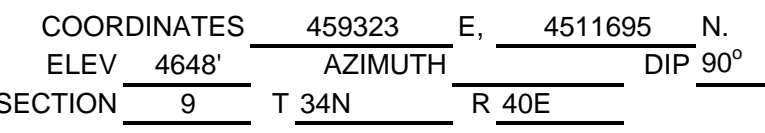
NAD $\frac{83}{\text { LOGGED BY: }}$
CONTRACTOR:

PAGE:

2 OF 5

DATE: $30.8-17.9,2005$ SECTION

\begin{tabular}{|c|c|c|c|c|c|c|c|c|c|c|c|c|}
\hline \multicolumn{2}{|c|}{ LOCATION } & \multicolumn{4}{|c|}{ Pumpernickel Valley } & \multicolumn{2}{|c|}{ SECTION } & CONTRACTOR: & \multicolumn{4}{|c|}{ WDC } \\
\hline \multicolumn{2}{|c|}{ DEPTH (feet) } & \multicolumn{2}{|c|}{ COLOUR } & \multicolumn{2}{|c|}{ ROUNDNESS } & \multicolumn{2}{|c|}{ GRAIN SIZE } & \multirow{2}{*}{ LITHOLOGY DESCRIPTION / COMMENTS } & \multirow{2}{*}{$\begin{array}{c}\text { Meta- } \\
\text { Seds \% }\end{array}$} & \multirow{2}{*}{$\begin{array}{c}\text { Intrusives } \\
\%\end{array}$} & \multirow{2}{*}{$\begin{array}{c}\text { Volcanics } \\
\%\end{array}$} & \multirow{2}{*}{$\begin{array}{l}\text { Qtz } \\
\%\end{array}$} \\
\hline From & To & 1 & 2 & Angular & Rounded & Range & Class & & & & & \\
\hline 380 & 390 & GY & BG & SA & SR & $<8 \mathrm{~mm}$ & FG & metaseds, Preble Fm.(?), qtz-fds-bio granite, and quartz & $\sim 60$ & $\sim 25$ & & 15 \\
\hline 390 & 400 & GY & BG & SA & SR & $<5 \mathrm{~mm}$ & $\mathrm{FG}$ & metaseds, Preble Fm.(?), qtz-fds-bio granite, and quartz & -55 & -30 & & 15 \\
\hline 400 & 410 & GY & BG & SA & $\mathrm{SR}$ & $<6 \mathrm{~mm}$ & FG & metaseds, Preble Fm.(?), qtz-fds-bio granite, and quartz & $\sim 50$ & $\sim 40$ & & 10 \\
\hline 410 & 420 & GY & $\mathrm{BN}$ & SA & $\mathrm{SR}$ & $<14 \mathrm{~mm}$ & MG & metaseds, Preble Fm.(?), qtz-fds-bio granite, and quartz & -52 & $\sim 40$ & & 8 \\
\hline 420 & 430 & GY & $\mathrm{BN}$ & SA & $\mathrm{R}$ & $<8 \mathrm{~mm}$ & FG & metaseds, Preble Fm.(?), qtz-fds-bio granite, and quartz & -30 & $\sim 60$ & & 10 \\
\hline 430 & 440 & GY & $\mathrm{BN}$ & $\mathrm{SA}$ & $\mathrm{R}$ & $<9 \mathrm{~mm}$ & MG & metaseds, Preble Fm.(?), qtz-fds-bio granite, and quartz & -60 & -25 & & 15 \\
\hline 440 & 450 & $\mathrm{BN}$ & & & & & & bad sample & & & & \\
\hline 450 & 460 & GY & $\mathrm{BN}$ & A & SR & $<12 \mathrm{~mm}$ & MG & metaseds, Preble Fm.(?), qtz-fds-bio granite, and quartz & $\sim 60$ & -25 & & 15 \\
\hline 460 & 470 & $\mathrm{BN}$ & PK & SA & SR & $<13 \mathrm{~mm}$ & MG & metaseds, Preble Fm.(?), qtz-fds-bio granite, and quartz & $\sim 45$ & $\sim 50$ & & 5 \\
\hline 470 & 480 & BN & PK & SA & SR & $<11 \mathrm{~mm}$ & MG & metaseds, Preble Fm.(?), qtz-fds-bio granite, and quartz & $\sim 55$ & -30 & & 15 \\
\hline 480 & 490 & $\mathrm{BN}$ & PK & SA & $\mathrm{R}$ & $<9 \mathrm{~mm}$ & MG & metaseds, Preble Fm.(?), qtz-fds-bio granite, and quartz & $\sim 65$ & -30 & & 5 \\
\hline 490 & 500 & GY & $\mathrm{BN}$ & SA & SR & $<11 \mathrm{~mm}$ & MG & metaseds, Preble Fm.(?), qtz-fds-bio granite, and quartz & $\sim 82$ & 15 & & 3 \\
\hline 500 & 510 & GY & $\mathrm{BN}$ & SA & SR & $<9 \mathrm{~mm}$ & MG & metaseds, Preble Fm.(?), qtz-fds-bio granite, and quartz & $\sim 75$ & 15 & & 10 \\
\hline 510 & 520 & GY & BN & SA & SR & $<7 \mathrm{~mm}$ & FG & metaseds, Preble Fm.(?), qtz-fds-bio granite, and quartz & $\sim 77$ & 15 & & 8 \\
\hline 520 & 530 & GY & $\mathrm{BN}$ & & SR & $<13 \mathrm{~mm}$ & MG & metaseds, Preble Fm.(?), qtz-fds-bio granite, and quartz & $\sim 85$ & 10 & & $<5$ \\
\hline 530 & 540 & GY & & SA & $\overline{S R}$ & $<10 \mathrm{~mm}$ & MG & grey quartzite, Preble Fm.(?); lesser qtz-fds-bio granite and quartz & $\sim 85$ & $<10$ & & $<5$ \\
\hline 540 & 550 & GY & & SA & & $<15 \mathrm{~mm}$ & MG & grey quartzite, Preble Fm.(?); lesser qtz-fds-bio granite and quartz & $\sim 90$ & 5 & & 5 \\
\hline 550 & 560 & GY & PK & SA & SR & $<10 \mathrm{~mm}$ & MG & grey quartzite, Preble Fm.(?); lesser qtz-fds-bio granite and quartz & $\sim 77$ & 18 & & 5 \\
\hline 560 & 570 & GY & $\mathrm{PK}$ & SA & SR & $<12 \mathrm{~mm}$ & MG & grey quartzite, Preble Fm.(?); lesser qtz-fds-bio granite and quartz & $\sim 80$ & 15 & & 5 \\
\hline 570 & 580 & GY & $\mathrm{PK}$ & SA & $\mathrm{SR}$ & $<15 \mathrm{~mm}$ & MG & grey quartzite, Preble Fm.(?); lesser qtz-fds-bio granite and quartz & $\sim 84$ & 8 & & 8 \\
\hline 580 & 590 & GY & & SA & $\overline{S R}$ & $<13 \mathrm{~mm}$ & MG & grey quartzite, Preble Fm.(?); lesser qtz-fds-bio granite and quartz & $\sim 87$ & 5 & & 8 \\
\hline 590 & 600 & & & & & & & no sample & & & & \\
\hline 600 & 610 & GY & PK & SA & $\mathrm{SR}$ & $<11 \mathrm{~mm}$ & MG & grey quartzite, Preble Fm.(?); lesser qtz-fds-bio granite and quartz & $\sim 84$ & 8 & & 8 \\
\hline 610 & 620 & GY & PK & SA & SR & $<15 \mathrm{~mm}$ & MG & grey quartzite, Preble Fm.(?); lesser qtz-fds-bio granite and quartz & $\sim 90$ & 5 & & 5 \\
\hline 620 & 630 & GY & PK & SA & $\mathrm{SR}$ & $<16 \mathrm{~mm}$ & MG & grey qtzite; lesser qtz-fds-bio granite, Tertiary volcanics, and quartz & $\sim 87$ & 5 & 3 & $<5$ \\
\hline 630 & 640 & GY & BG & SA & SR & $<16 \mathrm{~mm}$ & MG & grey quartzite, Preble Fm.(?); lesser qtz-fds-bio granite and quartz & $\sim 90$ & 5 & & $<5$ \\
\hline 640 & 650 & GY & BG & SA & SR & $<18 \mathrm{~mm}$ & CG & grey quartzite, Preble Fm.(?); lesser qtz-fds-bio granite and quartz & $\sim 87$ & 5 & & 8 \\
\hline 650 & 660 & GY & & SA & SR & $<16 \mathrm{~mm}$ & MG & grey quartzite (Preble Fm.?) & $\sim 100$ & & & \\
\hline 660 & 670 & GY & BG & SA & $\mathrm{SR}$ & $<15 \mathrm{~mm}$ & MG & grey quartzite (Preble Fm.?), lesser qtz-fds-bio granite & $>95$ & 5 & & \\
\hline 670 & 680 & GY & & SA & SR & $<14 \mathrm{~mm}$ & MG & grey quartzite (Preble Fm.?) & $\sim 100$ & & & \\
\hline 680 & 690 & GY & PK & SA & SR & $<14 \mathrm{~mm}$ & MG & grey quartzite, Preble Fm.(?); lesser qtz-fds-bio granite and quartz & $\sim 87$ & 8 & & 5 \\
\hline 690 & 700 & GY & PK & SA & SR & $<13 \mathrm{~mm}$ & MG & grey quartzite (Preble Fm.?), lesser qtz-fds-bio granite & -92 & 8 & & \\
\hline 700 & 710 & GY & BN & SA & SR & $<14 \mathrm{~mm}$ & MG & grey quartzite, Preble Fm.(?); lesser qtz-fds-bio granite and quartz & $\sim 87$ & 5 & & 8 \\
\hline 710 & 720 & GY & $\mathrm{BN}$ & SA & SR & $<11 \mathrm{~mm}$ & MG & grey quartzite, Preble Fm.(?); lesser qtz-fds-bio granite and quartz & $\sim 94$ & 3 & & 3 \\
\hline 720 & 730 & GY & $\mathrm{BN}$ & SA & $\mathrm{SR}$ & $<13 \mathrm{~mm}$ & MG & grey quartzite, Preble Fm.(?); lesser quartz & $\sim 95$ & & & 5 \\
\hline 730 & 740 & GY & BG & SA & SR & $<17 \mathrm{~mm}$ & CG & grey quartzite (Preble Fm.?), minor qtz-fds-bio granite & $\sim 97$ & $<3$ & & \\
\hline 740 & 750 & GY & BG & SA & $\mathrm{SR}$ & $<12 \mathrm{~mm}$ & MG & grey quartzite, minor qtz-fds-bio granite and quartz & $\sim 98$ & $<3$ & & $<3$ \\
\hline 750 & 760 & GY & BG & SA & SR & $<7 \mathrm{~mm}$ & FG & grey quartzite, Preble Fm.(?); lesser quartz & -95 & & & 5 \\
\hline
\end{tabular}




\section{FAIRBANK \\ PROJECT}

Pumpernickel Valley

LOCATION

\section{Mud Log}

ELEV 4648' $\frac{459323}{\text { AZIMUTH }}{ }^{\circ} \frac{4511695}{\mathrm{DIP}} 90^{\circ}$

NAD

83

LOGGED BY: SECTION
PAGE:

3 OF 5

PATE: 30.8-17.9, 2005 WDC

\begin{tabular}{|c|c|c|c|c|c|c|c|c|c|c|c|c|}
\hline \multicolumn{2}{|c|}{ DEPTH (feet) } & \multicolumn{2}{|c|}{ COLOUR } & \multicolumn{2}{|c|}{ ROUNDNESS } & \multicolumn{2}{|c|}{ GRAIN SIZE } & \multirow{2}{*}{ LITHOLOGY DESCRIPTION / COMMENTS } & \multirow{2}{*}{$\begin{array}{l}\text { Meta- } \\
\text { Seds \% }\end{array}$} & \multirow{2}{*}{$\begin{array}{c}\text { Intrusive } \\
\%\end{array}$} & \multirow{2}{*}{$\begin{array}{c}\text { Volcanics } \\
\%\end{array}$} & \multirow[t]{2}{*}{ Qtz \% } \\
\hline From & To & 1 & 2 & Angular & Rounded & Range & Class & & & & & \\
\hline 760 & 770 & GY & PK & SA & SR & $<15 \mathrm{~mm}$ & MG & grey quartzite, Preble Fm.(?); lesser qtz-fds-bio granite and quartz & -92 & 3 & & 5 \\
\hline 770 & 780 & GY & PK & SA & SR & $<9 \mathrm{~mm}$ & MG & grey qtzite; lesser felsic intrusives and volcanics, and quartz & -87 & 3 & 2 & 8 \\
\hline 780 & 790 & GY & $\mathrm{PK}$ & SA & SR & $<8 \mathrm{~mm}$ & FG & grey quartzite; lesser qtz-fds-bio granite and quartz & $\sim 93$ & 2 & & 5 \\
\hline 790 & 800 & GY & $\mathrm{PK}$ & SA & SR & $<6 \mathrm{~mm}$ & FG & grey qtzite; lesser quartz & $\sim 97$ & & & $<3$ \\
\hline 800 & 810 & GY & $\mathrm{BN}$ & SA & SR & $<10 \mathrm{~mm}$ & MG & grey quartzite; lesser qtz-fds-bio granite and quartz & $\sim 88$ & 2 & & 10 \\
\hline 810 & 820 & GY & $\mathrm{PK} / \mathrm{BG}$ & SA & SR & $<7 \mathrm{~mm}$ & FG & grey quartzite; lesser qtz-fds-bio granite and quartz & $\sim 93$ & 2 & & 5 \\
\hline 820 & 830 & GY & $\mathrm{PK} / \mathrm{BG}$ & SA & SR & $<9 \mathrm{~mm}$ & MG & grey qtzite; lesser quartz & $\sim 90$ & & & 10 \\
\hline 830 & 840 & GY & $\mathrm{PK} / \mathrm{BG}$ & SA & SR & $<9 \mathrm{~mm}$ & MG & grey qtzite; minor felsic intrusives and volcanics, and quartz & $\sim 92$ & 3 & 2 & 3 \\
\hline 840 & 850 & GY & BG & SA & SR & $<12 \mathrm{~mm}$ & MG & grey quartzite, Preble Fm.(?); lesser qtz-fds-bio granite and quartz & $\sim 89$ & $\sim 1$ & & 10 \\
\hline 850 & 860 & GY & PK & SA & SR & $<8 \mathrm{~mm}$ & FG & grey quartzite, Preble Fm.(?); lesser qtz-fds-bio granite and quartz & $\sim 93$ & 2 & & 5 \\
\hline 860 & 870 & GY & $\mathrm{PK}$ & SA & SR & $<7 \mathrm{~mm}$ & FG & grey quartzite, Preble Fm.(?); lesser qtz-fds-bio granite and quartz & $\sim 87$ & 5 & & 8 \\
\hline 870 & 880 & GY & DK/BG & SA & SR & $<7 \mathrm{~mm}$ & FG & grey quartzite, Preble Fm.(?); lesser qtz-fds-bio granite and quartz & $\sim 90$ & 5 & & 5 \\
\hline 880 & 890 & GY & DK/BG & SA & SR & $<8 \mathrm{~mm}$ & FG & grey qtzite; minor felsic intrusives and volcanics, and quartz & $\sim 92$ & 2 & 1 & 5 \\
\hline 890 & 900 & GY & $\mathrm{DK} / \mathrm{BG}$ & $\mathrm{SA}$ & $\mathrm{R}$ & $<9 \mathrm{~mm}$ & MG & grey qtzite; minor felsic intrusives and volcanics, and quartz & $\sim 91$ & 3 & 1 & 5 \\
\hline 900 & 910 & GY & LT/BG & SA & SR & $<5 \mathrm{~mm}$ & FG & grey qtzite;minor quartz & $\sim 98$ & & & 2 \\
\hline 910 & 920 & GY & DK & $\mathrm{SA}$ & SR & $<17 \mathrm{~mm}$ & CG & grey qtzite;minor quartz & $\sim 98$ & & & 2 \\
\hline 920 & 930 & GY & BG & SA & SR & $<17 \mathrm{~mm}$ & CG & grey qtzite;minor quartz & -95 & & & 5 \\
\hline 930 & 940 & GY & DK & $\overline{\mathrm{SA}}$ & $\overline{\mathrm{SR}}$ & $<16 \mathrm{~mm}$ & MG & grey qtzite;minor quartz & $\sim 97$ & & & 3 \\
\hline 940 & 950 & GY & $\mathrm{PK}$ & SA & SR & $<14 \mathrm{~mm}$ & MG & grey qtzite, Preble Fm., adds minor fel intrusives and qtz & $\sim 94$ & 1 & & 5 \\
\hline 950 & 960 & GY & $\mathrm{PK}$ & $\overline{\mathrm{SA}}$ & SR & $<10 \mathrm{~mm}$ & $M G$ & grey qtzite;minor quartz & $\sim 97$ & & & 3 \\
\hline 960 & 970 & GY & PK & SA & SR & $<11 \mathrm{~mm}$ & MG & grey qtzite, Preble Fm., adds minor fel intrusives and qtz & $\sim 93$ & 2 & & 5 \\
\hline 970 & 980 & GY & BG & SA & SR & $<15 \mathrm{~mm}$ & MG & grey qtzite, Preble Fm., adds minor fel intrusives and qtz & $\sim 87$ & 8 & & 5 \\
\hline 980 & 990 & GY & BG & SA & $\mathrm{SR}$ & $<9 \mathrm{~mm}$ & MG & grey qtzite; lesser felsic intrusives and volcanics, and quartz & $\sim 82$ & 5 & 5 & 8 \\
\hline 990 & 1000 & GY & BG & SA & $\mathrm{SR}$ & $<7 \mathrm{~mm}$ & FG & grey qtzite; lesser felsic intrusives and volcanics, and quartz & $\sim 80$ & 10 & 5 & 5 \\
\hline 1000 & 1010 & GY & $\mathrm{BG} / \mathrm{PK}$ & SA/A & SR & $<18 \mathrm{~mm}$ & CG & qtzites, qtz schists, cherts; lesser felsic volcanics and intrusives, qtz & $\sim 68$ & 17 & 10 & 5 \\
\hline 1010 & 1020 & GY & $\mathrm{BG} / \mathrm{PK}$ & SA & SR & $<13 \mathrm{~mm}$ & MG & qtzites, qtz schists, cherts; lesser felsic volcanics and intrusives, qtz & $\sim 77$ & 5 & 10 & 8 \\
\hline 1020 & 1030 & GY & $\mathrm{BG} / \mathrm{PK}$ & SA & $\mathrm{SR} / \mathrm{R}$ & $<7 \mathrm{~mm}$ & FG & qtzites, qtz schists, cherts; lesser felsic volcanics and intrusives, qtz & $\sim 87$ & $<5$ & $<3$ & 5 \\
\hline 1030 & 1040 & GY & BG/PK & SA & SR & $<15 \mathrm{~mm}$ & MG & qtzites, qtz schists, cherts; lesser felsic volcanics and intrusives, qtz & $\sim 77$ & 10 & 8 & 5 \\
\hline 1040 & 1050 & GY & $\mathrm{BG} / \mathrm{PK}$ & A/SA & SR & $<7 \mathrm{~mm}$ & FG & qtzites, qtz schists, cherts; lesser intrusives and qtz & $\sim 85$ & 10 & & 5 \\
\hline 1050 & 1060 & GY & $\mathrm{BG} / \mathrm{PK}$ & A/SA & SR & $<9 \mathrm{~mm}$ & MG & qtzites, qtz schists, cherts; lesser felsic volcanics and intrusives, qtz & $\sim 81$ & 8 & 3 & 8 \\
\hline 1060 & 1070 & GY & BG/PK & $\mathrm{SA}$ & SR & $<15 \mathrm{~mm}$ & MG & qtzites, qtz schists, cherts; lesser felsic volcanics and intrusives, qtz & $\sim 87$ & 5 & 3 & 5 \\
\hline 1070 & 1080 & GY & BG/PK & SA & $\mathrm{SR}$ & $<5 \mathrm{~mm}$ & FG & qtzites, qtz schists, cherts; lesser felsic volcanics and intrusives, qtz & $\sim 77$ & 10 & 3 & 10 \\
\hline 1080 & 1090 & GY & BG/PK & SA & SR & $<6 \mathrm{~mm}$ & FG & qtzites, qtz schists; some felsic intrusives and qtz & $\sim 72$ & 8 & & 20 \\
\hline 1090 & 1100 & GY & $\mathrm{BG} / \mathrm{PK}$ & SA & $\mathrm{SR}$ & $<7 \mathrm{~mm}$ & FG & qtzites, qtz schists; lesser felsic intrusives and qtz & $\sim 78$ & 12 & & 10 \\
\hline 1100 & 1110 & GY & PK & SA & SR & $<10 \mathrm{~mm}$ & MG & qtzites, qtz schists; lesser felsic intrusives and qtz & $\sim 87$ & 5 & & 8 \\
\hline 1110 & 1120 & GY & BG & SA & $\mathrm{SR}$ & $<7 \mathrm{~mm}$ & FG & qtzites, qtz schists; lesser felsic intrusives and qtz & $\sim 75$ & 15 & & 10 \\
\hline 1120 & 1130 & GY & BG & SA & $\mathrm{SR}$ & $<8 \mathrm{~mm}$ & FG & qtzites, qtz schists; lesser felsic intrusives and qtz & $\sim 90$ & 5 & & 5 \\
\hline 1130 & 1140 & GY & BG & $\mathrm{SA}$ & $\mathrm{SR}$ & $<8 \mathrm{~mm}$ & FG & qtzites, qtz schists; lesser felsic volcanics and intrusives, qtz & $\sim 89$ & 5 & 1 & 5 \\
\hline
\end{tabular}




\section{FAIRBANK \\ PROJECT}

HOLE NO.

Pumpernickel Valley

PVTG-3

LOCATION

Pumpernickel Valley

\section{Mud Log}

ELEV 4648' $\frac{459323}{\text { AZIMUTH }}{ }^{\circ} \frac{4511695}{\text { DIP }} 90^{\circ}$

NAD

83

LOGGED BY: SECTION

PAGE:

4 OF 5

DATE: $30.8-17.9,2005$ Adam Szybinski WDC

\begin{tabular}{|c|c|c|c|c|c|c|c|c|c|c|c|c|}
\hline \multicolumn{2}{|c|}{ DEPTH (feet) } & \multicolumn{2}{|c|}{ COLOUR } & \multicolumn{2}{|c|}{ ROUNDNESS } & \multicolumn{2}{|c|}{ GRAIN SIZE } & \multirow{2}{*}{ LITHOLOGY DESCRIPTION / COMMENTS } & \multirow{2}{*}{$\begin{array}{l}\text { Meta- } \\
\text { Seds \% }\end{array}$} & \multirow{2}{*}{$\begin{array}{c}\text { Intrusive } \\
\%\end{array}$} & \multirow{2}{*}{$\begin{array}{c}\text { Volcanics } \\
\%\end{array}$} & \multirow[t]{2}{*}{ Qtz \% } \\
\hline From & To & 1 & 2 & Angular & Rounded & Range & Class & & & & & \\
\hline 1140 & 1150 & GY & BG & SA & SR & $<7 \mathrm{~mm}$ & FG & qtzites, qtz schists; lesser fel volcanics and intrusives, qtz & $\sim 83$ & 8 & 1 & 8 \\
\hline 1150 & 1160 & GY & BG & SA & SR & $<8 \mathrm{~mm}$ & FG & qtzites, qtz schists; lesser fel volcanics and intrusives, qtz & $\sim 84$ & 5 & 3 & 8 \\
\hline 1160 & 1170 & GY & BG & $\overline{S A}$ & SR & $<6 \mathrm{~mm}$ & FG & qtzites, qtz schists; lesser fel intrusives, qtz & $\sim 90$ & 5 & & 5 \\
\hline 1170 & 1180 & GY & PK/BG & $\overline{S A}$ & SR & $<6 \mathrm{~mm}$ & FG & qtzites, qtz schists; lesser fel intrusives, qtz & $\sim 89$ & $<3$ & & 8 \\
\hline 1180 & 1190 & BG & GY & $\overline{S A}$ & SR & $<5 \mathrm{~mm}$ & FG & qtzites, qtz schists; lesser fel intrusives, qtz & $\sim 90$ & 5 & & 5 \\
\hline 1190 & 1200 & $\mathrm{GY}$ & $\mathrm{BG}$ & $\overline{\mathrm{SA}}$ & $\overline{\mathrm{SR}}$ & $<6 \mathrm{~mm}$ & FG & qtzites, qtz schists; lesser fel intrusives, qtz & -80 & 12 & & 8 \\
\hline 1200 & 1210 & GY & $\mathrm{BN}$ & $\mathrm{SA}$ & SR & $<7 \mathrm{~mm}$ & FG & qtzites, qtz schists; lesser fel intrusives, qtz & -82 & 8 & & 10 \\
\hline 1210 & 1220 & GY & $\mathrm{BN}$ & $\overline{\mathrm{SA}}$ & $\overline{\mathrm{SR}}$ & $<6 \mathrm{~mm}$ & FG & qtzites, qtz schists; lesser fel volcanics and intrusives, qtz & -92 & 5 & 7 & 8 \\
\hline 1220 & 1230 & GY & $\mathrm{BN}$ & $\mathrm{SA}$ & SR & $<7 \mathrm{~mm}$ & FG & qtzites, qtz schists; lesser fel volcanics and intrusives, qtz & -84 & 3 & 3 & 10 \\
\hline 1230 & 1240 & GY & $\mathrm{BN}$ & $\overline{\mathrm{SA}}$ & $\overline{\mathrm{SR}}$ & $<13 \mathrm{~mm}$ & MG & qtzites, qtz schists; lesser fel intrusives, qtz & $\sim 83$ & 5 & & 12 \\
\hline 1240 & 1250 & GY & $\mathrm{BN}$ & $\overline{\mathrm{SA}}$ & SR & $<7 \mathrm{~mm}$ & FG & qtzites, qtz schists; lesser fel intrusives, qtz & -83 & $<5$ & & 12 \\
\hline 1250 & 1260 & GY & $\overline{\mathrm{BN}}$ & $\overline{\mathrm{SA}}$ & $\overline{S R / R}$ & $<9 \mathrm{~mm}$ & MG & qtzites, qtz schists; lesser fel intrusives, qtz & -90 & & & 10 \\
\hline 1260 & 1270 & GY & PK/BG & $\mathrm{SA}$ & SR & $<8 \mathrm{~mm}$ & FG & qtzites, qtz schists; lesser fel volcanics and intrusives, qtz & -86 & $<3$ & 1 & 10 \\
\hline 1270 & 1280 & GY & $\mathrm{BN}$ & SA & SR & $<6 \mathrm{~mm}$ & FG & qtzites, qtz schists; lesser fel volcanics and intrusives, qtz & -91 & 1 & 10 & 8 \\
\hline 1280 & 1290 & GY & $B G$ & $\mathrm{SA}$ & SR & $<8 \mathrm{~mm}$ & FG & qtzites, qtz schists; lesser fel volcanics and intrusives, qtz & $\sim 84$ & 3 & 3 & 10 \\
\hline 1290 & 1300 & $\mathrm{BN}$ & GY & $\mathrm{SA}$ & SR & $<8 \mathrm{~mm}$ & CG & qtzites, qtz schists; lesser fel volcanics and intrusives, qtz & $\sim 86$ & 3 & 3 & 8 \\
\hline 1300 & 1310 & GY & $\mathrm{PK}$ & SA & $\mathrm{SR}$ & $<10 \mathrm{~mm}$ & MG & qtzites, qtz schists; lesser fel volcanics and intrusives, qtz & -85 & 2 & 5 & 8 \\
\hline 1310 & 1320 & GY & BG & $\mathrm{SA}$ & SR & $<10 \mathrm{~mm}$ & MG & qtzites, qtz schists; lesser fel volcanics and intrusives, qtz & $\sim 85$ & 5 & 5 & 5 \\
\hline 1320 & 1330 & GY & $\mathrm{PK} / \mathrm{BG}$ & $\mathrm{SA}$ & SR & $<10 \mathrm{~mm}$ & MG & qtzites, qtz schists; lesser fel volcanics and intrusives, qtz & $\sim 94$ & 8 & 3 & $<3$ \\
\hline 1330 & 1340 & BG & & $\mathrm{SA}$ & SR & $<10 \mathrm{~mm}$ & MG & qtzites, qtz schists; lesser fel volcanics and qtz & $\sim 97$ & & 12 & 3 \\
\hline 1340 & 1350 & GY & BG & SA & $\mathrm{SR}$ & $<7 \mathrm{~mm}$ & FG & qtzites, qtz schists; lesser fel volcanics and qtz & 293 & & 8 & 5 \\
\hline 1350 & 1360 & GY & $\mathrm{PK} / \mathrm{BG}$ & $\mathrm{SA}$ & SR & $<9 \mathrm{~mm}$ & MG & qtzites, qtz schists; lesser fel volcanics and intrusives, qtz & $\sim 84$ & 3 & 5 & 8 \\
\hline 1360 & 1370 & $\overline{G Y}$ & $B G$ & $\overline{S A}$ & $\overline{\mathrm{SR}}$ & $<9 \mathrm{~mm}$ & MG & qtzites, qtz schists; lesser fel intrusives, qtz & -89 & 3 & & 8 \\
\hline 1370 & 1380 & GY & $\mathrm{BN}$ & $\overline{\mathrm{SA}}$ & SR & $<11 \mathrm{~mm}$ & $\mathrm{MG}$ & qtzites, qtz schists; lesser fel volcanics and intrusives, qtz & -85 & 3 & 2 & 10 \\
\hline 1380 & 1390 & GY & $\mathrm{BN}$ & $\overline{S A}$ & SR & $<9 \mathrm{~mm}$ & MG & qtzites, qtz schists; lesser fel intrusives, qtz & -94 & 3 & & $<3$ \\
\hline 1390 & 1400 & GY & $\overline{\mathrm{BN}}$ & $\overline{S A}$ & $\overline{\mathrm{SR}}$ & $<9 \mathrm{~mm}$ & MG & qtzites, qtz schists; lesser fel volcanics and intrusives, qtz & $\sim 89$ & 5 & 3 & 3 \\
\hline 1400 & 1410 & GY & $\mathrm{BN} / \mathrm{PK}$ & $\overline{S A}$ & $\overline{\mathrm{SR}}$ & $<10 \mathrm{~mm}$ & MG & qtzites, qtz schists, phyllites; minor fel volcanics and intrusives, qtz & $\sim 90$ & 5 & 2 & $<3$ \\
\hline 1410 & 1420 & GY & LT & SA & SR & $<12 \mathrm{~mm}$ & $\mathrm{MG}$ & qtzites, qtz schists, phyllites; minor fel volcanics and intrusives, qtz & -89 & 3 & 3 & 5 \\
\hline 1420 & 1430 & BG & GY & SA & SR & $<8 \mathrm{~mm}$ & FG & qtzites, qtz schists, phyllites; minor fel volcanics and intrusives, qtz & $\sim 85$ & 5 & 3 & 10 \\
\hline 1430 & 1440 & GY & PK & A/SA & $\overline{\mathrm{SR}}$ & $<8 \mathrm{~mm}$ & FG & $\sim 10 \%$ of bright green chips of siltstone (?); otherwise like above & $\sim 87$ & 3 & 10 & \\
\hline 1440 & 1450 & GY & $\overline{P K}$ & A/SA & $\overline{\mathrm{SR}}$ & $<6 \mathrm{~mm}$ & FG & $\sim 15 \%$ of multicoloured chips of siltstone (?); otherwise like above & $\sim 87$ & & 5 & 8 \\
\hline 1450 & 1460 & GY & $\mathrm{BG}$ & A/SA & $\overline{S R}$ & $<10 \mathrm{~mm}$ & MG & $\sim 15 \%$ of multicoloured chips of siltstone (?); otherwise like above & -92 & 3 & & 5 \\
\hline 1460 & 1470 & GY & BG & SA & SR & $<11 \mathrm{~mm}$ & MG & qtzites, qtz schists, phyllites; minor fel volcanics and intrusives, qtz & $\sim 84$ & 3 & 8 & 5 \\
\hline 1470 & 1480 & GY & $\mathrm{BG} / \mathrm{PK}$ & SA & $\mathrm{SR}$ & $<8 \mathrm{~mm}$ & FG & qtzites, qtz schists, phyllites; minor fel volcanics and intrusives, qtz & $\sim 73$ & 5 & 12 & 10 \\
\hline 1480 & 1490 & GY & BG & SA & SR & $<7 \mathrm{~mm}$ & FG & qtzites, qtz schists, phyllites; minor fel volcanics and intrusives, qtz & $\sim 78$ & 5 & 5 & 12 \\
\hline 1490 & 1500 & $\mathrm{BN}$ & GY & $\mathrm{SA}$ & SR & $<8 \mathrm{~mm}$ & FG & qtzites, qtz schists, phyllites; minor fel volcanics and intrusives, qtz & $\sim 75$ & 3 & 10 & $<5$ \\
\hline 1500 & 1510 & GY & $\mathrm{PK} / \mathrm{BN}$ & $\mathrm{SA}$ & $\mathrm{SR}$ & $<8 \mathrm{~mm}$ & FG & qtzites, qtz schists, phyllites; minor fel volcanics and intrusives, qtz & $\sim 70$ & 15 & 5 & 10 \\
\hline 1510 & 1520 & GY & $\mathrm{PK} / \mathrm{BN}$ & A/SA & $\overline{S R}$ & $<6 \mathrm{~mm}$ & FG & qtzites, qtz schists, phyllites; minor fel volcanics and intrusives, qtz & $\sim 72$ & $<5$ & 8 & 5 \\
\hline
\end{tabular}




\section{FAIRBANK}

PROJECT

HOLE NO.

LOCATION Pumpernickel Valley

\section{Mud Log}

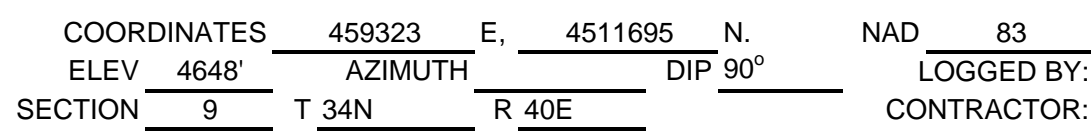

\section{LITHOLOGY DESCRIPTION / COMMENTS}

$\sim 5 \%$ of bright green to pinkish siltstone (?); otherwise like above

$-15 \%$ of bright green to pinkish red siltstone (?); otherwise like above

$-15 \%$ of bright green to pinkish red siltstone (?); otherwise like above

$\sim 20 \%$ of bright green to pinkish red siltstone (?); otherwise like above

$-25 \%$ of bright green to pinkish red siltstone (?); otherwise like above

$-25 \%$ of bright green to pinkish red siltstone (?); otherwise like above

$-12 \%$ of bright green to pinkish red siltstone (?); otherwise like above

$-12 \%$ of bright green to pinkish red siltstone (?); otherwise like above

\begin{tabular}{|c|c|c|c|c|c|c|c|c|c|c|c|c|}
\hline \multicolumn{2}{|c|}{ DEPTH (feet) } & \multicolumn{2}{|c|}{ COLOUR } & \multicolumn{2}{|c|}{ ROUNDNESS } & \multicolumn{2}{|c|}{ GRAIN SIZE } & \multirow{2}{*}{ LITHOLOGY DESCRIPTION / COMMENTS } & \multirow{2}{*}{$\begin{array}{l}\text { Meta- } \\
\text { Seds \% }\end{array}$} & \multirow{2}{*}{$\begin{array}{c}\text { Intrusive } \\
\%\end{array}$} & \multirow{2}{*}{$\begin{array}{c}\text { Volcanics } \\
\%\end{array}$} & \multirow[t]{2}{*}{ Qtz \% } \\
\hline From & To & 1 & 2 & Angular & Rounded & Range & Class & & & & & \\
\hline 1520 & 1530 & GY & $\mathrm{RD} / \mathrm{BN}$ & $\mathrm{A} / \mathrm{SA}$ & $\overline{\mathrm{SR}}$ & $<6 \mathrm{~mm}$ & $\mathrm{FG}$ & $-5 \%$ of bright green to pinkish siltstone (?); otherwise like above & -83 & 5 & 3 & $<3$ \\
\hline 1530 & 1540 & GY & $\mathrm{RD} / \mathrm{BN}$ & A/SA & SR & $<6 \mathrm{~mm}$ & FG & $\sim 15 \%$ of bright green to pinkish red siltstone (?); otherwise like above & -95 & & 5 & \\
\hline 1540 & 1550 & GY & RD/BN & $\mathrm{A} / \mathrm{SA}$ & $\overline{\mathrm{SR}}$ & $<6 \mathrm{~mm}$ & FG & $-15 \%$ of bright green to pinkish red siltstone (?); otherwise like above & -84 & 10 & 3 & 3 \\
\hline 1550 & 1560 & GY & $\mathrm{PK} / \mathrm{BN}$ & A & SR & $<8 \mathrm{~mm}$ & FG & $\sim 20 \%$ of bright green to pinkish red siltstone (?); otherwise like above & $\sim 97$ & & 3 & \\
\hline 1560 & 1570 & GY & $\mathrm{PK} / \mathrm{BN}$ & A & $\overline{\mathrm{SR}}$ & $<9 \mathrm{~mm}$ & MG & - 25\% of bright green to pinkish red siltstone (?); otherwise like above & $\sim 87$ & 5 & 3 & 5 \\
\hline 1570 & 1580 & GY & $\mathrm{PK} / \mathrm{BN}$ & A & SR & $<7 \mathrm{~mm}$ & FG & $\sim 25 \%$ of bright green to pinkish red siltstone (?); otherwise like above & $\sim 87$ & & 8 & 5 \\
\hline 1580 & 1590 & GY & $\mathrm{PK} / \mathrm{BN}$ & A & SR & $<7 \mathrm{~mm}$ & FG & $-12 \%$ of bright green to pinkish red siltstone (?); otherwise like above & $\sim 87$ & 3 & 5 & 5 \\
\hline 1590 & 1600 & GY & $\mathrm{PK} / \mathrm{BN}$ & A & SR/R & $<6 \mathrm{~mm}$ & FG & $\sim 12 \%$ of bright green to pinkish red siltstone (?); otherwise like above & $\sim 87$ & & 8 & 5 \\
\hline & & & & & & & & & & & & \\
\hline & & & & & & & & & & & & \\
\hline & & & & & & & & & & & & \\
\hline & & & & & & & & & & & & \\
\hline & & & & & & & & & & & & \\
\hline & & & & & & & & & & & & \\
\hline & & & & & & & & & & & & \\
\hline Abbrev & Color & & & Abbrev & Round & & & Abbreviation - rock/mineral type & & & & \\
\hline$\overline{B G}$ & Beige & & & VA & very & angular & & metaseds = metasediments & & & & \\
\hline$\overline{\mathrm{BL}}$ & Blue & & & A & angular & & & qtz = quartz & & & & \\
\hline $\mathrm{BN}$ & Brown & & & SA & sub- & angular & & qtz-fds-bio = quartz-feldspar-biotite & & & & \\
\hline$\overline{\mathrm{CH}}$ & Charcoa & & & $\overline{\mathrm{SR}}$ & sub- & rounded & & qtzites = quartzites & & & & \\
\hline GN & Green & & & $\mathrm{R}$ & rounded & & & fel $=$ felsic & & & & \\
\hline$\overline{\mathrm{GY}}$ & Gray & & & & & & & volcs $=$ volcanics & & & & \\
\hline$\overline{\mathrm{OL}}$ & Olive & & & & & & & sst = sandstones & & & & \\
\hline$\overline{\mathrm{PK}}$ & Pink & & & & & & & ox = Fe oxidized & & & & \\
\hline$\overline{P E}$ & Purple & & & & & & & adds $=$ additions & & & & \\
\hline $\mathrm{RD}$ & Red & & & & & & & & & & & \\
\hline $\mathrm{RY}$ & Rusty & & & & & & & & & & & \\
\hline $\begin{array}{l}L \\
\end{array}$ & Yellow & & & & & & & & & & & \\
\hline & & & & & & & & & & & & \\
\hline$\overline{\mathrm{DK}}$ & Dark & & & & & & & & & & & \\
\hline $\mathrm{LT}$ & Light & & & & & & & & & & & \\
\hline & & & & & & & & & & & & \\
\hline & & & & & & & & & & & & \\
\hline & & & & & & & & & & & & \\
\hline & & & & & & & & & & & & \\
\hline & & & & & & & & & & & & \\
\hline & & & & & & & & & & & & \\
\hline & & & & & & & & & & & & \\
\hline
\end{tabular}

PAGE: $\quad 5$ OF 5

DATE: $30.8-17.9,2005$

Adam Szybinski WDC 
Nevada Geothermal Power Inc. and Inovision Solutions Inc

Drill hole:

PVTG-4 


\section{$\square \frac{\text { FAIRBANK }}{\text { ENGINEERING LTD }}$ \\ PROJECT Pumpernickel Valley}

HOLE NO. PVTG-4

LOCATION Pumpernickel Vly, Humboldt Co.

\section{Mud Log}

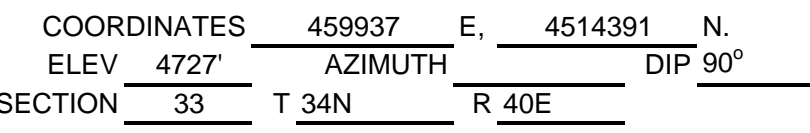

NAD

83

LOGGED BY:

CONTRACTOR:

PAGE:

1 OF 4

DATE: $12.9-17.9,2005$ Adam Szybinski WDC

\begin{tabular}{|c|c|c|c|c|c|c|c|c|c|c|c|c|}
\hline \multicolumn{2}{|c|}{ DEPTH (feet) } & \multicolumn{2}{|c|}{ COLOUR } & \multicolumn{2}{|c|}{ ROUNDNESS } & \multicolumn{2}{|c|}{ GRAIN SIZE } & \multirow{2}{*}{ LITHOLOGY DESCRIPTION / COMMENTS } & \multirow{2}{*}{$\begin{array}{l}\text { Meta- } \\
\text { Seds \% }\end{array}$} & \multirow{2}{*}{$\begin{array}{c}\text { Intr/Volcs } \\
\%\end{array}$} & \multirow{2}{*}{$\begin{array}{l}\text { Qtz } \\
\%\end{array}$} & \multirow{2}{*}{$\begin{array}{c}\mathrm{Fe} \text { ox } \\
\%\end{array}$} \\
\hline From & To & 1 & 2 & Angular & Rounded & Range & Class & & & & & \\
\hline 0 & 10 & BG & GY & A/SA & SR & $<35 \mathrm{~mm}$ & VCG & metaseds, Preble Fm. and Havallah: qtzites, mudstones, qtz schists & $\sim 100$ & & & \\
\hline 10 & 20 & GY & BG & A & SR & $<20 \mathrm{~mm}$ & CG & metaseds, Preble Fm. and Havallah: qtzites, mudstones, qtz schists & $\sim 100$ & & & \\
\hline 20 & 30 & GY & BG & SA & $\mathrm{SR}$ & $<20 \mathrm{~mm}$ & CG & metaseds, Preble Fm. and Havallah, like above; some qtz and Fe ox & $\sim 90$ & & 10 & $\sim 15$ \\
\hline 30 & 40 & BG & GY & SA & SR & $<38 \mathrm{~mm}$ & VCG & metaseds, Preble Fm. and Havallah, adds fel volcs and intrusives, qtz & -80 & 15 & 5 & $\sim 15$ \\
\hline 40 & 50 & BG & & SA & SR & $<40 \mathrm{~mm}$ & VCG & metaseds, Preble Fm. and Havallah, adds fel volcs and intrusives, qtz & $\sim 85$ & 10 & 5 & $\sim 5$ \\
\hline 50 & 60 & BG & GY & SA & SR & $<30 \mathrm{~mm}$ & CG & metaseds, Preble Fm. and Havallah, adds fel volcs and intrusives, qtz & $\sim 90$ & 5 & 5 & $\sim 10$ \\
\hline 60 & 70 & BG & GY & A/SA & SR & $<20 \mathrm{~mm}$ & CG & metaseds, Preble Fm. and Havallah, adds fel volcs and intrusives & $\sim 90$ & 10 & & \\
\hline 70 & 80 & BG & & SA & SR & $<25 \mathrm{~mm}$ & $\overline{C G}$ & metaseds, Preble Fm. and Havallah, adds fel volcs and intrusives, qtz & $\sim 88$ & 5 & 7 & $\sim 15$ \\
\hline 80 & 90 & GY & & SA & SR & $<20 \mathrm{~mm}$ & CG & metaseds, Preble Fm. and Havallah, adds fel volcs and intrusives, qtz & $\sim 90$ & 5 & 5 & $\sim 10$ \\
\hline 90 & 100 & BG & GY & SA & $\mathrm{R}$ & $<30 \mathrm{~mm}$ & CG & metaseds, Preble Fm. and Havallah, adds fel volcs and intrusives, qtz & $\sim 100$ & $<3$ & 10 & 3 \\
\hline 100 & 110 & BG & GY & SA & $\bar{R}$ & $<20 \mathrm{~mm}$ & $\overline{C G}$ & metaseds, Preble Fm. and Havallah, adds fel volcs and intrusives, qtz & $\sim 85$ & $>5$ & 10 & 5 \\
\hline 110 & 120 & BG & GY & SA & SR & $<18 \mathrm{~mm}$ & $\overline{C G}$ & metaseds, Preble Fm. and Havallah, adds fel volcs and intrusives, qtz & $\sim 82$ & 10 & 8 & $\sim 10$ \\
\hline 120 & 130 & GY & & SA & SR & $<28 \mathrm{~mm}$ & CG & metaseds, Preble Fm. and Havallah, adds fel volcs and intrusives, qtz & $\sim 85$ & 5 & 10 & $\sim 10$ \\
\hline 130 & 140 & GY & & $\overline{S A}$ & SR & $<16 \mathrm{~mm}$ & MG & metaseds, Preble Fm. and Havallah, adds fel volcs and intrusives, qtz & $\sim 80$ & 10 & 10 & $\sim 15$ \\
\hline 140 & 150 & BG & DK & $\mathrm{SA}$ & SR & $<22 \mathrm{~mm}$ & CG & metaseds, Preble Fm. and Havallah, adds fel volcs and intrusives, qtz & $\sim 75$ & 20 & 5 & 5 \\
\hline 150 & 160 & GY & & SA & $\overline{S R}$ & $<10 \mathrm{~mm}$ & MG & metaseds, Preble Fm. and Havallah, adds fel volcs and intrusives, qtz & $\sim 72$ & 20 & 8 & -5 \\
\hline 160 & 170 & BG & GY & & & $<2 \mathrm{~mm}$ & $\mathrm{~F}$ & poor sample & & & & \\
\hline 170 & 180 & GY & & $\overline{S A}$ & SR & $<31 \mathrm{~mm}$ & CG & metaseds, Preble Fm. and Havallah, adds fel volcs and intrusives, qtz & $\sim 90$ & 5 & 5 & $\sim 15$ \\
\hline 180 & 190 & GY & $\mathrm{BN}$ & $\overline{S A}$ & SR & $<46 \mathrm{~mm}$ & VCG & metaseds, Preble Fm. and Havallah, adds fel volcs and intrusives & $\sim 80$ & 10 & 10 & \\
\hline 190 & 200 & GY & LT & SA & SR & $<21 \mathrm{~mm}$ & CG & metaseds, Preble Fm. and Havallah, adds fel volcs and intrusives, qtz & $\sim 75$ & 10 & 15 & 8 \\
\hline 200 & 210 & GY & BG & $\overline{S A}$ & SR & $<12 \mathrm{~mm}$ & MG & metaseds, Preble Fm. and Havallah, adds fel volcs and intrusives, qtz & -82 & 8 & 10 & $\sim 5$ \\
\hline 210 & 220 & GY & $\mathrm{BN}$ & SA & $\mathrm{R}$ & $<17 \mathrm{~mm}$ & CG & metaseds, Preble Fm. and Havallah, adds fel volcs and intrusives, qtz & $\sim 82$ & 10 & 8 & -5 \\
\hline 220 & 230 & GY & $\mathrm{BN}$ & $\overline{\mathrm{SA}}$ & $\mathrm{R}$ & $<14 \mathrm{~mm}$ & MG & metaseds, Preble Fm. and Havallah, adds fel volcs and intrusives, qtz & $\sim 81$ & 7 & 12 & $\sim 5$ \\
\hline 230 & 240 & GY & $\mathrm{PK}$ & SA & $\mathrm{R}$ & $<15 \mathrm{~mm}$ & MG & metaseds, Preble Fm. and Havallah, adds fel volcs and intrusives, qtz & $\sim 92$ & 8 & 10 & $\sim 5$ \\
\hline 240 & 250 & GY & $\mathrm{PK}$ & $\overline{S A}$ & $\mathrm{R}$ & $<17 \mathrm{~mm}$ & CG & metaseds, Preble Fm. and Havallah, adds fel volcs and intrusives, qtz & $\sim 79$ & 6 & 15 & $\sim 5$ \\
\hline 250 & 260 & GY & $\mathrm{PK}$ & SA & SR & $<15 \mathrm{~mm}$ & MG & metaseds, Preble Fm. and Havallah, adds fel volcs and intrusives, qtz & $\sim 83$ & 5 & 15 & $\sim 5$ \\
\hline 260 & 270 & GY & $\mathrm{PK}$ & SA & $\mathrm{R}$ & $<13 \mathrm{~mm}$ & CG & metaseds, Preble Fm. and Havallah, adds fel volcs and intrusives, qtz & -85 & 5 & 10 & $\sim 5$ \\
\hline 270 & 280 & GY & $\mathrm{BN}$ & SA & $\mathrm{R}$ & $<22 \mathrm{~mm}$ & CG & metaseds, Preble Fm. and Havallah, adds fel volcs and intrusives, qtz & $\sim 92$ & 3 & 5 & 3 \\
\hline 280 & 290 & GY & $\mathrm{BN}$ & $\overline{S A}$ & SR & $<17 \mathrm{~mm}$ & MG & metaseds, Preble Fm. and Havallah, adds fel volcs and intrusives, qtz & -89 & 3 & 8 & 3 \\
\hline 290 & 300 & GY & $\mathrm{BN}$ & SA & $\mathrm{R}$ & $<20 \mathrm{~mm}$ & CG & metaseds, Edna Fm. and Havallah: adds fel volcs and intrusives, qtz & $\sim 90$ & 3 & 7 & 3 \\
\hline 300 & 310 & GY & $\mathrm{BN}$ & SA & $\mathrm{R}$ & $<22 \mathrm{~mm}$ & CG & metaseds, Edna Fm. and Havallah: adds fel volcs and intrusives, qtz & $\sim 87$ & 8 & 5 & \\
\hline 310 & 320 & $\mathrm{BN}$ & GY & $\mathrm{SA}$ & $\mathrm{R}$ & $<19 \mathrm{~mm}$ & CG & metaseds, Edna Fm. and Havallah: adds fel volcs and intrusives, qtz & $\sim 82$ & 10 & 8 & \\
\hline 320 & 330 & GY & $\mathrm{BN}$ & SA & SR & $<15 \mathrm{~mm}$ & MG & metaseds, Edna Fm. and Havallah: adds fel volcs and intrusives, qtz & $\sim 88$ & 5 & 7 & \\
\hline 330 & 340 & GY & $\mathrm{PK}$ & SA & SR & $<16 \mathrm{~mm}$ & MG & metaseds, Edna Fm. and Havallah: adds fel volcs and intrusives, qtz & $\sim 90$ & 4 & 6 & \\
\hline 340 & 350 & GY & BG & SA & SR & $<18 \mathrm{~mm}$ & CG & metaseds, Edna Fm. and Havallah: adds fel volcs and intrusives, qtz & $\sim 87$ & 3 & 10 & \\
\hline 350 & 360 & GY & BG & $\mathrm{SA}$ & SR & $<21 \mathrm{~mm}$ & FG & metaseds, Edna Fm. and Havallah: adds qtz & $\sim 93$ & & 7 & \\
\hline 360 & 370 & GY & BG & $\mathrm{SA}$ & $\mathrm{R}$ & $<18 \mathrm{~mm}$ & CG & metaseds, Edna Fm. and Havallah: adds fel volcs and intrusives, qtz & $\sim 73$ & 5 & 10 & \\
\hline 370 & 380 & GY & BG & SA & $\mathrm{SR}$ & $<16 \mathrm{~mm}$ & MG & metaseds, Edna Fm. and Havallah: adds fel volcs and intrusives, qtz & $\sim 87$ & 5 & 8 & \\
\hline
\end{tabular}




\section{FAIRBANK}

PROJECT Pumpernickel Valley

HOLE NO.

LOCATION Pumpernickel Vly, Humboldt Co.

\section{Mud Log}

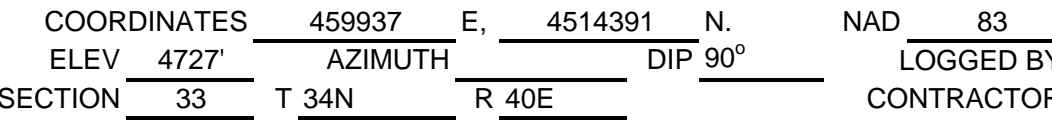

PAGE:

2 OF 4

DATE: 12.9-17.9, 2005 Adam Szybinski WDC

\begin{tabular}{|c|c|c|c|c|c|c|c|c|c|c|c|c|}
\hline \multicolumn{2}{|c|}{ DEPTH (feet) } & \multicolumn{2}{|c|}{ COLOUR } & \multicolumn{2}{|c|}{ ROUNDNESS } & \multicolumn{2}{|c|}{ GRAIN SIZE } & \multirow{2}{*}{ LITHOLOGY DESCRIPTION / COMMENTS } & \multirow{2}{*}{$\begin{array}{l}\text { Meta- } \\
\text { Seds \% }\end{array}$} & \multirow{2}{*}{$\begin{array}{c}\text { Intr/Volcs } \\
\%\end{array}$} & \multirow{2}{*}{$\begin{array}{l}\text { Qtz } \\
\%\end{array}$} & \multirow{2}{*}{$\begin{array}{c}\text { Fe ox } \\
\%\end{array}$} \\
\hline From & To & 1 & 2 & Angular & Rounded & Range & Class & & & & & \\
\hline 380 & 390 & GY & BG & SA & $\mathrm{SR}$ & $<23 \mathrm{~mm}$ & CG & metaseds, Edna Fm. and Havallah: adds fel volcs and intrusives, qtz & $\sim 87$ & 3 & 10 & \\
\hline 390 & 400 & GY & & $\overline{S A}$ & SR & $<22 \mathrm{~mm}$ & CG & metaseds, Edna Fm. and Havallah: adds fel volcs and intrusives, qtz & $\sim 89$ & 3 & 8 & \\
\hline 400 & 410 & GY & GN & $\mathrm{SA}$ & $\mathrm{SR}$ & $<21 \mathrm{~mm}$ & CG & metaseds, Edna Fm. and Havallah: adds fel volcs and intrusives, qtz & $\sim 93$ & 1 & 6 & \\
\hline 410 & 420 & GY & BG & $\overline{S A}$ & SR & $<25 \mathrm{~mm}$ & CG & metaseds, Edna Fm. and Havallah: adds fel volcs and intrusives, qtz & $\sim 94$ & 1 & 5 & \\
\hline 420 & 430 & GY & BG & $\overline{S A}$ & SR & $<20 \mathrm{~mm}$ & CG & metaseds, Edna Fm. and Havallah: adds fel volcs and intrusives, qtz & 90 & 2 & 8 & \\
\hline 430 & 440 & GY & & $\overline{\mathrm{SA}}$ & SR & $<28 \mathrm{~mm}$ & CG & metaseds, Edna Fm. and Havallah: adds qtz & -95 & & 5 & \\
\hline 440 & 450 & GY & BG & $\overline{S A}$ & $\overline{S R}$ & $<17 \mathrm{~mm}$ & CG & metaseds, Edna Fm. and Havallah & $\sim 100$ & & & \\
\hline 450 & 460 & GY & $\mathrm{BG}$ & $\bar{A}$ & $\overline{\mathrm{SR}}$ & $<22 \mathrm{~mm}$ & CG & metaseds, Edna Fm. and Havallah: adds qtz & -95 & & 5 & \\
\hline 460 & 470 & GY & BG & $\overline{\mathrm{SA}}$ & & $<16 \mathrm{~mm}$ & MG & metaseds, Edna Fm. and Havallah: adds fel volcs and intrusives, qtz & $\sim 90$ & 2 & 8 & \\
\hline 470 & 480 & BG & $\mathrm{OL}$ & $\mathrm{SA}$ & & $<13 \mathrm{~mm}$ & MG & metaseds, Edna Fm. and Havallah: adds qtz & -85 & & 15 & \\
\hline 480 & 490 & GY & BG & $\overline{\mathrm{SA}}$ & SR & $<13 \mathrm{~mm}$ & MG & metaseds, Edna Fm. and Havallah: adds fel volcs and intrusives, qtz & $\sim 88$ & 2 & 10 & \\
\hline 490 & 500 & GY & $\mathrm{OL}$ & $\mathrm{SA}$ & SR & $<15 \mathrm{~mm}$ & MG & metaseds, Edna Fm. and Havallah: adds qtz & $\sim 90$ & & 10 & \\
\hline 500 & 510 & GY & BG & $\overline{S A}$ & SR & $<5 \mathrm{~mm}$ & FG & metaseds, Edna Fm. and Havallah: adds fel volcs and intrusives, qtz & $\sim 87$ & 5 & 8 & \\
\hline 510 & 520 & GY & $\overline{\mathrm{OL}}$ & $\overline{\mathrm{SA}}$ & SR & $<8 \mathrm{~mm}$ & FG & metaseds, Edna Fm. and Havallah: adds fel volcs and intrusives, qtz & $\sim 72$ & 20 & 8 & \\
\hline 520 & 530 & GY & $\mathrm{OL}$ & $\mathrm{SA}$ & SR & $<15 \mathrm{~mm}$ & MG & metaseds, Edna Fm. and Havallah: adds qtz & $\sim 90$ & & 10 & \\
\hline 530 & 540 & GY & $\mathrm{PK}$ & $\mathrm{SA}$ & SR & $<8 \mathrm{~mm}$ & FG & metaseds, Edna Fm. and Havallah: adds fel volcs and intrusives, qtz & $\sim 70$ & 20 & 10 & \\
\hline 540 & 550 & GY & $\mathrm{OL}$ & $\mathrm{SA}$ & SR & $<13 \mathrm{~mm}$ & MG & metaseds, Edna Fm. and Havallah: adds fel volcs and intrusives, qtz & $\sim 85$ & 5 & 10 & \\
\hline 550 & 560 & GY & $\overline{\mathrm{OL}}$ & $\mathrm{SA}$ & SR & $<8 \mathrm{~mm}$ & FG & metaseds, Edna Fm. and Havallah: adds fel volcs and intrusives, qtz & $\sim 77$ & 8 & 15 & \\
\hline 560 & 570 & GY & & $\mathrm{SA}$ & SR & $<11 \mathrm{~mm}$ & MG & metaseds, Edna Fm. and Havallah: adds fel volcs and intrusives, qtz & $\sim 80$ & 10 & 10 & \\
\hline 570 & 580 & GY & $\mathrm{OL}$ & $\mathrm{SA}$ & & $<13 \mathrm{~mm}$ & MG & metaseds, Edna Fm. and Havallah: adds fel volcs and intrusives, qtz & $\sim 85$ & 5 & 12 & \\
\hline 580 & 590 & GY & $\mathrm{OL}$ & SA & & $<11 \mathrm{~mm}$ & MG & metaseds, Edna Fm. and Havallah: adds fel volcs and intrusives, qtz & $\sim 87$ & 5 & 8 & \\
\hline 590 & 600 & GY & $\mathrm{OL}$ & $\mathrm{SA}$ & SR & $<7 \mathrm{~mm}$ & FG & metaseds, Edna Fm. and Havallah: adds fel volcs and intrusives, qtz & $\sim 87$ & 3 & 10 & \\
\hline 600 & 610 & GY & $\mathrm{OL}$ & SA & SR & $<6 \mathrm{~mm}$ & FG & metaseds, Edna Fm. and Havallah: adds fel volcs and intrusives & -95 & 5 & & \\
\hline 610 & 620 & GY & & $\overline{\mathrm{SA}}$ & & $<6 \mathrm{~mm}$ & FG & metaseds, Edna Fm. and Havallah: adds fel volcs and intrusives, qtz & $\sim 80$ & 2 & 18 & \\
\hline 620 & 630 & GY & $\mathrm{OL}$ & SA & & $<7 \mathrm{~mm}$ & FG & metaseds, Edna Fm. and Havallah: adds fel volcs and intrusives, qtz & $\sim 84$ & 1 & 15 & \\
\hline 630 & 640 & GY & BG & SA & SR & $<10 \mathrm{~mm}$ & MG & metaseds, Edna Fm. and Havallah & $\sim 100$ & & & \\
\hline 640 & 650 & GY & BG & SA & & $<13 \mathrm{~mm}$ & chips & chert blocks, Edna Fm. or Havallah sequence & -90 & & 10 & \\
\hline 650 & 660 & GY & BG & A & $\mathrm{SR}$ & $<20 \mathrm{~mm}$ & chips & chert blocks, Edna Fm. or Havallah sequence & $\sim 87$ & 3 & 10 & 15 \\
\hline Bedrock & & & & & & & & & Qtzite\% & Chert\% & Qtz \% & Fe ox\% \\
\hline 660 & 670 & BG & $\mathrm{RY}$ & A/SA & & $<10 \mathrm{~mm}$ & chips & cherts, ox qtzites, qtz sst, Edna Fm. or Havallah & $\sim 60$ & $\sim 40$ & & $\sim 60$ \\
\hline 670 & 680 & $\mathrm{BN}$ & & A/SA & & $<8 \mathrm{~mm}$ & chips & cherts, ox qtzites, qtz sst, Edna Fm. or Havallah & $\sim 15$ & $\sim 50$ & & $\sim 15$ \\
\hline 680 & 690 & $\mathrm{BN}$ & & A/SA & & $<10 \mathrm{~mm}$ & chips & cherts, ox qtzites, qtz sst, Edna Fm. or Havallah & -30 & $\sim 60$ & & -30 \\
\hline 690 & 700 & $\mathrm{BN}$ & GY & $\mathrm{A} / \mathrm{SA}$ & & $<12 \mathrm{~mm}$ & chips & cherts, ox qtzites, qtz sst, Edna Fm. or Havallah & $\sim 30$ & $\sim 60$ & 5 & -30 \\
\hline 700 & 710 & $\mathrm{BN}$ & & A & SR & $<14 \mathrm{~mm}$ & chips & cherts, ox qtzites, qtz sst, Edna Fm. or Havallah & $\sim 42$ & 50 & 8 & $\sim 40$ \\
\hline 710 & 720 & $\mathrm{BN}$ & & A & SR & $<10 \mathrm{~mm}$ & chips & cherts, ox qtzites, qtz sst, Edna Fm. or Havallah & $\sim 51$ & 45 & 4 & $\sim 40$ \\
\hline 720 & 730 & BG & $\mathrm{RY}$ & $\mathrm{A} / \mathrm{SA}$ & & $<16 \mathrm{~mm}$ & chips & ox qtzites, qtz sst and cherts, Edna Fm. & $\sim 87$ & 8 & 5 & $\sim 80$ \\
\hline 730 & 740 & GY & $\mathrm{RY}$ & $\mathrm{A} / \mathrm{SA}$ & & $<15 \mathrm{~mm}$ & chips & ox qtzites, qtz sst and cherts, Edna Fm. & $\sim 92$ & 5 & 3 & $\sim 60$ \\
\hline 740 & 750 & BG & $\mathrm{RY}$ & $\mathrm{A} / \mathrm{SA}$ & & $<10 \mathrm{~mm}$ & chips & ox qtzites, qtz sst and cherts, Edna Fm. & $\sim 92$ & 5 & 3 & $\sim 70$ \\
\hline
\end{tabular}




\section{FAIRBANK}

PVTG-4

LOCATION Pumpernickel Vly, Humboldt Co.

\section{Mud Log}
COORDINATES
459937
E, $\frac{4514391}{\operatorname{DIP}} \mathrm{N}$.
NAD
83
ELEV 4727' AZIMUTH SECTION $\frac{33}{3}$ T34N R $40 \mathrm{~N}$ CONTRACTOR:

PAGE:

3 OF 4

\begin{tabular}{|c|c|c|c|c|c|c|c|c|c|c|c|c|}
\hline \multicolumn{2}{|c|}{ DEPTH (feet) } & \multicolumn{2}{|c|}{ COLOUR } & \multicolumn{2}{|c|}{ ROUNDNESS } & \multicolumn{2}{|c|}{ GRAIN SIZE } & \multirow{2}{*}{ LITHOLOGY DESCRIPTION / COMMENTS } & \multirow{2}{*}{$\begin{array}{c}\text { Qtzites } \\
\%\end{array}$} & \multirow{2}{*}{$\begin{array}{c}\text { Chert } \\
\%\end{array}$} & \multirow{2}{*}{$\begin{array}{l}\text { Qtz } \\
\%\end{array}$} & \multirow{2}{*}{$\begin{array}{c}\mathrm{Fe} \text { ox } \\
\%\end{array}$} \\
\hline From & To & 1 & 2 & Angular & Rounded & Range & Class & & & & & \\
\hline 750 & 760 & GY & BG & A/SA & & $<12 \mathrm{~mm}$ & chips & ox qtzites and qtz ssts, Edna Fm. & $\sim 100$ & & & $\sim 50$ \\
\hline 760 & 770 & GY & BG & $\mathrm{A} / \mathrm{SA}$ & & $<14 \mathrm{~mm}$ & chips & ox qtzites and qtz ssts, Edna Fm., adds qtz & $\sim 98$ & & 2 & $\sim 50$ \\
\hline 770 & 780 & BG & RY & A/SA & & $<10 \mathrm{~mm}$ & chips & ox qtzites and qtz ssts, Edna Fm., adds qtz & $\sim 95$ & & 5 & $\sim 60$ \\
\hline 780 & 790 & RY & & A/SA & & $<10 \mathrm{~mm}$ & chips & ox qtzites and qtz ssts, Edna Fm., adds qtz & $\sim 97$ & & 3 & $\sim 70$ \\
\hline 790 & 800 & GY & RY & A/SA & & $<9 \mathrm{~mm}$ & chips & ox qtzites and qtz ssts, Edna Fm., adds qtz & -97 & & 3 & $\sim 65$ \\
\hline 800 & 810 & GY & RY & $\mathrm{A} / \mathrm{SA}$ & & $<13 \mathrm{~mm}$ & chips & ox qtzites and qtz ssts, Edna Fm., adds qtz & $\sim 95$ & & 5 & $\sim 65$ \\
\hline 810 & 820 & GY & $\mathrm{OL}$ & A/SA & & $<12 \mathrm{~mm}$ & chips & ox qtzites and qtz ssts, Edna Fm., adds qtz & -95 & & 5 & -30 \\
\hline 820 & 830 & GY & $\mathrm{OL}$ & $\mathrm{A} / \mathrm{SA}$ & & $<12 \mathrm{~mm}$ & chips & ox qtzites and qtz ssts, Edna Fm., adds qtz & $\sim 95$ & & 5 & $\sim 20$ \\
\hline 830 & 840 & $\mathrm{OL}$ & RY & VA/SA & & $<10 \mathrm{~mm}$ & chips & ox qtzites and qtz ssts, Edna Fm., adds qtz & $\sim 97$ & & 3 & $\sim 10$ \\
\hline 840 & 850 & GY & $\mathrm{PE}$ & VA/SA & & $<9 \mathrm{~mm}$ & chips & argillite, jasper, adds chert and qtz (Edna Fm.?) & & & 8 & \\
\hline 850 & 860 & GY & $\mathrm{PE}$ & VA/SA & & $<7 \mathrm{~mm}$ & chips & argillite, jasper, adds chert and qtz (Edna Fm.?) & & & 10 & \\
\hline 860 & 870 & $\mathrm{PE}$ & $\mathrm{OL}$ & VA/SA & & $<6 \mathrm{~mm}$ & chips & argillite, siltst, some chert (Edna Fm.?), adds qtz & & $\sim 10$ & $\sim 10$ & \\
\hline 870 & 880 & GY & LT & $\mathrm{VA} / \mathrm{A}$ & & $<6 \mathrm{~mm}$ & chips & chert, opaline Si, siliceous siltsts (Edna Fm.?) & & $\sim 75$ & & \\
\hline 880 & 890 & GY & $\mathrm{OL}$ & VA/A & & $<6 \mathrm{~mm}$ & chips & chert, opaline Si, siliceous siltsts (Edna Fm.?) & & $\sim 75$ & & \\
\hline 890 & 900 & GY & OL & $\mathrm{VA} / \mathrm{A}$ & & $<6 \mathrm{~mm}$ & chips & chert, opaline Si, siliceous siltsts (Edna Fm.?), adds qtz & & $\sim 45$ & 2 & \\
\hline 900 & 910 & GY & $\mathrm{OL}$ & VA/A & & $<7 \mathrm{~mm}$ & chips & chert, opaline Si, siliceous siltsts (Edna Fm.?) & & $\sim 80$ & & \\
\hline 910 & 920 & GY & $\mathrm{OL}$ & $\mathrm{VA} / \mathrm{A}$ & & $<8 \mathrm{~mm}$ & chips & chert, opaline Si, siliceous siltsts (Edna Fm.?) & & $\sim 90$ & & \\
\hline 920 & 930 & GY & $\mathrm{OL}$ & VA/A & & $<8 \mathrm{~mm}$ & chips & chert, opaline Si, siliceous siltsts (Edna Fm.?) & & $\sim 85$ & & \\
\hline 930 & 940 & GY & $\mathrm{CH}$ & $\mathrm{VA} / \mathrm{A}$ & & $<6 \mathrm{~mm}$ & chips & chert, opaline Si, siliceous siltsts (Edna Fm.?) & & $\sim 10$ & & \\
\hline 940 & 950 & GY & RY & VA/A & & $<6 \mathrm{~mm}$ & chips & ox siltsts and fine qtzites, some cherts, Edna Fm. & & 5 & & $\sim 50$ \\
\hline 950 & 960 & GY & $\mathrm{RY}$ & $\mathrm{VA} / \mathrm{A}$ & & $<5 \mathrm{~mm}$ & chips & ox siltsts and fine qtzites, some cherts, Edna Fm. & & $\sim 15$ & 2 & $\sim 45$ \\
\hline 960 & 970 & GY & $\mathrm{RY}$ & VA/A & & $<6 \mathrm{~mm}$ & chips & ox siltsts and fine qtzites, some cherts, Edna Fm. & & $\sim 12$ & 5 & $\sim 45$ \\
\hline 970 & 980 & GY & $\mathrm{OL}$ & VA/A & & $<6 \mathrm{~mm}$ & chips & chert, opaline Si, siliceous siltsts (Edna Fm.?) & & $\sim 50$ & & $\sim 10$ \\
\hline 980 & 990 & GY & $\mathrm{BN}$ & $\mathrm{VA} / \mathrm{A}$ & & $<5 \mathrm{~mm}$ & chips & ox siltsts and qtzites, Edna Fm. & & 5 & 5 & -30 \\
\hline 990 & 1000 & GY & $\mathrm{BN}$ & VA/A & & $<6 \mathrm{~mm}$ & chips & ox ssts and qtzites, cherts, and mudst chips, Edna Fm. & & $\sim 15$ & 5 & $\sim 10$ \\
\hline 1000 & 1010 & GY & BG & VA/A & & $<7 \mathrm{~mm}$ & chips & partly ox ssts and qtzites, adds cherts, mudstone chips; Edna Fm. & & $\sim 15$ & 10 & $\sim 25$ \\
\hline 1010 & 1020 & GY & BG & $\mathrm{VA} / \mathrm{A}$ & & $<6 \mathrm{~mm}$ & chips & partly ox ssts and qtzites, adds cherts, mudstone chips; Edna Fm. & & 5 & 5 & $\sim 45$ \\
\hline 1020 & 1030 & $\mathrm{BN}$ & RY & $\mathrm{VA} / \mathrm{A}$ & & $<8 \mathrm{~mm}$ & chips & mainly ox ssts and qtzites, adds cherts, mudstone chips; Edna Fm. & & 5 & 4 & $\sim 70$ \\
\hline 1030 & 1040 & GY & RY & $\mathrm{VA} / \mathrm{A}$ & & $<6 \mathrm{~mm}$ & chips & partly ox ssts and qtzites, adds cherts, mudstone chips; Edna Fm. & & $<5$ & 3 & $\sim 35$ \\
\hline 1040 & 1050 & GY & $\mathrm{BG}$ & $\mathrm{VA} / \mathrm{A}$ & & $<6 \mathrm{~mm}$ & chips & mainly cherty mudstones, adds ox ssts and qtzites, cherts; Edna Fm.? & & $\sim 5$ & $<2$ & $\sim 15$ \\
\hline 1050 & 1060 & GY & BG & VA/A & & $<7 \mathrm{~mm}$ & chips & mainly cherty mudstones, adds ox ssts and qtzites; Edna Fm. & & & 4 & -5 \\
\hline 1060 & 1070 & GY & LT & $\mathrm{VA} / \mathrm{A}$ & & $<8 \mathrm{~mm}$ & chips & mainly cherts, adds opaline silica, siliceous siltstones (Edna Fm.?) & & $\sim 60$ & & $<5$ \\
\hline 1070 & 1080 & GY & LT & $\mathrm{VA} / \mathrm{A}$ & & $<6 \mathrm{~mm}$ & chips & mainly cherts, adds opaline silica, siliceous siltstones (Edna Fm.?) & & $\sim 70$ & & \\
\hline 1080 & 1090 & GY & & VA/SR & & $<10 \mathrm{~mm}$ & chips & mainly cherts, adds opaline silica, siliceous siltstones (Edna Fm.?) & & -35 & & \\
\hline 1090 & 1100 & GY & LT & VA/A & & $<12 \mathrm{~mm}$ & chips & mainly cherts, adds opaline silica, siliceous siltstones (Edna Fm.?) & & $\sim 70$ & & $\sim 10$ \\
\hline 1100 & 1110 & GY & $\mathrm{BN}$ & $\mathrm{VA} / \mathrm{A}$ & & $<8 \mathrm{~mm}$ & chips & partly ox ssts and qtzites, adds cherts; Edna Fm. & & 5 & 5 & $\sim 50$ \\
\hline 1110 & 1120 & GY & $\mathrm{BN}$ & $\mathrm{VA} / \mathrm{A}$ & & $<7 \mathrm{~mm}$ & chips & partly ox ssts and qtzites, adds cherts, mudstone chips; Edna Fm. & & $<5$ & 8 & \\
\hline 1120 & 1130 & GY & $\mathrm{BG}$ & $\mathrm{VA} / \mathrm{A}$ & & $<5 \mathrm{~mm}$ & chips & oxidized sandstones and quartzites mixed with cherts: Edna Fm. & & -30 & & \\
\hline
\end{tabular}




\section{FAIRBANK}

PROJECT

PVTG-4

LOCATION Pumpernickel Vly, Humboldt Co.

\section{Mud Log}

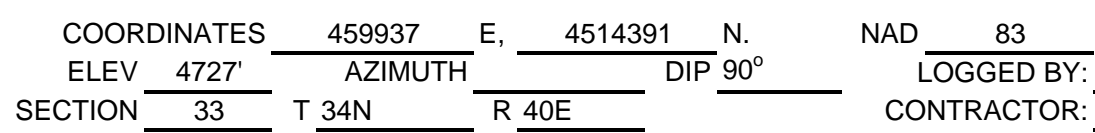

PAGE:

3 OF 4

DATE: 12.9-17.9, 2005 Adam Szybinski WDC

\begin{tabular}{|c|c|c|c|c|c|c|c|c|c|c|c|c|}
\hline \multicolumn{2}{|c|}{ DEPTH (feet) } & \multicolumn{2}{|c|}{ COLOUR } & \multicolumn{2}{|c|}{ ROUNDNESS } & \multicolumn{2}{|c|}{ GRAIN SIZE } & \multirow{2}{*}{ LITHOLOGY DESCRIPTION / COMMENTS } & \multirow{2}{*}{$\begin{array}{c}\text { Qtzites } \\
\% \\
\end{array}$} & \multirow{2}{*}{$\begin{array}{c}\text { Chert } \\
\%\end{array}$} & \multirow{2}{*}{$\begin{array}{c}\text { Qtz } \\
\%\end{array}$} & \multirow{2}{*}{$\begin{array}{c}\mathrm{Fe} \text { ox } \\
\%\end{array}$} \\
\hline From & To & 1 & 2 & Angular & Rounded & Range & Class & & & & & \\
\hline 1130 & 1140 & GY & BG & A/SA & & $<6 \mathrm{~mm}$ & chips & ox ssts and qtzites mixed with cherts: Edna Fm. & -80 & 10 & 10 & \\
\hline 1140 & 1150 & $\mathrm{BG}$ & GY & A/SA & & $<6 \mathrm{~mm}$ & chips & ox ssts and qtzites mixed with cherts: Edna Fm. & & & & \\
\hline 1150 & 1160 & GY & $\mathrm{BN}$ & $\mathrm{A} / \mathrm{SA}$ & & $<7 \mathrm{~mm}$ & chips & ox ssts and qtzites mixed with cherts: Edna Fm. & & & & \\
\hline 1160 & 1170 & GY & $\mathrm{BN}$ & $\mathrm{A} / \mathrm{SA}$ & & $<7 \mathrm{~mm}$ & chips & ox ssts and qtzites mixed with cherts: Edna Fm. & & & & \\
\hline & & & & & & & & & & & & \\
\hline & & & & & & & & & & & & \\
\hline & & & & & & & & & & & & \\
\hline & & & & & & & & & & & & \\
\hline & & & & & & & & & & & & \\
\hline Abbrev & Color & & & Abbrev & Round & & & Abbreviation - rock/mineral type & & & & \\
\hline$B G$ & Beige & & & VA & very & angular & & metaseds $=$ metasediments & & & & \\
\hline $\mathrm{BL}$ & Blue & & & $\mathrm{A}$ & angular & & & $q t z=$ quartz & & & & \\
\hline$\overline{B N}$ & Brown & & & $\overline{\mathrm{SA}}$ & sub- & angular & & qtz-fds-bio = quartz-feldspar-biotite & & & & \\
\hline $\mathrm{CH}$ & Charcoa & & & $\mathrm{SR}$ & sub- & rounded & & qtzites = quartzites & & & & \\
\hline GN & Green & & & $\mathrm{R}$ & rounded & & & fel $=$ felsic & & & & \\
\hline GY & Gray & & & & & & & volcs $=$ volcanics & & & & \\
\hline $\mathrm{OL}$ & Olive & & & & & & & sst = sandstones & & & & \\
\hline $\mathrm{PK}$ & Pink & & & & & & & ox = Fe oxidized & & & & \\
\hline $\mathrm{PE}$ & Purple & & & & & & & adds $=$ additions & & & & \\
\hline $\mathrm{RD}$ & Red & & & & & & & & & & & \\
\hline $\mathrm{RY}$ & Rusty & & & & & & & & & & & \\
\hline \begin{tabular}{|l}
$\mathrm{YL}$ \\
\end{tabular} & Yellow & & & & & & & & & & & \\
\hline & & & & & & & & & & & & \\
\hline DK & Dark & & & & & & & & & & & \\
\hline LT & Light & & & & & & & & & & & \\
\hline & & & & & & & & & & & & \\
\hline
\end{tabular}




\section{Appendix C}

Geochemical data and diagrams for water samples collected within and near the project area; analyzed by Thermochem Inc. 


\begin{tabular}{|c|c|c|c|c|c|c|c|c|c|c|c|c|c|c|c|c|}
\hline $\begin{array}{c}\text { Sample } \\
\text { Label }\end{array}$ & $\begin{array}{c}\text { Temp } \\
{ }^{\circ} \mathrm{C}\end{array}$ & $\mathrm{pH}$ & Li & $\mathrm{Na}$ & $\mathrm{K}$ & $\mathrm{Ca}$ & $\mathrm{Mg}$ & $\mathrm{SiO} 2$ & B & $\mathrm{Cl}$ & SO4 & $\mathrm{HCO} 3$ & $\mathrm{NH} 4$ & $\begin{array}{c}\text { sum } \\
\text { cations }\end{array}$ & $\begin{array}{c}\text { sum } \\
\text { anions }\end{array}$ & Balance \\
\hline BB2 & 20.3 & 8.07 & -0.20 & 48.0 & 3.16 & 62.6 & 14.0 & 30.1 & 0.166 & 58.6 & 56.9 & 215 & -0.255 & 6.47 & 6.36 & $2 \%$ \\
\hline BB4 & 22.8 & 8.22 & -0.20 & 63.8 & 3.64 & 70.4 & 14.5 & 32.1 & 0.302 & 64.2 & 93.6 & 221 & -0.255 & 7.60 & 7.38 & $3 \%$ \\
\hline $\mathrm{MDH}$ & 94.5 & 7.84 & 1.09 & 204 & 17.5 & 20.3 & 1.57 & 154 & 2.53 & 37.9 & 130 & 381 & -0.255 & 10.62 & 10.02 & $6 \%$ \\
\hline PVS-2 & 16.1 & 7.98 & -0.20 & 74.0 & 3.44 & 66.9 & 18.7 & 25.8 & 0.230 & 66.8 & 131 & 212 & -0.255 & 8.21 & 8.09 & $2 \%$ \\
\hline PVS-4 & 12.0 & 7.72 & -0.20 & 46.7 & 5.04 & 115 & 19.2 & 17.9 & -0.18 & 62.2 & 185 & 241 & -0.255 & 9.51 & 9.56 & $-1 \%$ \\
\hline PVS-5 & 22.5 & 8.01 & -0.20 & 43.0 & 5.15 & 19.9 & 5.81 & 40.3 & 0.179 & 28.1 & 17.5 & 133 & -0.255 & 3.50 & 3.34 & $5 \%$ \\
\hline TRS-1 & 68.0 & 7.82 & 1.15 & 210 & 17.8 & 6.88 & 0.529 & 144 & 2.59 & 39.0 & 141 & 373 & -0.255 & 10.14 & 10.15 & $0 \%$ \\
\hline TRS-5 & 15.5 & 7.81 & -0.20 & 72.8 & 6.37 & 213 & 46.7 & 30.8 & 0.205 & 88.5 & 507 & 270 & -0.255 & 17.83 & 17.48 & $2.0 \%$ \\
\hline TRS- 6 & 49.0 & 7.59 & 1.11 & 202 & 20.3 & 33.9 & 4.84 & 88.4 & 2.70 & 39.1 & 195 & 383 & -0.255 & 11.56 & 11.44 & $1.0 \%$ \\
\hline PV TG-1 & 25.0 & 7.92 & 0.24 & 144 & 10 & 89 & 18.7 & 25.1 & 0.83 & 153 & 270 & 189 & -0.511 & 12.54 & 13.05 & $-3.9 \%$ \\
\hline PV TG-2 & 12.0 & 7.9 & -0.10 & 60 & 9 & 103 & 18.7 & 27.0 & 0.19 & 65 & 211 & 189 & -0.511 & 9.57 & 9.33 & $3 \%$ \\
\hline PV TG-3 & 15.0 & 7.9 & 0.82 & 265 & 5 & 55 & 13.4 & 21.7 & 2.05 & 89 & 218 & 541 & -0.511 & 15.62 & 15.91 & $-2 \%$ \\
\hline PV TG-4 & 21.0 & 7.95 & 0.12 & 136 & 10 & 22 & 2.5 & 15.7 & 0.19 & 76 & 92 & 201 & -0.511 & 7.51 & 7.37 & $1.9 \%$ \\
\hline
\end{tabular}


Diagrams: Tclb and Tchs
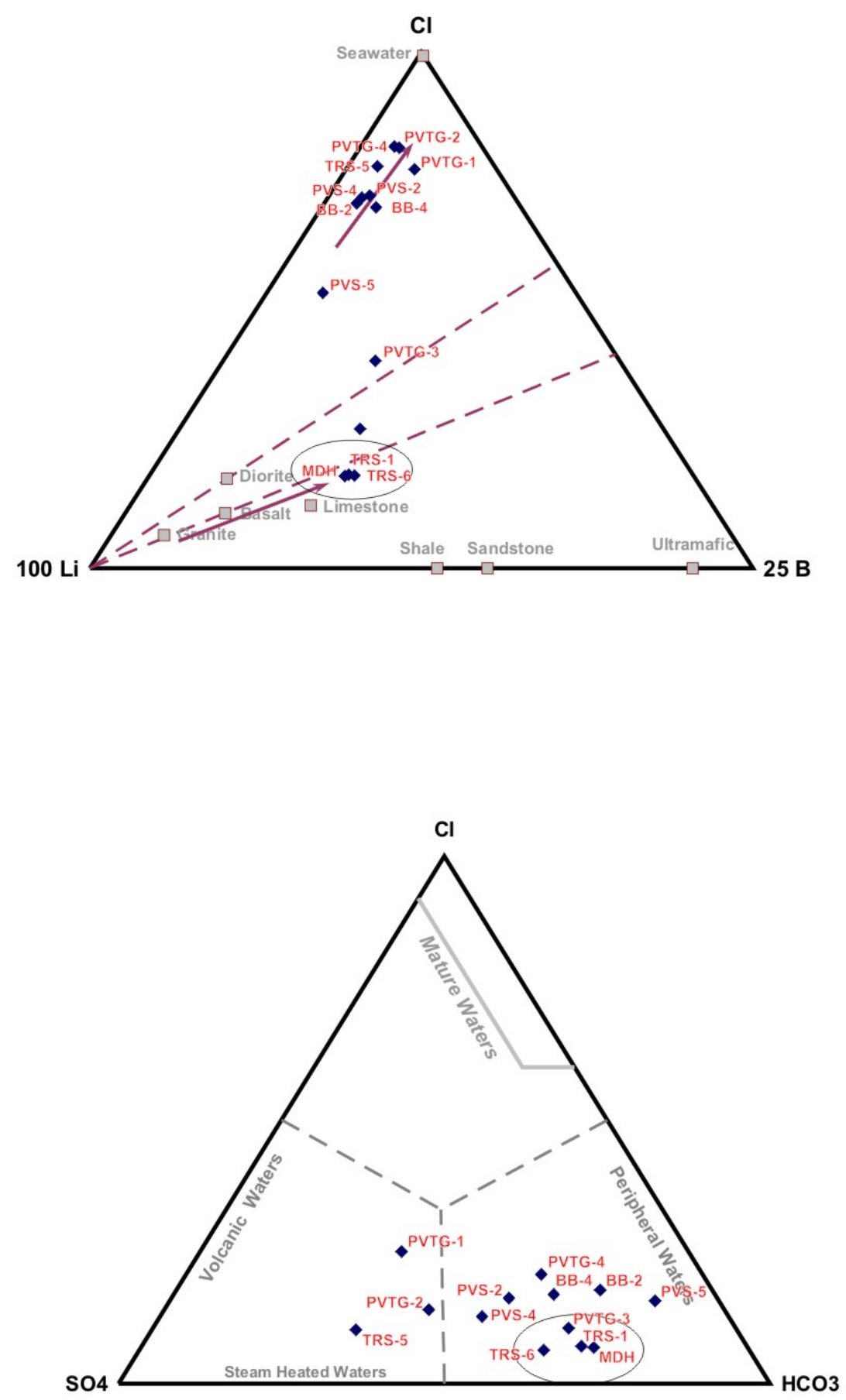

Fairbank Engineering Ltd. 


\section{Diagrams: Tnkm and Xmckn}
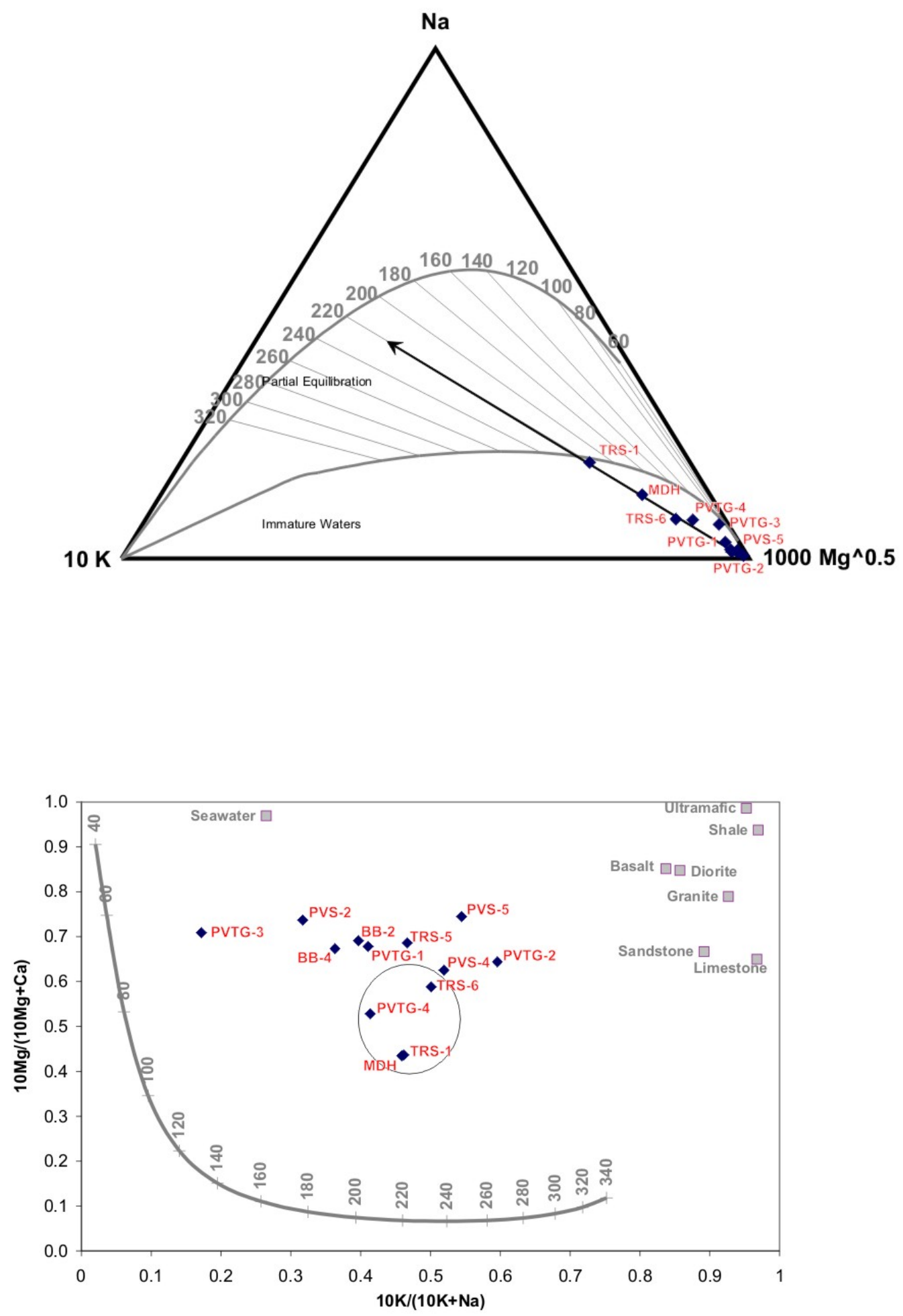

Fairbank Engineering Ltd. 


\section{Diagrams: Xkmc and Xkms}
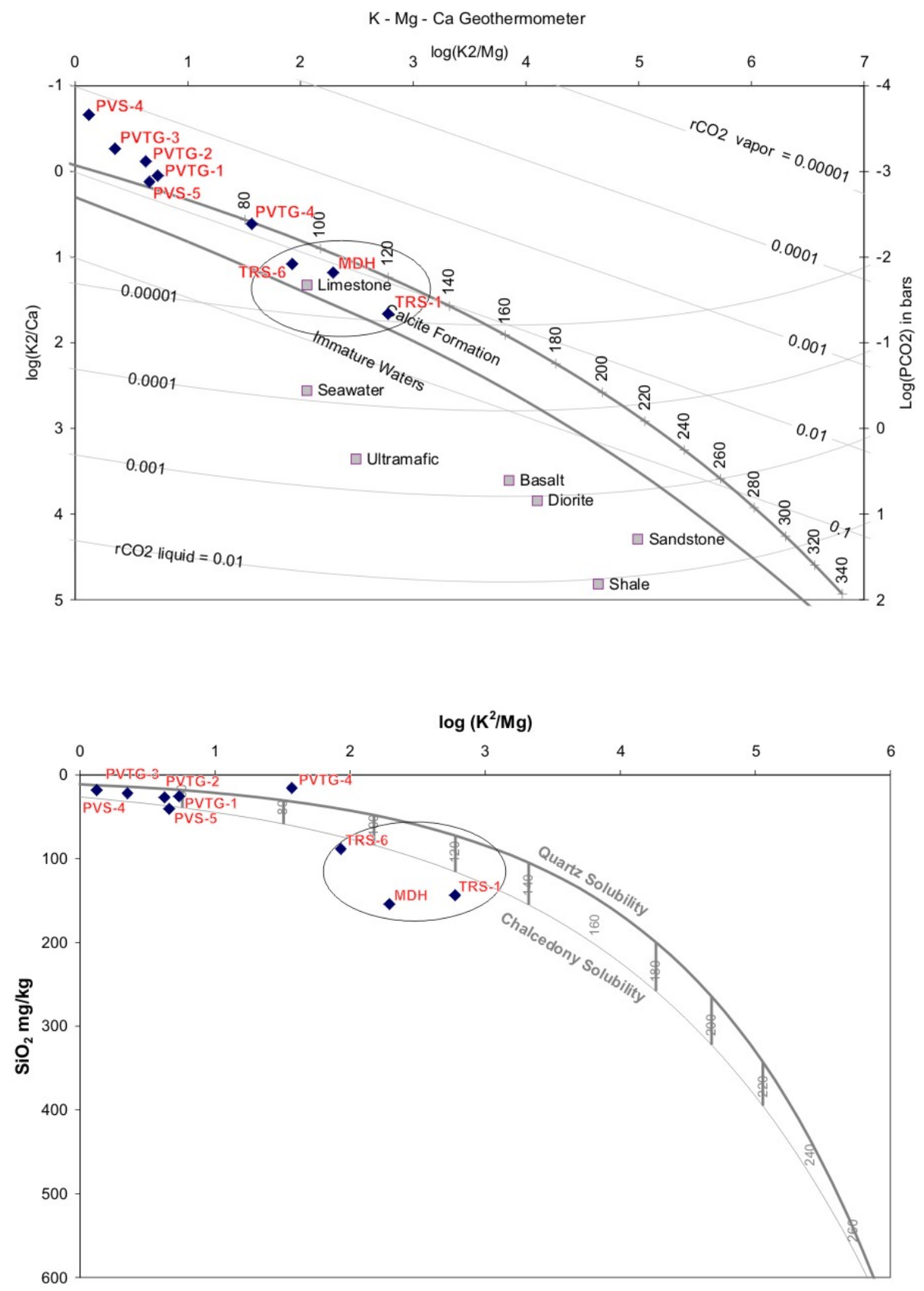

Fairbank Engineering Ltd. 


\section{Diagrams: XClHqtz and XSO4Ca}
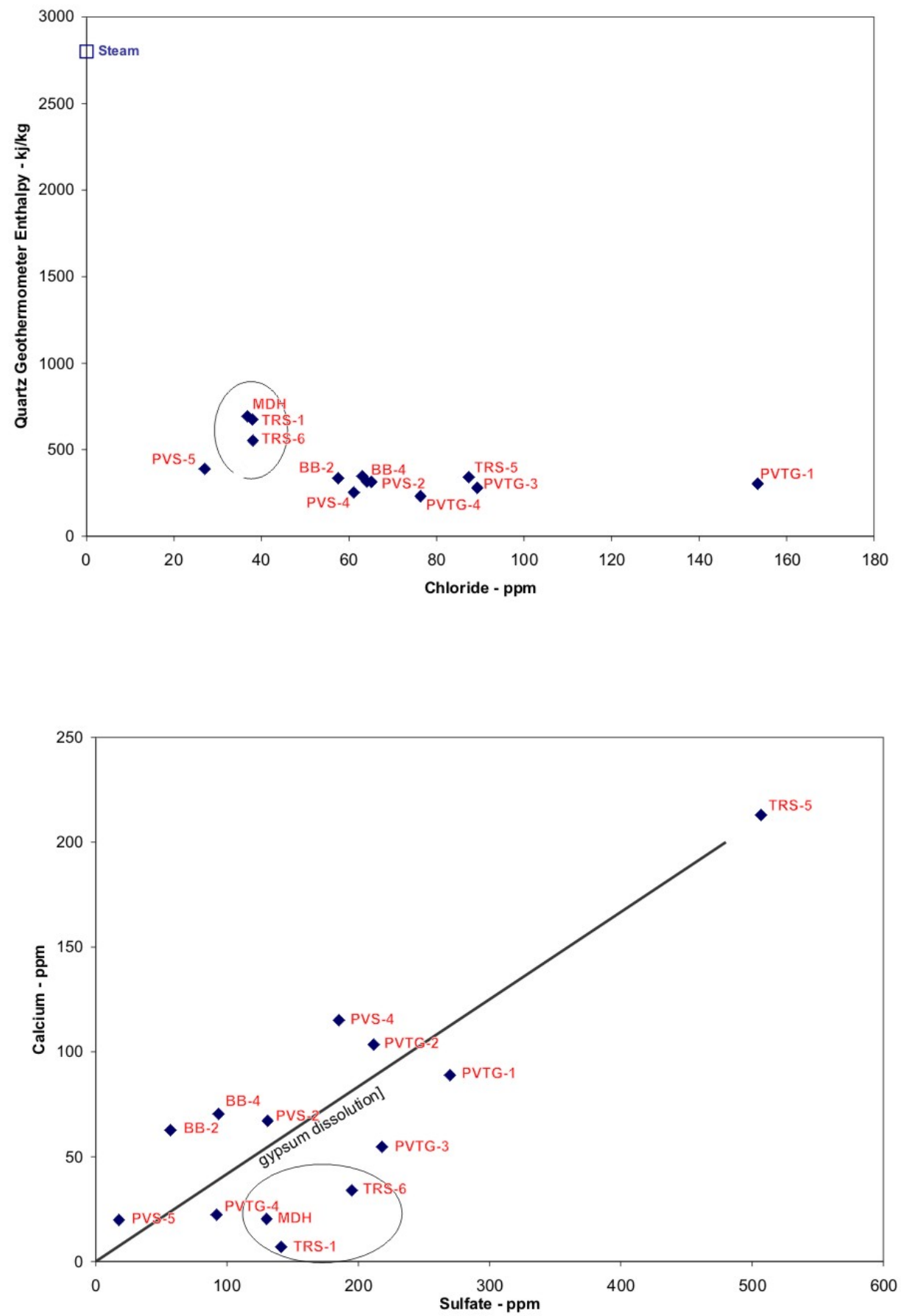

Fairbank Engineering Ltd. 


\section{Diagrams: XCaMg and XClSO4}
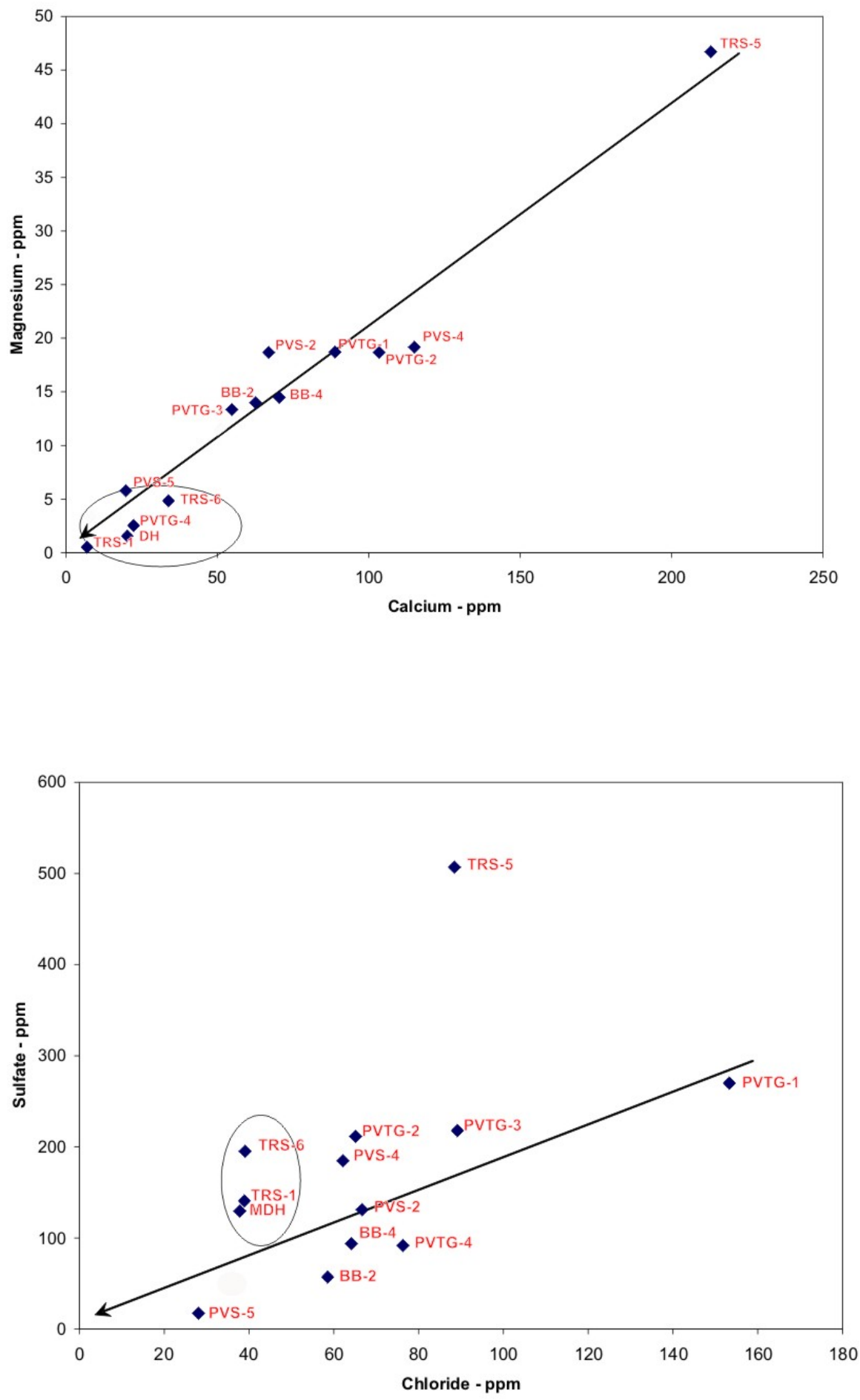

Fairbank Engineering Ltd. 


\section{Diagram: SO4-HCO3-Cl}

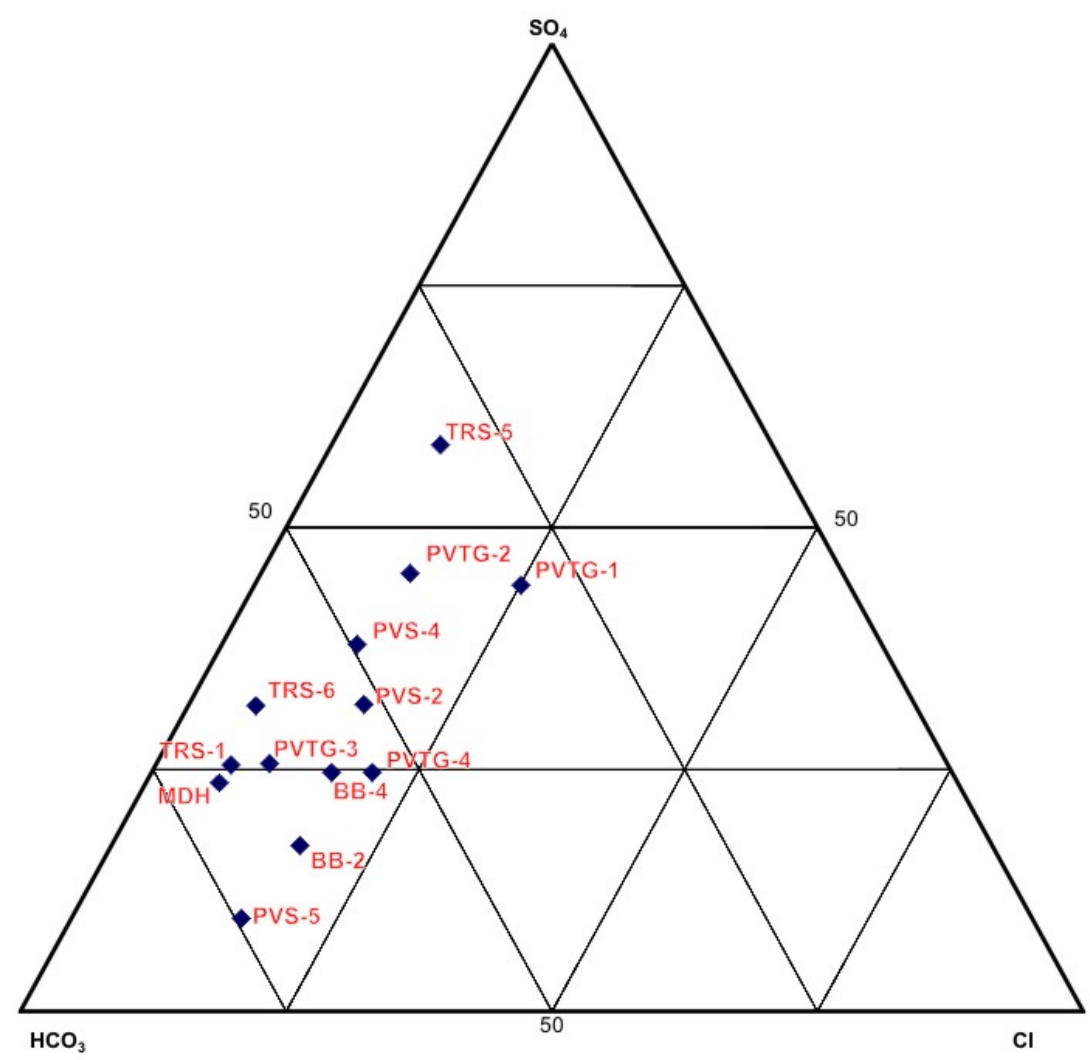




\section{Diagram: Na+K-Ca-Mg}

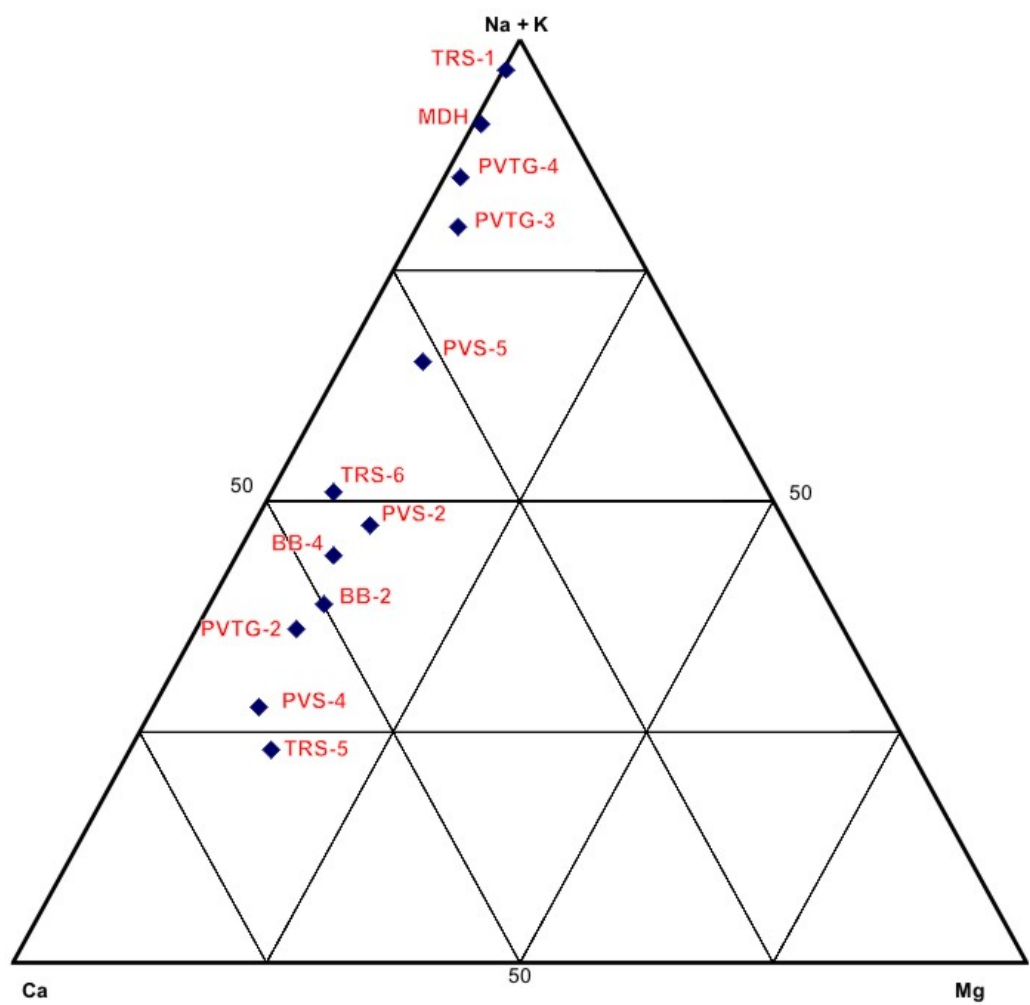

